US Army Corps of Engineers ${ }_{\circledast}$

Engineer Research and

Development Center

\title{
Investigation of Materials for Charleroi Lock and Dam Monongahela River Reconstruction Project
}

Monica A. Ramsey and Cody M. Strack

May 2020

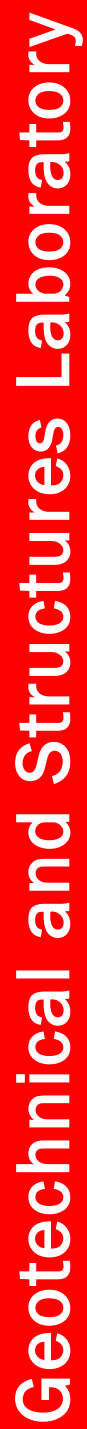

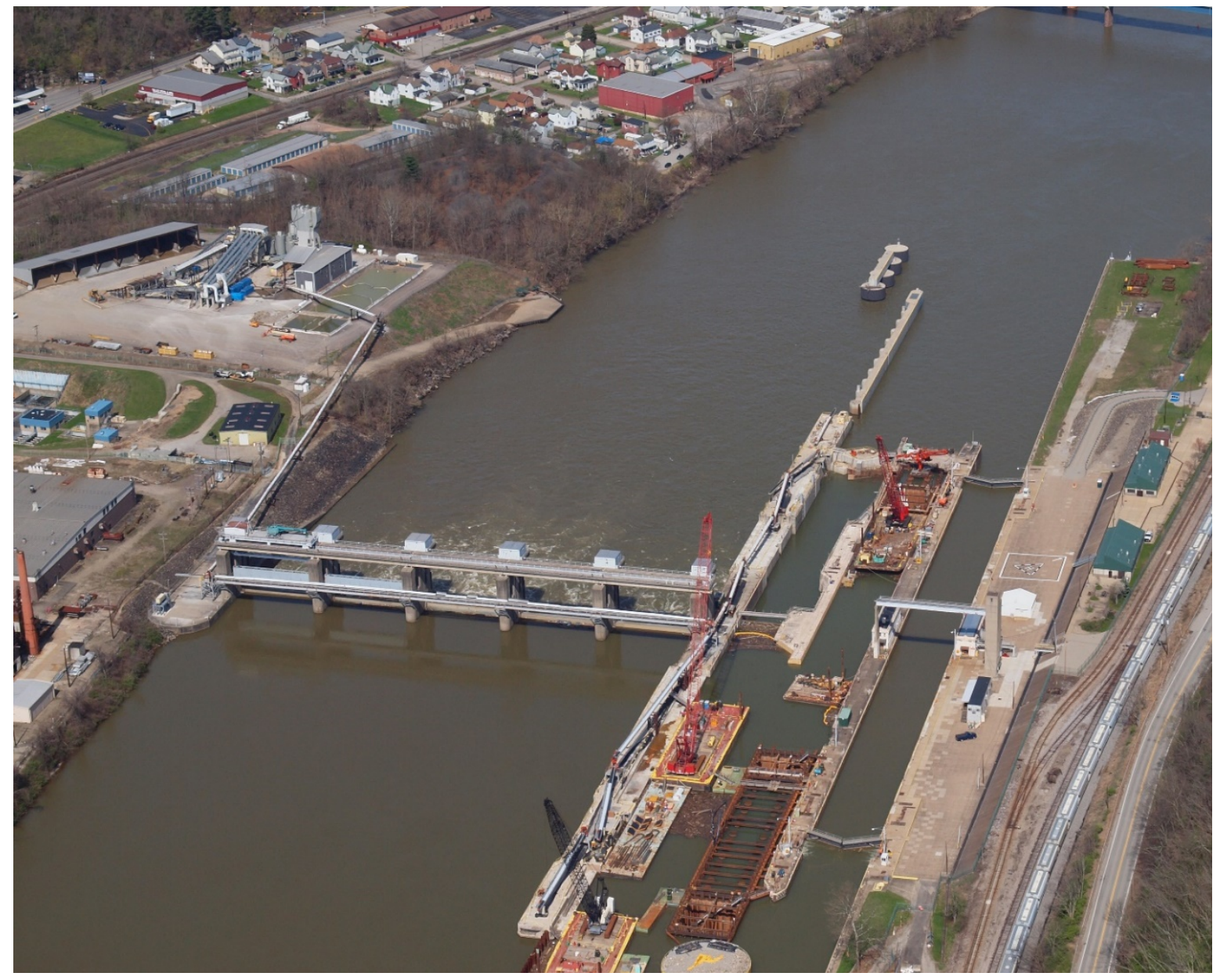

Approved for public release; distribution is unlimited. 
The U.S. Army Engineer Research and Development Center (ERDC) solves the nation's toughest engineering and environmental challenges. ERDC develops innovative solutions in civil and military engineering, geospatial sciences, water resources, and environmental sciences for the Army, the Department of Defense, civilian agencies, and our nation's public good. Find out more at www.erdc.usace.army.mil.

To search for other technical reports published by ERDC, visit the ERDC online library at https://erdclibrary.on.worldcat.org/discovery. 


\section{Investigation of Materials for Charleroi Lock and Dam Monongahela River Reconstruction Project}

Monica A. Ramsey and Cody M. Strack

Geotechnical and Structures Laboratory

U.S. Army Engineer Research and Development Center

3909 Halls Ferry Road

Vicksburg, MS 39180-6199

Final report

Approved for public release; distribution is unlimited.

Prepared for U.S. Army Corps of Engineers Pittsburgh District

Pittsburgh, PA 15222

Under MIPR W81ET491842462, Lower Monongahela River Navigation System Feasibility Study 


\section{Abstract}

The investigation described in this report was conducted for the U.S. Army Engineer District, Pittsburgh as part of a preliminary investigation of cementitious materials and concrete design pursuant to construction of Charleroi Lock and Dam Monongahela River Reconstruction Project. Local materials provided to the U.S. Army Engineer Research Development Center (ERDC) for testing included three different coarse aggregate gradations, two fine aggregate sources, a type II (MH) cement, four fly ash sources, a slag cement, a silica fume, a limestone powder, five admixtures, and two water sources. Aggregate tests consisted of sieve analysis, specific gravity, absorption, materials finer than No. 200, organic impurities, soundness, LA abrasion, clay lumps and friable particles, flat and elongated particles, lightweight particles, and petrography. All cementitious, admixtures, and water-source materials were tested for chemical and physical properties based on appropriate specifications. In addition, four mixture proportions developed by the ERDC for this project in 2005 were scaled to determine the early stiffening of mortar, freezing and thawing, and heat of hydration. This report presents the material characteristic results determined by laboratory testing in accordance with American Society for Testing and Materials procedures or regulating specification criteria.

DISCLAIMER: The contents of this report are not to be used for advertising, publication, or promotional purposes. Citation of trade names does not constitute an official endorsement or approval of the use of such commercial products. All product names and trademarks cited are the property of their respective owners. The findings of this report are not to be construed as an official Department of the Army position unless so designated by other authorized documents. 


\section{Contents}

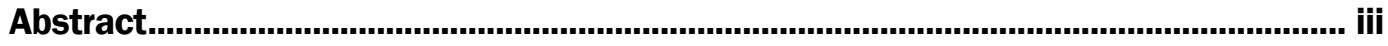

Figures and Tables...................................................................................................................vi

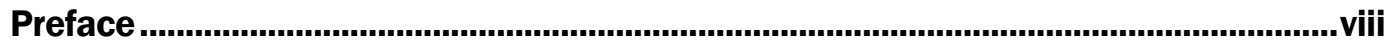

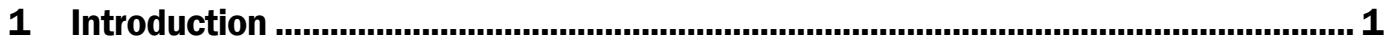

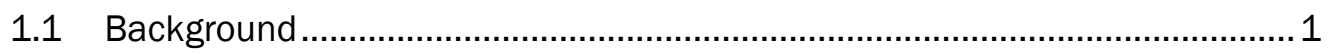

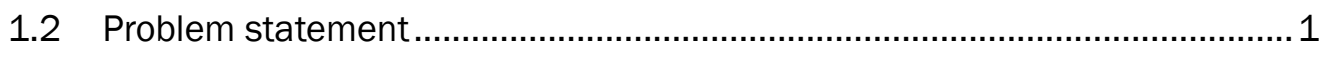

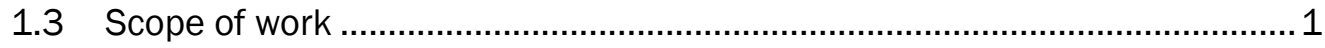

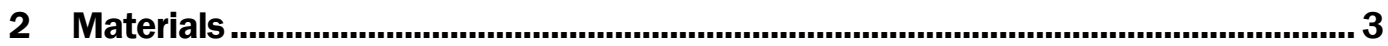

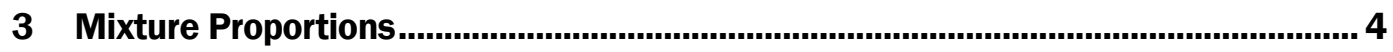

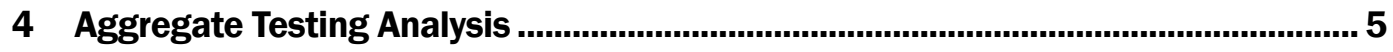

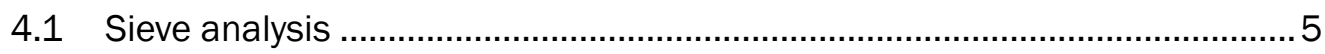

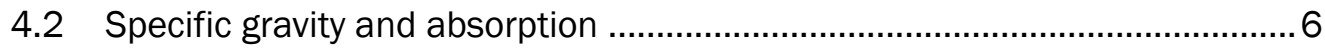

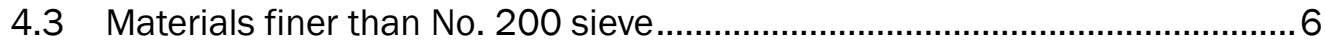

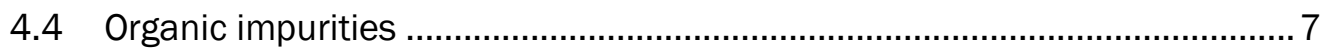

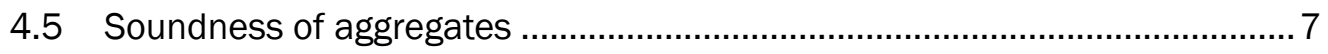

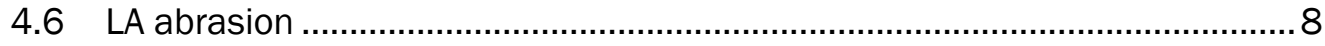

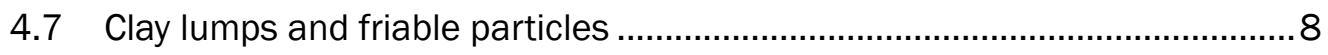

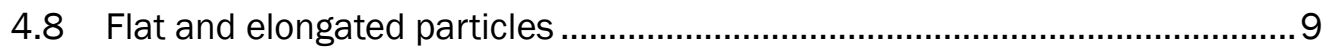

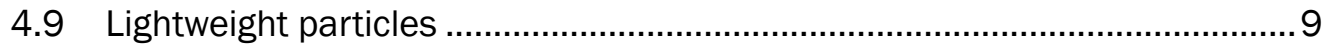

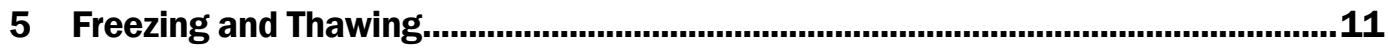

5.1 Mixture proportions and test procedures ................................................11

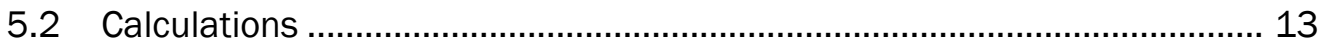

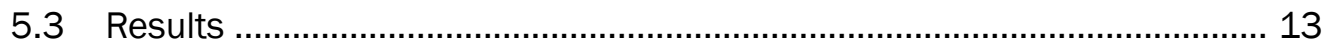

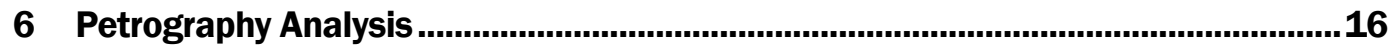

6.1 Hanson aggregate ......................................................................... 17

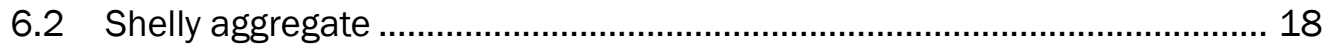

6.3 Georgetown aggregate ................................................................ 19

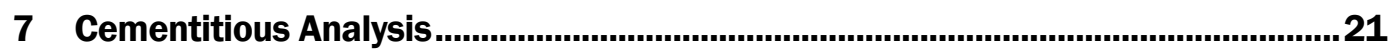

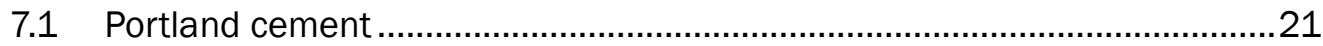

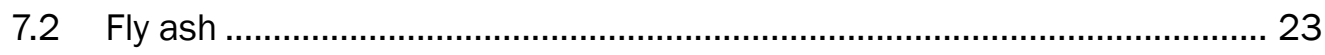

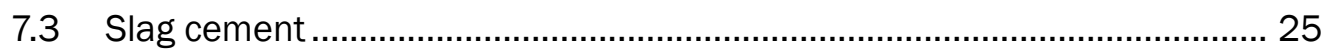

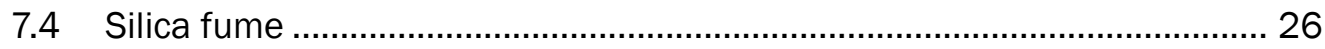

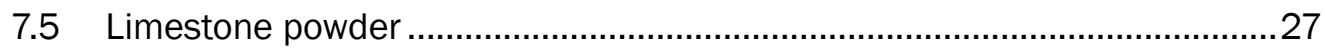

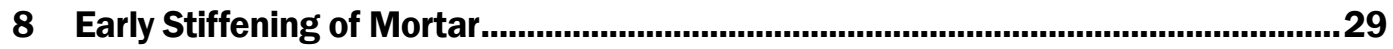




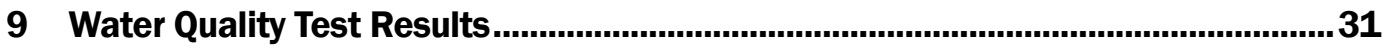

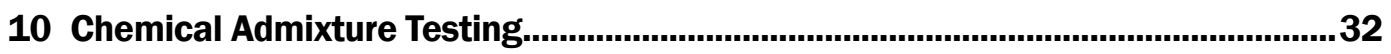

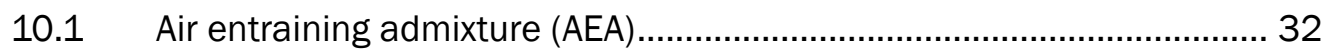

10.2 Retarding (RET) admixture ................................................................ 33

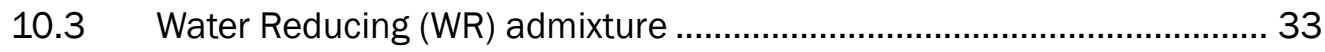

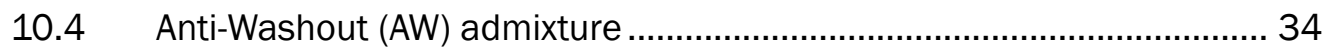

10.5 High Range Water Reducing (HRWR) admixture .................................. 35

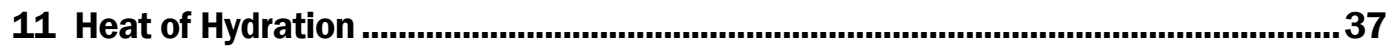

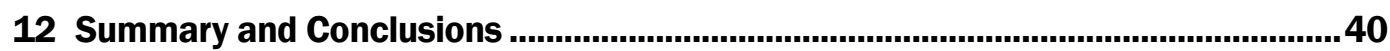

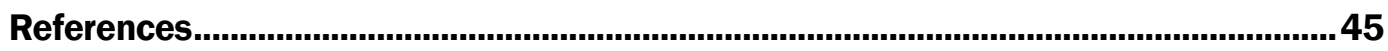

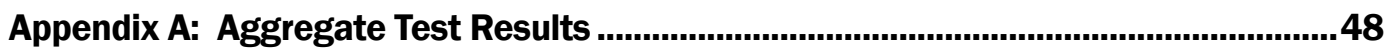

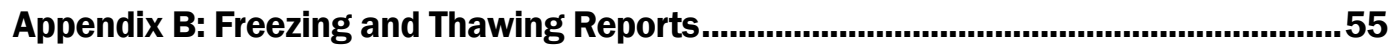

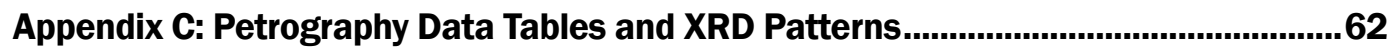

Appendix D: Cementitious Material Reports..........................................................68

Appendix E: Admixture Reports ............................................................................... 75

Appendix F: Water Quality Test Reports ..............................................................80

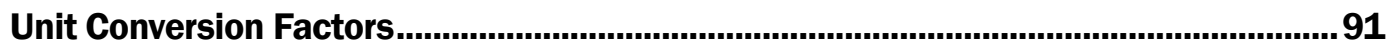

Report Documentation Page 


\section{Figures and Tables}

\section{Figures}

Figure 1. Durability factor and relative dynamic modulus with respect to number of freezing and thawing cycles.

Figure 2. Photomicrographs of different sieve sizes for Hanson aggregate.

Figure 3. Photomicrographs of different sieve sizes for Shelly sand aggregate.

Figure 4. Photomicrographs of different sieve sizes for Georgetown sand aggregate.

Figure 5. Visible settled solids in well water sample from left bank batch plant area

Figure 6 . Heat of hydration for mix $1,5,7$, and 10 by fly ash at 7 and 28 days

Figure C1. XRD pattern for Hanson with calculated weight percentages from whole pattern fitting.

Figure C2. XRD pattern for Shelly with calculated weight percentages from whole pattern fitting.

Figure C3. XRD pattern for Georgetown with calculated weight percentages from whole pattern fitting.

\section{Tables}

Table 1. Standard test methods used for materials tests. .................................................. 2

Table 2. Materials for Charleroi L\&D material testing........................................................... 3

Table 3. Concrete mixture designs for Charleroi L\&D........................................................ 4

Table 4. Sieve analysis results of fine and coarse aggregates. ......................................... 5

Table 5. Bulk specific gravity and absorption results of fine and coarse

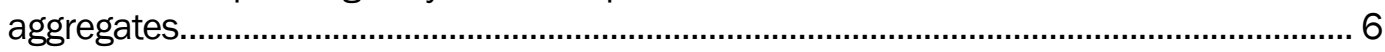

Table 6. Materials finer than No. 200 sieve results by percent.......................................... 7

Table 7. Organic impurities results of fine aggregates......................................................... 7

Table 8. Soundness of aggregates by cumulative percent loss......................................... 8

Table 9. LA abrasion and impact results by percent of sample.......................................... 8

Table 10. Clay lumps and friable particles in aggregate results.......................................... 9

Table 11. Flat and elongated particle results by percent of sample.................................. 9

Table 12. Lightweight particles in fine and coarse aggregates results............................... 10

Table 13. Concrete mixture proportions for freezing and thawing specimens................... 11

Table 14. Freezing and thawing final results. ................................................................ 14

Table 15. Armstrong cement tested in accordance to ASTM C150.................................2 22

Table 16. Fly ash results tested in accordance to ASTM C618............................................. 23

Table 17. Argos-Essroc slag, grade 100 results tested in accordance to ASTM c989. 
Table 18. Elkem grade 970D silica fume results tested in accordance to ASTM

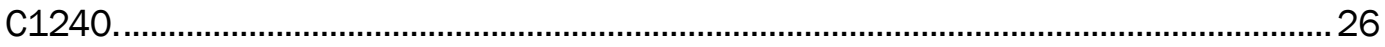

Table 19. Limestone powder analysis summary results. .................................................28

Table 20. Early stiffening of Mix 1, 5, 7, and 10 tested in accordance to ASTM

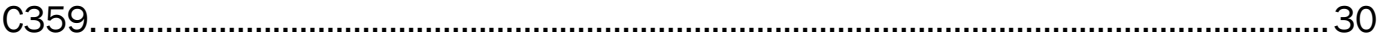

Table 21. Compressive strength results comparing control and AEA-92 concrete.............32

Table 22. Water content, compressive strength, and time of setting results comparing control and Eucon RET-75 admixture in concrete.

Table 23. Water content, compressive strength, and time of setting results comparing control and Eucon WR admixture in concrete.

Table 24. Compressive strength and time of setting results of comparing control and Eucon AWA in concrete.

Table 25. Water content, compressive strength, and time of setting results comparing control and Eucon 37 admixture in concrete. 36

Table 26. Batch quantities for heat of hydration in accordance to ASTM C1702.............. 37

Table 27. Average heat of hydration results at 7 and 28 days...........................................38

Table C1. Data table used in preparation of ASTM C-295 for the Hanson aggregate.

Table C2. Data table used in preparation of ASTM C-295 for the Shelley Sand aggregate.

Table C3. Data table used in preparation of ASTM C-295 for the Georgetown aggregate. 


\section{Preface}

This study was conducted by U.S. Army Engineer Research and Development Center (ERDC) for the Corps of Engineers Pittsburgh District in Pittsburgh, PA, for Charleroi Lock Reconstruction project. The MIPR was W81ET491842462, Lower Monongahela River Navigation System Feasibility Study. The Pittsburgh District technical manager was Mr. Glenn W. Bush Jr.

The work was performed by the Concrete and Materials Branch (GMC) of the Engineering Systems and Materials Division (GM), U.S. Army Engineer Research and Development Center, Geotechnical and Structures Laboratory (ERDC-GSL). At the time of publication, Mr. Christopher M. Moore was Chief, GMC; Mr. Justin S. Strickler was Chief, GM; and Mr. R. Nicholas Boone, GZT, was the Technical Director for Force Projection and Maneuver Support. The Deputy Director of the ERDC GSL was Mr. Charles W. Ertle, and the Director was Mr. Bartley P. Durst.

COL Teresa A. Schlosser was the Commander of ERDC, and Dr. David W. Pittman was the Director. 


\section{Introduction}

\subsection{Background}

The baseline design for the Charleroi Locks originated in 1991 from the Lower Monongahela River Navigation System Feasibility Study. The feasibility study evaluated the ability of Locks and Dams 2, 3, and 4 of the Monongahela River Navigation System to serve navigation interests through the year 2050. The conclusion of the study was to implement a "2 for 3 " replacement known as "The Lower Mon Project."

The Lower Mon Project consists of (a) replacement of the fixed-crest dam at Locks and Dam 2 with a gated dam to be renamed the Braddock Locks and Dam, (b) construction of twin 84-ft x 720-ft locks at Locks and Dam 4 to be renamed the Charleroi Locks and Dam, (c) removal of Locks and Dam 3 at Elizabeth; navigation dredging, and (d) relocation of adversely impacted public facilities. The combination of these features will allow for one 30.3-mile navigation pool between Braddock Locks and Dam and the Charleroi Locks and Dam.

\subsection{Problem statement}

The Charleroi Lock reconstruction began in 2002 with site development and has continued as funding has become available. The project uses government-designed concrete mixes developed in 2005 by the U.S. Army Engineer Waterways Experiment Station, later the Engineer Research and Development Center, in Vicksburg, MS, and produced at the left bank batch plant, a government-owned, contractor-operated batch plant located across the river from the lock chambers. However, original material reports were outdated, and there was no guarantee that the source materials were still capable of meeting project requirements. All cementitious and aggregate materials required retesting to appropriate specifications to ensure quality assurance for all proposed construction materials.

\subsection{Scope of work}

The objective of this study was to evaluate the properties of the materials proposed for use in the rehabilitation of the Charleroi Lock and Dam (L\&D) Monongahela River in accordance to the standard test designations listed in Table 1. 
Table 1. Standard test methods used for materials tests.

\begin{tabular}{|c|c|c|}
\hline $\begin{array}{l}\text { ASTM } \\
\text { Designation }\end{array}$ & Description & Material \\
\hline C 136 & Standard Test Method for Sieve Analysis of Fine and Coarse Aggregates & $\begin{array}{l}3 \text { Coarse Aggregates } \\
2 \text { Fine Aggregates }\end{array}$ \\
\hline C 127 & $\begin{array}{l}\text { Standard Test Method for Relative Density (Specific Gravity) and } \\
\text { Absorption of Coarse Aggregate }\end{array}$ & 3 Coarse Aggregates \\
\hline C 128 & $\begin{array}{c}\text { Standard Test Method for Relative Density (Specific Gravity) and } \\
\text { Absorption of Fine Aggregate }\end{array}$ & 2 Fine Aggregates \\
\hline C 117 & Standard Test Method for Materials Finer than (No. 200) Sieve & $\begin{array}{l}3 \text { Coarse Aggregates } \\
2 \text { Fine Aggregates }\end{array}$ \\
\hline C 40 & $\begin{array}{c}\text { Standard Test Method for Organic Impurities in Fine Aggregates for } \\
\text { Concrete }\end{array}$ & 2 Fine Aggregates \\
\hline C 88 & $\begin{array}{l}\text { Standard Test Method for Soundness of Aggregates by Use of Sodium } \\
\text { Sulfate or Magnesium Sulfate }\end{array}$ & $\begin{array}{l}3 \text { Coarse Aggregates } \\
2 \text { Fine Aggregates }\end{array}$ \\
\hline C 131 & $\begin{array}{l}\text { Standard Test Method for Resistance to Degradation of Small-Size } \\
\text { Coarse Aggregates by Abrasion and Impact in the Los Angeles Machine }\end{array}$ & 3 Coarse Aggregates \\
\hline C 142 & Standard Test Method for Clay Lumps and Friable Particles in Aggregates & $\begin{array}{l}3 \text { Coarse Aggregates } \\
2 \text { Fine Aggregates }\end{array}$ \\
\hline D 4791 & $\begin{array}{c}\text { Standard Test Method for Flat Particles, Elongated Particles, or Flat and } \\
\text { Elongated Particles in Coarse Aggregate }\end{array}$ & 3 Coarse Aggregates \\
\hline C 123 & Standard Test Method for Lightweight Particles in Aggregate & $\begin{array}{l}3 \text { Coarse Aggregates } \\
2 \text { Fine Aggregates }\end{array}$ \\
\hline C 666 & $\begin{array}{c}\text { Standard Test Method for Resistance of Concrete to Rapid Freezing } \\
\text { and Thawing }\end{array}$ & $\begin{array}{l}1 \text { Coarse Aggregate } \\
2 \text { Fine Aggregates } \\
1 \text { Mixture Design }\end{array}$ \\
\hline C 1271 & $\begin{array}{l}\text { Standard Test Method for X-ray Spectrometric Analysis of Lime and } \\
\text { Limestone }\end{array}$ & $\begin{array}{l}1 \text { Limestone Powder } \\
\text { Source }\end{array}$ \\
\hline D 546 & $\begin{array}{l}\text { Standard Test Method for Sieve Analysis of Mineral Filler for Asphalt } \\
\text { Paving Mixtures }\end{array}$ & $\begin{array}{l}1 \text { Limestone Powder } \\
\text { Source }\end{array}$ \\
\hline C 295 & $\begin{array}{l}\text { Standard Practices for Petrographic Examination of Aggregates for } \\
\text { Concrete }\end{array}$ & $\begin{array}{l}3 \text { Coarse Aggregates } \\
2 \text { Fine Aggregates }\end{array}$ \\
\hline C 150 & Standard Specification for Portland Cement & $\begin{array}{l}1 \text { Type II(MH) Cement } \\
\text { Source }\end{array}$ \\
\hline C 359 & Standard Test Method for Early Stiffening of Hydraulic Cement & 4 Mixture Designs \\
\hline C 618 & $\begin{array}{l}\text { Standard Specification for Coal Fly Ash and Raw or Calcined Natural } \\
\text { Pozzolan for Use in Concrete }\end{array}$ & 4 Fly Ash Sources \\
\hline C 989 & Standard Specification for Slag Cement for Use in Concrete & 1 Slag Source \\
\hline C 1240 & Standard Specification for Silica Fume & 1 Silica Fume Source \\
\hline C 1702 & $\begin{array}{c}\text { Standard Test Method for Measurement of Heat of Hydration Using } \\
\text { Isothermal Conduction Calorimetry }\end{array}$ & 4 Mixture Designs \\
\hline $\begin{array}{l}\text { C } 494 \\
\text { C } 260\end{array}$ & Standard Specification for Chemical Admixtures For Concrete & 5 Admixtures \\
\hline CRD-C 400 & Water for mixing and curing & 2 Water Sources \\
\hline
\end{tabular}




\section{Materials}

Candidate project materials including cements, pozzolans, and aggregates were chosen by the Pittsburgh District. The source materials were marketed in the vicinity of the proposed project location. Table 2 identifies the materials included in this study. ERDC tested all materials in accordance to the ASTM requirements referenced in the table for validation.

Table 2. Materials for Charleroi L\&D material testing.

\begin{tabular}{|c|c|c|c|c|}
\hline Material & Manufacturer & Location & CMB \# & $\begin{array}{c}\text { Testing } \\
\text { Validation }\end{array}$ \\
\hline Type II(MH) Cement & Armstrong & Cabot, PA & 150063 & ASTM C150 \\
\hline \multirow{4}{*}{ Class F Fly Ash } & $\begin{array}{c}\text { Headwaters Resources, } \\
\text { Ft. Martin }\end{array}$ & Maidsville, WV & 150064 & \multirow{4}{*}{ ASTM C618 } \\
\hline & $\begin{array}{c}\text { Headwaters Resources, } \\
\text { W. H. Sammis }\end{array}$ & Stratton, $\mathrm{OH}$ & 150065 & \\
\hline & $\begin{array}{c}\text { Separation } \\
\text { Technologies, Longview }\end{array}$ & Maidsville, WV & 180005 & \\
\hline & $\begin{array}{c}\text { Separation } \\
\text { Technologies, Brandon } \\
\text { Shores }\end{array}$ & Curtis Bay, MD & 180018 & \\
\hline Slag Cement, Grade 100 & Argos-Essroc-Lehigh & Middlebranch, $\mathrm{OH}$ & 150066 & ASTM C989 \\
\hline Limestone Powder & Graymont & Bellefonte, PA & 150067 & $\begin{array}{l}\text { ASTM C1271 } \\
\text { ASTM D546 } \\
\text { ASTM D242 }\end{array}$ \\
\hline Silica Fume & Elkem Materials & Pittsburgh, PA & 150068 & ASTM C1240 \\
\hline 3/4-inch Coarse Aggregate & \multirow{3}{*}{ Hanson Quarry } & \multirow{3}{*}{ Connellsville, PA } & 150070 & \multirow{5}{*}{$\begin{array}{c}\text { ASTM C40 } \\
\text { ASTM C88 } \\
\text { ASTM C117 } \\
\text { ASTM } \\
\text { C127/128 } \\
\text { ASTM C131 } \\
\text { ASTM C136 } \\
\text { ASTM C142 } \\
\text { ASTM D4791 } \\
\text { ASTM C123 }\end{array}$} \\
\hline $\begin{array}{l}11 / 2 \text {-inch Coarse } \\
\text { Aggregate }\end{array}$ & & & 150071 & \\
\hline 3-inch Coarse Aggregate & & & 150072 & \\
\hline \multirow{2}{*}{ Fine Aggregates } & Georgetown & Georgetown, PA & 150069 & \\
\hline & Shelly & Reedsville, $\mathrm{OH}$ & 160004 & \\
\hline AEA-92 Admixture & \multirow{5}{*}{ Euclid } & \multirow{5}{*}{ Cleveland, $\mathrm{OH}$} & 150073 & \multirow{5}{*}{ ASTM C494 } \\
\hline Retarder 75 Admixture & & & 150074 & \\
\hline WR Admixture & & & 150075 & \\
\hline AW Admixture & & & 150076 & \\
\hline HRWR Admixture, 37 & & & 150077 & \\
\hline Municipal Water & - & $\begin{array}{l}\text { Charleroi Municipal } \\
\text { Water Authority }\end{array}$ & 150088 & CRD-C 400 \\
\hline Well Water & - & Left Bank Batch Plant & 150089 & CRD-C 400 \\
\hline
\end{tabular}




\section{Mixture Proportions}

The composition of the concrete mixture proportions developed by ERDC for the Pittsburgh District in 2005 named Mix 1, Mix 5, Mix 7, and Mix 10 are detailed in Table 3. Certain test methods presented in this report including the early stiffening of mortar, freezing and thawing, and heat of hydration testing scaled batch proportions based on these mixture proportions.

Table 3. Concrete mixture designs for Charleroi L\&D.

\begin{tabular}{|c|c|c|c|c|}
\hline \multirow[b]{3}{*}{ Material } & \multicolumn{4}{|c|}{ Batch Quantities } \\
\hline & Mix 1 & Mix 5 & Mix 7 & Mix 10 \\
\hline & $\begin{array}{c}\text { Typical Shaft } \\
\text { Tremie Concrete }\end{array}$ & $\begin{array}{l}\text { Interior Mass } \\
\text { Concrete }\end{array}$ & $\begin{array}{l}\text { Exterior Mass } \\
\text { Concrete }\end{array}$ & $\begin{array}{l}\text { General Purpose } \\
\text { Concrete }\end{array}$ \\
\hline Cement $(\mathrm{lb} / \mathrm{yd})$ & 167 & 191 & 253 & 495 \\
\hline Class F Fly Ash (lb/yd) & 158 & 75 & 139 & 165 \\
\hline GGBFS (Ib/yd) & 367 & 87 & 69 & 0 \\
\hline Silica Fume (lb/yd) & 29 & 0 & 0 & 0 \\
\hline Limestone Powder (Ib/yd) & 155 & 0 & 0 & 0 \\
\hline $\begin{array}{l}\text { 3/4-in. Coarse Aggregate } \\
(\mathrm{lb} / \mathrm{yd})\end{array}$ & 1,323 & 739 & 1,129 & 1,720 \\
\hline $\begin{array}{l}\text { 1/12-in. Coarse Aggregate } \\
(\mathrm{lb} / \mathrm{yd})\end{array}$ & 0 & 747 & 935 & 0 \\
\hline $\begin{array}{l}\text { 3-in. Coarse Aggregate } \\
\text { (lb/yd) }\end{array}$ & 0 & 1,000 & 0 & 0 \\
\hline Fine Aggregate $(\mathrm{lb} / \mathrm{yd})$ & 1,409 & 958 & 1,141 & 1,239 \\
\hline Potable Water (lb/yd) & 303 & 183 & 213 & 258 \\
\hline $\begin{array}{l}\text { Air Entraining Admixture } \\
\text { (fl oz/yd) }\end{array}$ & 0 & 8 & 16 & 7 \\
\hline $\begin{array}{l}\text { Water Reducing Admixture } \\
\text { (fl oz/yd) }\end{array}$ & 0 & 0 & 0 & 0 \\
\hline $\begin{array}{l}\text { High Range Water } \\
\text { Reducing Admixture } \\
\text { (fl oz/yd) }\end{array}$ & 138.1 & 0 & 0 & 12 \\
\hline $\begin{array}{l}\text { Retarding Admixture } \\
\text { (fl oz/yd) }\end{array}$ & 30.1 & 7 & 7 & 7 \\
\hline $\begin{array}{l}\text { Anti-Washout Admixture } \\
\text { (fl oz/yd) }\end{array}$ & 97.2 & 0 & 0 & 0 \\
\hline
\end{tabular}




\section{Aggregate Testing Analysis}

Two sources of natural sand and three gradations of limestone coarse aggregates were tested in accordance with ASTM procedures presented in this section. Aggregate quality requirements were based on the Charleroi construction specifications (USACE Pittsburgh District 2015). Further aggregate report details can be found in Appendix A.

\subsection{Sieve analysis}

The gradation results for aggregates tested in accordance to ASTM C136 (ASTM 2016c) are presented in Table 4.

Table 4. Sieve analysis results of fine and coarse aggregates.

\begin{tabular}{|c|c|c|c|c|c|c|c|c|c|c|}
\hline \multirow{3}{*}{$\begin{array}{l}\text { Nominal } \\
\text { Size } \\
\text { (Sieves } \\
\text { with } \\
\text { Square } \\
\text { Openings) }\end{array}$} & \multicolumn{10}{|c|}{ Gradations of aggregates by cumulative \% passing } \\
\hline & \multicolumn{2}{|c|}{$\begin{array}{l}\text { Hanson Quarry } \\
\text { 3-inch Aggregate }\end{array}$} & \multicolumn{2}{|c|}{$\begin{array}{l}\text { Hanson Quarry } \\
\text { 11/2-inch Aggregate }\end{array}$} & \multicolumn{2}{|c|}{$\begin{array}{l}\text { Hanson Quarry } \\
\text { 3/4-inch Aggregate }\end{array}$} & \multicolumn{2}{|c|}{$\begin{array}{l}\text { Georgetown } \\
\text { Natural Sand }\end{array}$} & \multicolumn{2}{|c|}{$\begin{array}{c}\text { Shelley } \\
\text { Natural Sand }\end{array}$} \\
\hline & $\begin{array}{c}\text { Test } \\
\text { Results }\end{array}$ & $\begin{array}{c}\text { Charleroi } \\
\text { Spec. } \\
\text { Limits }\end{array}$ & $\begin{array}{c}\text { Test } \\
\text { Results }\end{array}$ & $\begin{array}{c}\text { Charleroi } \\
\text { Spec. } \\
\text { Limits }\end{array}$ & $\begin{array}{c}\text { Test } \\
\text { Results }\end{array}$ & $\begin{array}{c}\text { Charleroi } \\
\text { Spec. } \\
\text { Limits }\end{array}$ & $\begin{array}{c}\text { Test } \\
\text { Results }\end{array}$ & $\begin{array}{c}\text { Charleroi } \\
\text { Spec. } \\
\text { Limits }\end{array}$ & $\begin{array}{c}\text { Test } \\
\text { Results }\end{array}$ & $\begin{array}{c}\text { Charleroi } \\
\text { Spec. } \\
\text { Limits }\end{array}$ \\
\hline 4-in. & 100 & 100 & - & - & - & - & & - & & - \\
\hline 3-in. & 92 & $90-100$ & - & - & - & - & & - & & - \\
\hline 21/2-in. & 66 & - & - & - & - & - & - & - & - & - \\
\hline 2-in. & 20 & $20-55$ & 100 & 100 & - & - & - & - & - & - \\
\hline 11/2-in. & 1 & $0-10$ & 83 & $90-100$ & - & - & - & - & - & - \\
\hline 1-in. & 0 & $0-5$ & 16 & $20-45$ & 100 & 100 & - & - & - & - \\
\hline 3/4-in. & 0 & - & 3 & $0-10$ & 97 & $90-100$ & - & - & - & - \\
\hline 1/2-in. & - & - & - & - & 46 & - & - & - & - & - \\
\hline 3/8-in. & - & - & 0 & $0-5$ & 17 & $20-55$ & 100 & 100 & 100 & 100 \\
\hline No. 4 & - & - & - & - & 4 & $0-10$ & 98 & $95-100$ & 99 & $95-100$ \\
\hline No. 8 & - & - & - & - & 1 & $0-5$ & 86 & $80-95$ & 88 & $80-95$ \\
\hline No. 16 & - & - & - & - & - & - & 74 & $60-80$ & 77 & $60-80$ \\
\hline No. 30 & - & - & - & - & - & - & 55 & $35-60$ & 57 & $35-60$ \\
\hline No. 40 & - & - & - & - & - & - & 33 & - & 30 & - \\
\hline No. 50 & - & - & - & - & - & - & 14 & $15-30$ & 12 & $15-30$ \\
\hline No. 100 & - & - & - & - & - & - & 2 & $5-10$ & 2 & $5-10$ \\
\hline No. 200 & - & - & - & - & - & - & 0 & $0-3$ & 0 & $0-3$ \\
\hline
\end{tabular}


The coarse and fine aggregates met all grading requirements with the following exceptions:

- The Georgetown natural sand resulted in $14 \%$ passing the \#50 sieve (15-30\% criteria) and $2 \%$ passing the \#100 sieve (5-10\% criteria).

- The Shelly natural sand resulted in $12 \%$ passing the \#50 sieve $(15-30 \%$ criteria) and $2 \%$ passing the \#100 sieve (5-10\% criteria).

- The $1^{1 / 2}$-in. Hanson aggregate resulted in $83 \%$ passing the $1^{1 / 2}$-in. sieve (90 to $100 \%$ criteria) and $16 \%$ passing the 1 -in. sieve (20 to $55 \%$ criteria).

- The $3 / 4-i n$. Hanson aggregate resulted in $17 \%$ passing the $3 / 8$-in. sieve (20 to $55 \%$ criteria).

\subsection{Specific gravity and absorption}

The bulk specific gravity at the saturated, surface-dry condition and absorption for the coarse and fine aggregates were tested in accordance with ASTM C127 (ASTM 2015a) and C128 (ASTM 2015b), respectively. Specific gravity and absorption results are provided in Table 5 . All aggregates met the limiting criteria of specific gravity (minimum 2.55 for fine aggregates and 2.63 for coarse aggregates) and absorption (maximum $2 \%$ for fine aggregates and $3 \%$ coarse aggregates) as defined in project specifications.

Table 5. Bulk specific gravity and absorption results of fine and coarse aggregates.

\begin{tabular}{|c|l|l|l|l|l|}
\hline \multicolumn{1}{|c|}{ Property } & \multicolumn{1}{|c|}{$\begin{array}{c}\text { Hanson } \\
\text { 3-in. }\end{array}$} & $\begin{array}{c}\text { Hanson } \\
11 / 2 \text {-in. }\end{array}$ & $\begin{array}{c}\text { Hanson } \\
\text { 3/4-in. }\end{array}$ & $\begin{array}{c}\text { Georgetown } \\
\text { Sand }\end{array}$ & \multicolumn{1}{|c|}{$\begin{array}{c}\text { Shelley } \\
\text { Sand }\end{array}$} \\
\hline $\begin{array}{l}\text { Bulk specific } \\
\text { gravity (SSD) }\end{array}$ & 2.69 & 2.68 & 2.67 & 2.62 & 2.60 \\
\hline Absorption, \% & 0.42 & 0.44 & 0.61 & 1.4 & 1.7 \\
\hline
\end{tabular}

\subsection{Materials finer than No. 200 sieve}

The amount of material finer than a No. 200 sieve by washing was determined in accordance to ASTM C117 (ASTM 2017a). Procedure A (water only) was used to disperse clay and other particles from the aggregates during the test. The results of the percentage of the material finer than the No. 200 sieve contained in the fine aggregate are provided in Table 6 . The limiting criteria based on project specifications is $3 \%$ maximum for fine aggregates and $1 \%$ maximum for coarse aggregates. The Hanson $1 \frac{1}{2}$ - and 3 -in. coarse aggregates exceeded this criteria with $1.05 \%$ and $1.01 \%$, respectively. 
Table 6. Materials finer than No. 200 sieve results by percent.

\begin{tabular}{|c|c|}
\hline Aggregate & Percent finer than No. 200 sieve \\
\hline Hanson 3/4-in. Aggregate & 0.73 \\
\hline Hanson 11/2-in. Aggregate & 1.05 \\
\hline Hanson 3-in. Aggregate & 1.05 \\
\hline Shelley Sand & 0.6 \\
\hline Georgetown Sand & 0.9 \\
\hline
\end{tabular}

\subsection{Organic impurities}

Fine aggregates were tested in accordance with ASTM C40 (ASTM 2016b) to quantify if injurious amounts of organic impurities are present in the aggregate sample. This test procedure exposes material to a sodium hydroxide solution $(\mathrm{NaOH})$ that releases color, which is then compared to five glass color standards. The five color standards correlate to an organic plate No. 1-5 with 3 being the standard. If a sample is darker than the standard color, i.e. No. 3, the fine aggregate is considered to possibly contain injurious organic impurities. The organic plate No. results shown in Table 7 indicate that both sands do not contain organic impurities at a concentration great enough to warrant further testing at this time.

Table 7. Organic impurities results of fine aggregates.

\begin{tabular}{|c|c|}
\hline Aggregate & Organic Plate No. \\
\hline Shelly Sand & 2 \\
\hline Georgetown Sand & 2 \\
\hline
\end{tabular}

\subsection{Soundness of aggregates}

The preliminary estimate of the soundness of aggregates proposed for project usage were tested in accordance to ASTM C88 (ASTM 2018b). Aggregates were immersed in a magnesium sulfate solution to simulate severe weathering conditions. The maximum allowable limits for soundness suggested in ASTM C33 (ASTM 2016a) is 18\% for all weathering conditions. Cumulative percent loss results given in Table 8 reveal all aggregates fall below this criteria. 
Table 8. Soundness of aggregates by cumulative percent loss.

\begin{tabular}{|c|c|}
\hline Aggregate & Cumulative percent loss \\
\hline Hanson 3/4-in. Aggregate & 1.2 \\
\hline Hanson 11/2-in. Aggregate & 5.3 \\
\hline Hanson 3-in. Aggregate & 0.5 \\
\hline Shelley Sand & 10.6 \\
\hline Georgetown Sand & 8.2 \\
\hline
\end{tabular}

\subsection{LA abrasion}

The resistance to degradation of small-size coarse aggregates by abrasion was tested in accordance to ASTM C131 (ASTM 2014a). This method uses a Los Angeles (LA) machine to expose aggregates to a combination of actions including abrasion, impact, and grinding in a rotating steel drum that contains a specified number of steel spheres. The drum rotates at a constant rate while the shelf inside the drum picks up the sample and steel spheres and drops them. Five hundred revolutions of the testing machine were used. Loss by abrasion and impact is reported by percent of the sample mass in Table 9. All aggregates met the abrasion project specification requirement of less than $40 \%$ loss.

Table 9. LA abrasion and impact results by percent of sample.

\begin{tabular}{|c|c|}
\hline Small-Size Coarse Aggregate & Loss (\%) \\
\hline Hanson 3/4-in. Aggregate & 22.1 \\
\hline Hanson 11/2-in. Aggregate & 22.5 \\
\hline Hanson 3-in. Aggregate & 11.6 \\
\hline
\end{tabular}

\subsection{Clay lumps and friable particles}

The approximate determination of clay lumps and friable particles in potential project aggregates were in accordance to ASTM C142 (ASTM 2017c). The percent clay lumps and friable particles reported in Table 10 are less than the limiting criteria (1.2\% for fine aggregate and $2 \%$ for coarse aggregate) given in the project specifications. 
Table 10. Clay lumps and friable particles in aggregate results.

\begin{tabular}{|c|c|}
\hline Aggregate & Clay Lumps and Friable Particles (\%) \\
\hline Hanson 3/4-in. Aggregate & 0.1 \\
\hline Hanson 11/2-in. Aggregate & 0.1 \\
\hline Hanson 3-in. Aggregate & 0.1 \\
\hline Shelley Sand & 0.3 \\
\hline Georgetown Sand & 0.1 \\
\hline
\end{tabular}

\subsection{Flat and elongated particles}

The percentage of flat particles, elongated particles, or flat and elongated particles in coarse aggregates were tested in accordance to ASTM D4791 (ASTM 2010). The original procedure presented in the standard Method A was used for non-Superpave applications. Individual particles of aggregates of specific sieve sizes were measured with a caliper device set at a 3:1 ratio to determine the ratios of width to thickness, length to width, and length to thickness. The flat and elongated particle results by percent of sample provided in Table 11 are less than the $12 \%$ maximum limiting criteria defined in the project specification.

Table 11. Flat and elongated particle results by percent of sample.

\begin{tabular}{|c|c|}
\hline Aggregate & Percent of Sample \\
\hline Hanson 3/4-in. Aggregate & 0.0 \\
\hline Hanson 11/2-in. Aggregate & 8.0 \\
\hline Hanson 3-in. Aggregate & 9.8 \\
\hline
\end{tabular}

\subsection{Lightweight particles}

The amount of lightweight material in fine and coarse aggregates were tested in accordance with ASTM C123 (ASTM 2017b). Zinc bromide (2.4 specific gravity) was used to determine chert and shale content and zinc chloride (2.0 specific gravity) was used to separate particles that may be classified as coal or lignite. The maximum allowable chert and shale content defined in project specifications is $10 \%$ for fine aggregates and $5 \%$ for coarse aggregates. The maximum allowable coal and lignite particles is $1 \%$ for fine aggregates and $0.5 \%$ for coarse aggregates. The percentage of lightweight particles results are given in Table 12. All 
aggregates met the limiting criteria with the exception of the $1.2 \%$ coal and lignite content in the Georgetown sand.

Table 12. Lightweight particles in fine and coarse aggregates results.

\begin{tabular}{|c|c|c|c|c|c|c|}
\hline \multirow[b]{2}{*}{$\begin{array}{l}\text { Lightweight } \\
\text { Particle }\end{array}$} & \multirow[b]{2}{*}{ Heavy Liquid } & \multicolumn{5}{|c|}{ Aggregate } \\
\hline & & $\begin{array}{l}\text { Shelley } \\
\text { Sand }\end{array}$ & $\begin{array}{l}\text { Georgetown } \\
\text { Sand }\end{array}$ & $\begin{array}{l}\text { Hanson } \\
\text { 3/4-inch }\end{array}$ & $\begin{array}{l}\text { Hanson } \\
\text { 11/2-in. } \\
\text { Aggregate }\end{array}$ & $\begin{array}{l}\text { Hanson } \\
\text { 3-in. } \\
\text { Aggregate }\end{array}$ \\
\hline $\begin{array}{c}\text { Chert and } \\
\text { Shale }\end{array}$ & $\begin{array}{c}\text { Zinc } \\
\text { Bromide } \\
\text { (2.4 Specific } \\
\text { Gravity) }\end{array}$ & 1.1 & 1.2 & 1.5 & 0.4 & 0 \\
\hline $\begin{array}{l}\text { Coal and } \\
\text { Lignite }\end{array}$ & $\begin{array}{c}\text { Zinc } \\
\text { Chloride } \\
\text { (2.0 Specific } \\
\text { Gravity) }\end{array}$ & 0.7 & 1.2 & 0 & 0 & 0 \\
\hline
\end{tabular}




\section{$5 \quad$ Freezing and Thawing}

The freezing and thawing durability of one project coarse aggregate (Hanson), two project natural sand fine aggregates (Shelly and Georgetown), and one project mixture design (Mix 7) were determined in accordance to Procedure A of ASTM C666 (ASTM 2015d). In this method, specimens were frozen in water and cycled between 4 and $-18^{\circ} \mathrm{C}$ in $2-\mathrm{hr}$ intervals until the specimens reached 300 cycles of freezing and thawing. Further report details can be found in Appendix B.

\subsection{Mixture proportions and test procedures}

Freezing and thawing test specimens were prepared from the mixture proportion of materials detailed in Table 13.

Table 13. Concrete mixture proportions for freezing and thawing specimens.

\begin{tabular}{|c|c|c|c|c|c|c|}
\hline & & & \multicolumn{4}{|c|}{ Weight at SSD, (lb/yd³) } \\
\hline $\begin{array}{c}\text { Mixture } \\
\text { Constituent }\end{array}$ & Source & CMB ID & Hanson & Shelly & Georgetown & Mix 7 \\
\hline $\begin{array}{c}\text { Type II(MH) } \\
\text { Cement }\end{array}$ & Armstrong & 150063 & 563 & 563 & 563 & 253 \\
\hline $\begin{array}{c}\text { Class F Fly } \\
\text { Ash }\end{array}$ & $\begin{array}{l}\text { Headwaters } \\
\text { Resources, } \\
\text { Sammis Power } \\
\text { Plant }\end{array}$ & 150065 & - & - & - & 139 \\
\hline Slag Cement & Argos-Essroc & 150066 & - & - & - & 69 \\
\hline \multirow{2}{*}{$\begin{array}{l}\text { Coarse } \\
\text { Aggregate }\end{array}$} & Hanson & 150070 & 1,874 & - & - & 2,064 \\
\hline & $\begin{array}{c}\text { Calera } \\
\text { (Control) }\end{array}$ & 140040 & - & 1,937 & 1,935 & - \\
\hline \multirow{3}{*}{$\begin{array}{c}\text { Fine } \\
\text { Aggregate }\end{array}$} & $\begin{array}{c}\text { Arkadelphia } \\
\text { (Control) }\end{array}$ & 160142 & 1,158 & - & - & - \\
\hline & Shelly & 160004 & - & 1,163 & - & - \\
\hline & Georgetown & 150069 & - & - & 1,160 & 1,141 \\
\hline \multirow{2}{*}{ Admixture } & Eucon AEA 92 & 150073 & $\begin{array}{c}1.8 \\
(\mathrm{fl} \mathrm{oz})\end{array}$ & $\begin{array}{c}2.7 \\
(\mathrm{fl} \mathrm{oz})\end{array}$ & $\begin{array}{c}1.7 \\
(\mathrm{fl} \mathrm{oz})\end{array}$ & $\begin{array}{c}1.4 \\
(\mathrm{fl} \mathrm{oz})\end{array}$ \\
\hline & $\begin{array}{l}\text { Eucon } 75 \\
\text { Retarder }\end{array}$ & 150074 & - & - & - & $\begin{array}{c}0.7 \\
(\mathrm{fl} \mathrm{oz})\end{array}$ \\
\hline \multirow{2}{*}{ Water } & \multicolumn{2}{|c|}{ Vicksburg, MS Municipal } & 276 & 265 & 270 & - \\
\hline & \multicolumn{2}{|c|}{ Charleroi, PN Municipal } & - & - & - & 213 \\
\hline
\end{tabular}


The specimens for the Hanson, Shelley, and Georgetown project aggregates were fabricated by the ERDC under laboratory conditions. The exterior mass concrete specimen beams for Mix 7 were prepared in the field by the USACE Pittsburgh District and shipped to the ERDC laboratory for testing.

Mixes conducted by ERDC were performed in a drum type mechanical mixer. First, half of the mixing water was mixed with coarse aggregate and air entraining admixture for $30 \mathrm{sec}$. The sand was then added and mixed for $15 \mathrm{sec}$. Finally, the cement and remaining mixing water was added and mixed in accordance to the standard ASTM C192 (ASTM 2016d) mixing sequence. The freshly mixed concrete was tested for the air content and slump were tested according to ASTM C143 (ASTM 2015c) and C231 (ASTM 2017d) respectively. The dosage of the air entraining agent was adjusted to obtain an air content of $6+/-1 / 2$ percent and a slump of 2-1/2 $+/-1 / 2$ in. Triplicate 3 -in. $\times 4$-in. $\times 16$-in. beam specimens were fabricated using steel molds. After casting, the specimen were stored in their molds covered with plastic sheets at $23^{\circ} \mathrm{C}, 100 \% \mathrm{RH}$ environmental conditions for $24 \mathrm{hr}$. The specimens were then demolded and cured in the same environmental conditions for 14 days before being subjected to the freezethaw cycle testing.

Test specimens were then placed in rectangular steel cans and surrounded by water. Freezing and thawing was accomplished by alternately circulating cold and warm antifreeze solutions around the steel cans. Each freezing and thawing cycle was carried out in approximately 2-hr intervals. The specimen chamber was cycled between 4 and $-18^{\circ} \mathrm{C}$ in $2 \mathrm{hr}$, so that 12 complete freezing-and-thawing cycles were executed in $24 \mathrm{hr}$. Specimens were removed from the freezing and thawing apparatus approximately every 3 days, and resonant frequency and mass determinations were made until the test specimen reached 300 cycles of freezing and thawing. 


\subsection{Calculations}

The relative dynamic modulus of elasticity, $P_{c}$, is defined by the following equation.

$$
P_{c}=\frac{\left(n_{1}\right)^{2}}{(n)^{2}} \times 100
$$

where

$$
\begin{aligned}
P_{c}= & \text { relative dynamic modulus of elasticity after c cycles of freezing } \\
& \text { and thawing, percent } \\
n= & \text { fundamental transverse frequency at o cycles of freezing and } \\
& \text { thawing } \\
n_{1}= & \text { fundamental transverse frequency after c cycles of freezing } \\
& \text { and thawing }
\end{aligned}
$$

The durability factor, DF, is defined by the following equation.

$$
\mathrm{DF}=\frac{\mathrm{P} \times \mathrm{N}}{\mathrm{M}}
$$

where

$$
\begin{aligned}
\mathrm{DF}= & \text { durability factor of the test specimen } \\
\mathrm{P}= & \text { relative dynamic modulus of elasticity at } \mathrm{N} \text { cycles, percent } \\
\mathrm{N}= & \text { number of cycles at which } \mathrm{P} \text { reaches the specified minimum } \\
& \text { value for discontinuing the test or the specified number of } \\
& \text { cycles at which the exposure is to be terminated, whichever is } \\
& \text { less } \\
\mathrm{M}= & \text { specified number of cycles at which the exposure is to be } \\
& \text { terminated. For the tests conducted on these specimen, the } \mathrm{M} \\
& \text { was continued only up to } 300 \text { cycles }
\end{aligned}
$$

\subsection{Results}

The average weight change, relative dynamic modulus, and durability factor at the final freeze-thaw cycle duration are summarized in Table 14 and illustrated in Figure 1. The durability factors ranged from a minimum of 61 to a maximum of 85 . Overall, the relative dynamic modulus of elasticity stayed above $60 \%$ for all test specimen throughout the 300 cycles of freezing and thawing. 
Table 14. Freezing and thawing final results.

\begin{tabular}{|c|c|c|c|c|}
\hline Mixture ID & \# Cycles & Mass Loss (\%) & $\begin{array}{c}\text { Relative Dynamic } \\
\text { Modulus (\%) }\end{array}$ & $\begin{array}{c}\text { Durability } \\
\text { Factor }\end{array}$ \\
\hline Hanson & 311 & 2.49 & 68 & 70 \\
\hline Shelly & 302 & 2.44 & 61 & 61 \\
\hline Georgetown & 300 & 1.39 & 69 & 69 \\
\hline Mix 7 & 300 & 1.06 & 85 & 85 \\
\hline
\end{tabular}


Figure 1. Durability factor and relative dynamic modulus with respect to number of freezing and thawing cycles.

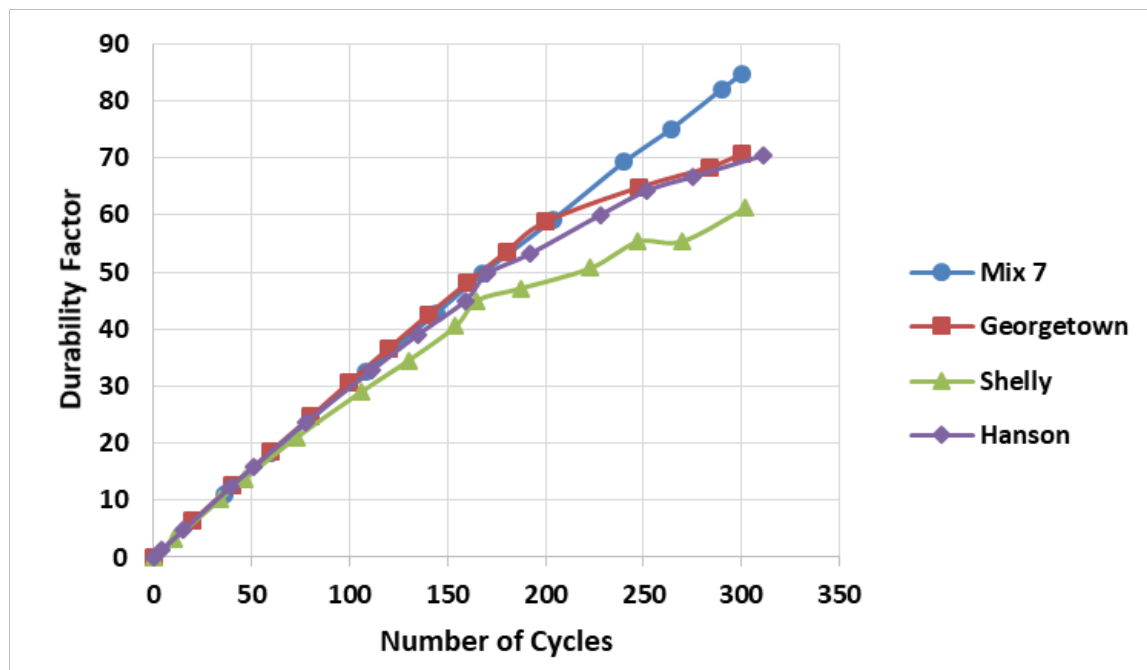

(a) Durability factor with respect to number of cycles.

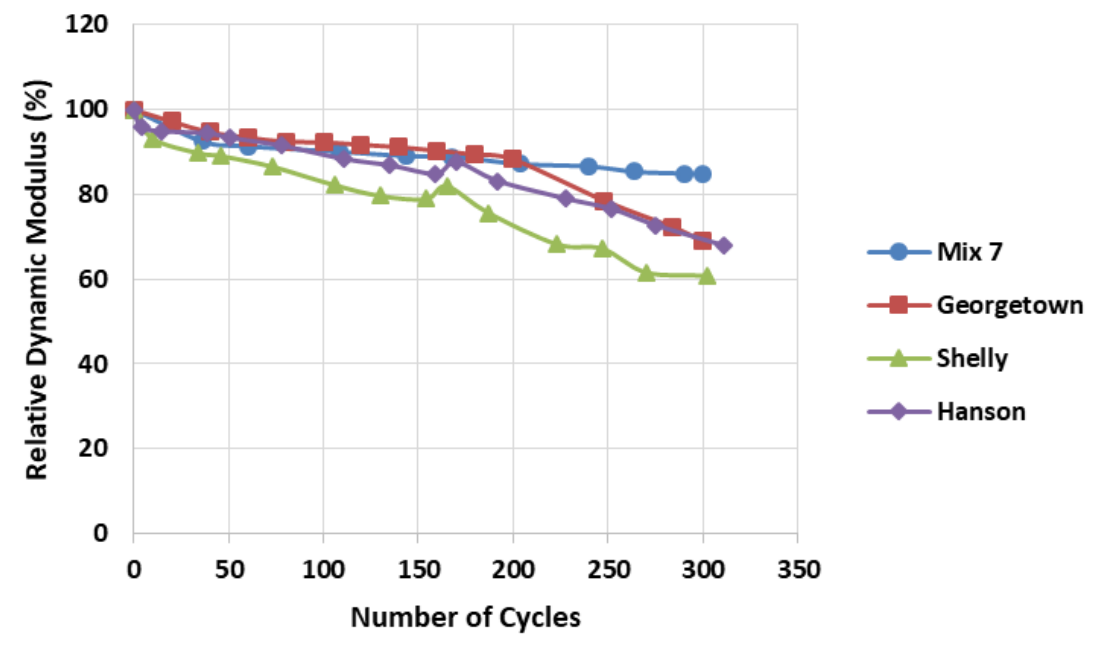

(b) Relative dynamic modulus of elasticity with respect to number of cycles. 


\section{Petrography Analysis}

Petrographic examination of three aggregates was performed according to the method described in ASTM C295 (ASTM 2017e) "Standard Practices for Petrographic Examination of Aggregates for Concrete." Along with the petrographic examination, X-ray diffraction was performed on the samples to identify the mineralogical composition of the received aggregate. The three samples were Georgetown, Hanson, and Shelly aggregates. They were ascribed CMB ID numbers of 150069, 150070, and 160004, respectively. Data associated with these aggregates are presented in Appendix C.

Each sieve size was examined with a petrographic microscope and photographed under a stereo-microscope. The ASTM requires 150 counts per sieve size; 300 particles were counted in this study to account for mineralogical variation. Samples were grouped into categories based on mineralogy and extent of weathering. The mineralogy of the sample was determined using X-ray diffraction (XRD) analysis. In preparation for $\mathrm{XRD}$ analysis, a portion of the sample was ground in a Pulverisette (Fritsch Co., Idar-Oberstein, Germany) and passed through a 45- $\mu \mathrm{m}$ (No. 325) sieve. Random orientation powder mounts of bulk samples were analyzed using XRD to determine the mineral constituents present in each sample. XRD patterns were gathered from an X-Pert Pro Multipurpose Powder Diffractometer system that used standard techniques for phase identification (Malvern Panalytical Inc.). The run conditions included Co$\mathrm{Ka}$ radiation and scanning from 2 to $70^{\circ}{ }_{2} \theta$ at a step size of $0.02{ }_{2}{ }_{2} \theta$ and an accelerating voltage of $45 \mathrm{kV}$ and $40 \mathrm{~mA}$ with collection of the diffraction patterns accomplished using the PC-based Windows version of X-Pert Pro Data Collector, and analysis of the patterns using the Jade2010 program (Materials Data Inc.) 


\subsection{Hanson aggregate}

The Hanson aggregate (Figure 2) was composed almost entirely of crushed siliceous limestone. The grains were noticeably crystalline with euhedral faces. Some grains exhibited an orangey stain. Inclusions of other minerals such as muscovite were present, yet rare. The aggregate did not appear to be heavily affected by weathering; the particles were crystalline and dense.

Figure 2. Photomicrographs of different sieve sizes for Hanson aggregate.

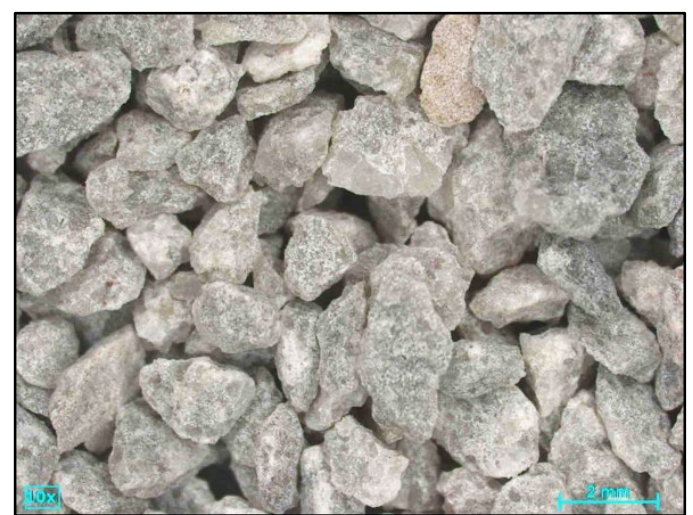

(a) 10x magnification of sieve size \#16.

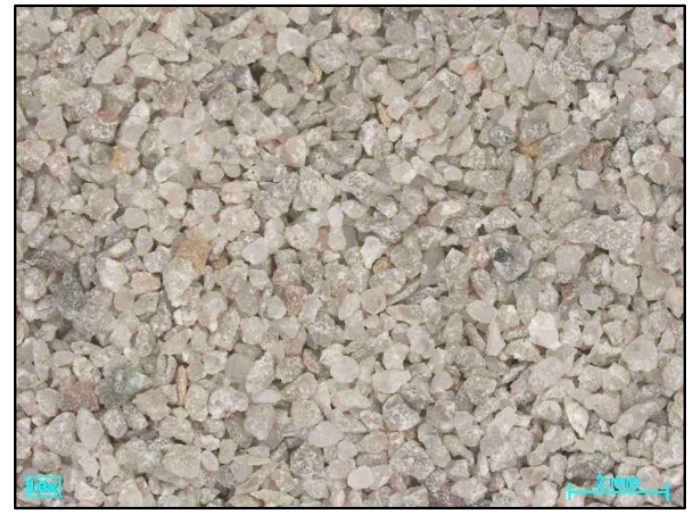

(c) 10x magnification of sieve size \#50.

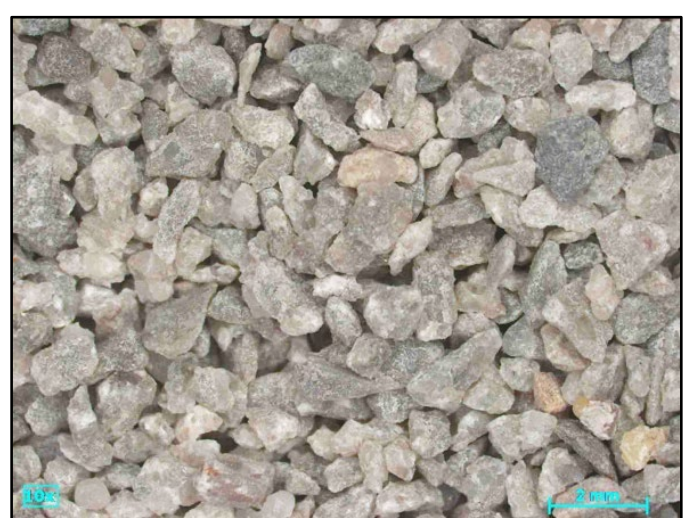

(b) 10x magnification of sieve size \#30.

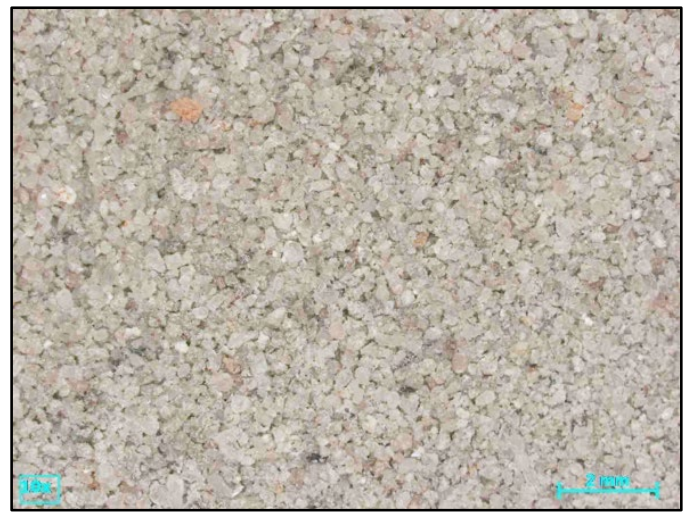

(d) 10x magnification of sieve size \#100.

The X-ray diffraction pattern obtained for this sample was used to identify and confirm the mineral constituents present in the aggregate. Calcite $\left(\mathrm{CaCO}_{3}\right)$ (55.7 percent), Quartz $\left(\mathrm{SiO}_{2}\right)(37.7 \%)$, micas Biotite $\left(\mathrm{K}(\mathrm{Mg}, \mathrm{Fe})_{3}\left(\mathrm{AlSi}_{3} \mathrm{O}_{10}\right)(\mathrm{F}, \mathrm{OH})_{2}\right)(5.1 \%)$, and Muscovite $\left.\left(\mathrm{KAl}_{2}\left(\mathrm{AlSi}_{3} \mathrm{O}_{10}\right)(\mathrm{F}, \mathrm{OH})_{2}\right)\right)(1.5 \%)$ were present. 


\subsection{Shelly aggregate}

The Shelly aggregate (Figure 3) was dominated by three separate lithologies, i.e., monomineralic quartz (A), sandstone/granite (B), and limestone (C). The quartz portion varied in shape ranging from angular to round. Its color was also variable exhibiting orangey and purple hues in the crystals indicating some impurity in the quartz. Lithology B ranged from quartz-rich sandstone to variations of granite evident by feldspars being present. The microcrystalline nature of these rocks made distinguishing their exact rock type difficult at the applied magnifications. It exhibited a sub-round to round shape. Lithology $\mathrm{C}$ was a limestone, often weathered as indicated by dissolution textures.

Figure 3. Photomicrographs of different sieve sizes for Shelly sand aggregate.

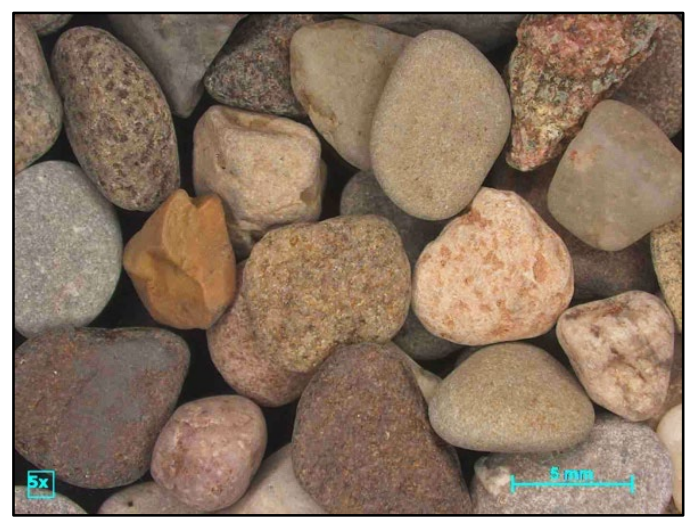

(a) 5.0x magnification of sieve size \#4.

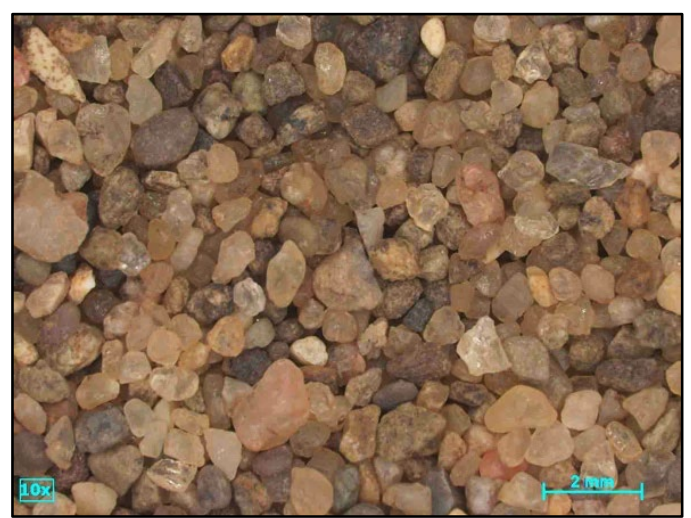

(c) 10x magnification of sieve size \#30.

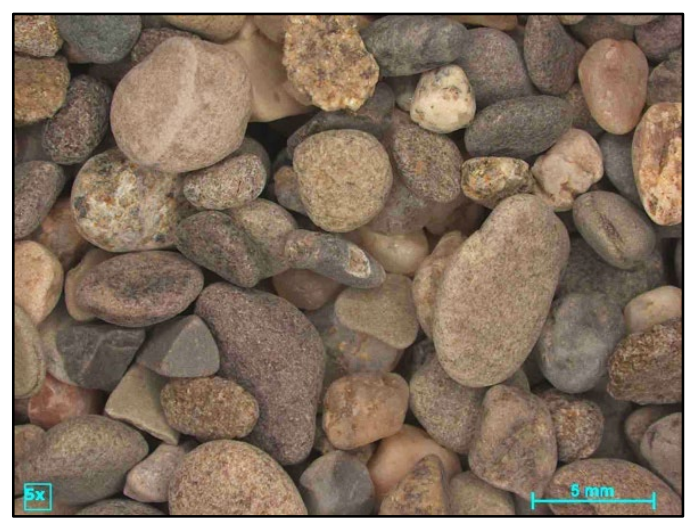

(b) 5.0x magnification of sieve size \#8.

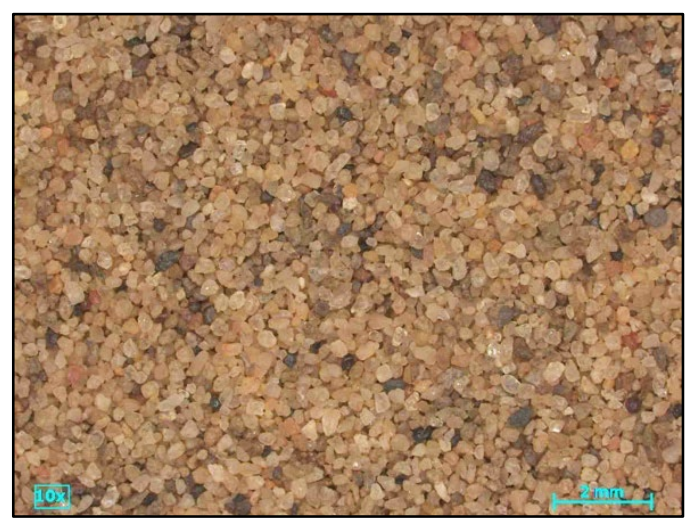

(d) 10x magnification of sieve size \#100.

The X-ray diffraction pattern obtained for this sample was used to identify and confirm the mineral constituents present in the aggregate, i.e., Quartz $\left(\mathrm{SiO}_{2}\right)(69.0 \%)$, Albite $\left(\mathrm{Na}\left(\mathrm{AlSi}_{3} \mathrm{O}_{8}\right)\right.$ (14.0\%), Graphite (C) (6.2\%), Calcite $\left(\mathrm{CaCO}_{3}\right)(4.4 \%)$, micas Biotite 
$\left(\mathrm{K}(\mathrm{Mg}, \mathrm{Fe})_{3}\left(\mathrm{AlSi}_{3} \mathrm{O}_{10}\right)(\mathrm{F}, \mathrm{OH})_{2}\right)(5.8 \%)$, and Muscovite $\left.\left(\mathrm{KAl}_{2}\left(\mathrm{AlSi}_{3} \mathrm{O}_{1 \mathrm{O}}\right)(\mathrm{F}, \mathrm{OH})_{2}\right)\right)(0.7 \%)$.

\subsection{Georgetown aggregate}

The Georgetown aggregate (Figure 4) consisted of three main lithologies, i.e., monomineralic quartz (A), sandstone/granite (B), and limestone (C). The quartz ranged from angular to round with variations in luster from opaque to translucent. An orangey coating was present on some grains. Inclusions and heterogeneities were present but rare. Lithology B consisted of microcrystalline quartz among other minerals, thus distinguishing between sandstone and granite was difficult. The crystals were often cemented together. Grains were round to sub-round and oxidized evident by the orangey coating. The limestone was heavily weathered, evident by the dissolution textures and porosity seen in the grains. Some of the grains had macroscopic fossils. 
Figure 4. Photomicrographs of different sieve sizes for Georgetown sand aggregate.

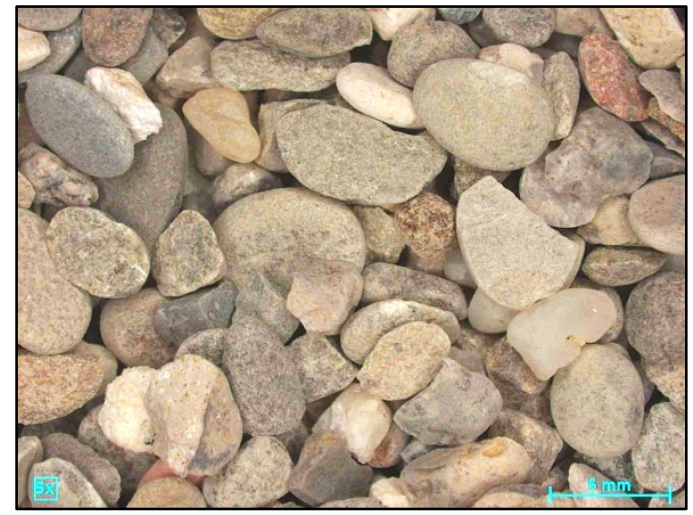

(a) 5.0x magnification of sieve size \#8.

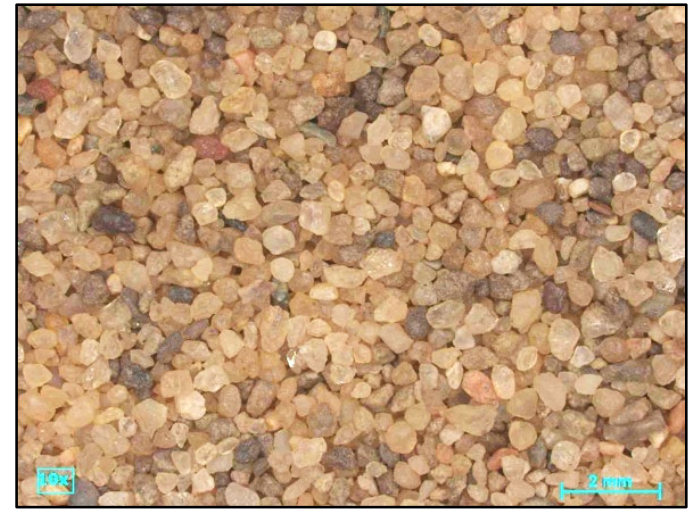

(c) 10x magnification of sieve size \#50.

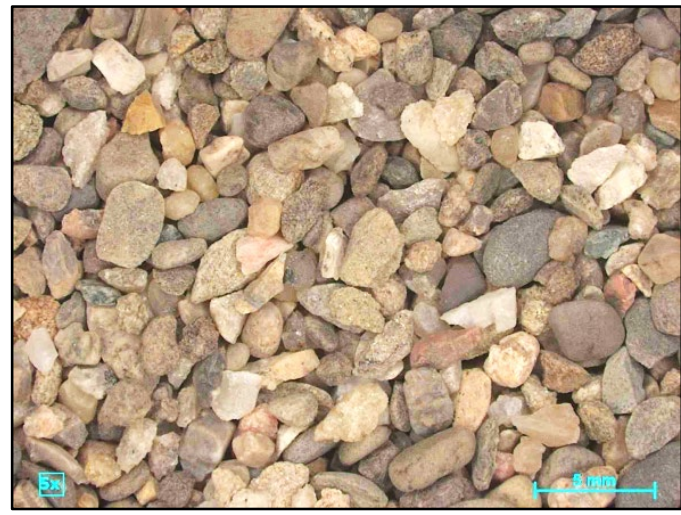

(b) 5.0x magnification of sieve size \#16.

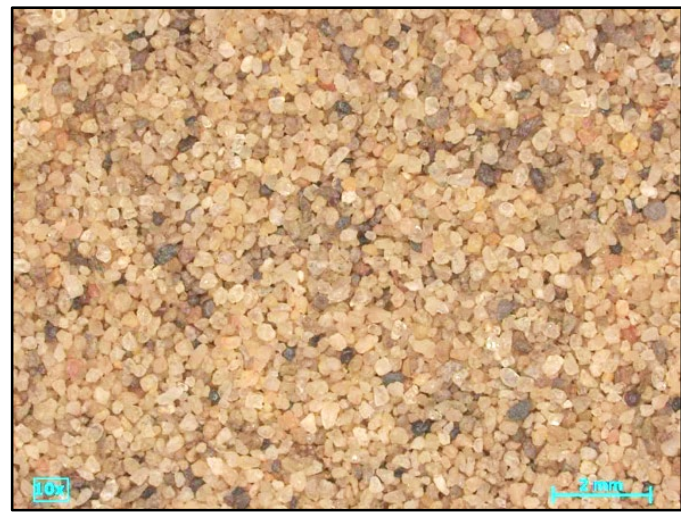

(d) 10x magnification of sieve size \#100.

The X-ray diffraction pattern obtained for this sample was used to identify and confirm the mineral constituents present in the aggregate, i.e., Quartz $\left(\mathrm{SiO}_{2}\right)(70.1 \%)$, Albite $\left(\mathrm{Na}\left(\mathrm{AlSi}_{3} \mathrm{O}_{8}\right)(16.0 \%)\right.$, Calcite $\left(\mathrm{CaCO}_{3}\right)(5.6 \%)$, micas Biotite $\left(\mathrm{K}(\mathrm{Mg}, \mathrm{Fe})_{3}\left(\mathrm{AlSi}_{3} \mathrm{O}_{10}\right)(\mathrm{F}, \mathrm{OH})_{2}\right)(5.2 \%)$, and Muscovite $\left.\left(\mathrm{KAl}_{2}\left(\mathrm{AlSi}_{3} \mathrm{O}_{10}\right)(\mathrm{F}, \mathrm{OH})_{2}\right)\right)(3.2 \%)$. 


\section{Cementitious Analysis}

Potential cementitious project materials were provided to the ERDC for compliance testing in accordance to the Charleroi L\&D specifications. This section provides result summaries of each cementitious material tested. Additional test reports can be found in Appendix D.

\subsection{Portland cement}

A type II (MH) cement produced by Armstrong in Cabot, PA, was tested in accordance to ASTM C150 (ASTM 2018c). The chemical analysis included a calculation of the equivalent alkalies content to determine low-alkali (LA) cement criteria. The heat of hydration (HH) and false set (FS) optional physical requirements as specified in table 4 of ASTM C150 were also tested. A summary of the chemical and physical properties are given in Table 15. The Armstrong cement met all ASTM C150 specification requirements for a Type II (MH) cement and was in compliance with the LA, FS, and HH criteria required by the Charleroi L\&D specifications. 
Table 15. Armstrong cement tested in accordance to ASTM C150.

\begin{tabular}{|c|c|c|}
\hline Chemical Analysis & Test Results & Spec Limits \\
\hline $\mathrm{SiO}_{2}, \%$ & 20.48 & - \\
\hline $\mathrm{Al}_{2} \mathrm{O}_{3}, \%$ & 4.59 & $6.0 \% \max$ \\
\hline $\mathrm{Fe}_{2} \mathrm{O}_{3}, \%$ & 6.3 & A $6.0 \% \max$ \\
\hline $\mathrm{CaO}, \%$ & 62.7 & - \\
\hline MgO, \% & 1.24 & $6.0 \% \max$ \\
\hline $\mathrm{SO}_{3}, \%$ & 2 & $3.0 \% \max$ \\
\hline $\mathrm{Na}_{2} \mathrm{O}, \%$ & 0.13 & - \\
\hline $\mathrm{K}_{2} \mathrm{O}, \%$ & 0.66 & - \\
\hline Equivalent Alkalis-total as $\mathrm{Na}_{2} \mathrm{O}, \%$ & 0.56 & в $0.60 \% \max$ \\
\hline Loss on ignition, \% & 0.45 & $3.0 \% \max$ \\
\hline Tricalcium silicate $\left(\mathrm{C}_{3} \mathrm{~S}\right)$ & 54 & - \\
\hline Dicalcium silicate $\left(\mathrm{C}_{2} \mathrm{~S}\right)$ & 18 & - \\
\hline Tricalcium aluminate $\left(\mathrm{C}_{3} \mathrm{~A}\right)$ & 2 & 8 \\
\hline Tetracalcium aluminoferrite $\left(\mathrm{C}_{3} \mathrm{AF}\right)$ & 19 & - \\
\hline Sum of $\mathrm{C}_{3} \mathrm{~S}+4.75 \mathrm{C}_{3} \mathrm{~A}$ & 63.5 & 100 \\
\hline Physical Analysis & Test Results & Spec Limits \\
\hline Air content $(\%)$ & 7.9 & $12 \% \max$ \\
\hline Surface area $\left(\mathrm{m}^{2} / \mathrm{kg}\right)$ & 329 & $260 \min$ \\
\hline Autoclave expansion (\%) & 0.02 & $0.80 \% \max$ \\
\hline Initial set by Vicat (minutes) & 155 & $45 \min$ \\
\hline Final set by Vicat (minutes) & 290 & $375 \max$ \\
\hline Compressive strength, 3 day (psi) & 1,525 & c 1,020 psi min \\
\hline Compressive strength, 7 day (psi) & 1,920 & c 1,740 psi min \\
\hline Compressive strength, 28 day (psi) & 4,175 & D 3,190 psi min \\
\hline Heat of Hydration, 3 days (J/g) & 185 & D $255 \mathrm{~J} / \mathrm{G} \max$ \\
\hline Heat of Hydration, 7 days $(\mathrm{J} / \mathrm{g})$ & 240 & - \\
\hline Heat of Hydration, 28 days $(\mathrm{J} / \mathrm{g})$ & 330 & - \\
\hline False set (\%) & 80 & $50 \% \min$ \\
\hline
\end{tabular}

A Does not apply when heat of hydration limit in Table 4 is specified

B Limit in Table 2 for low-alkali cement

C Required only when optional heat of hydration in Table 4 is specified

D As specified in Table 4 optional physical requirements 


\subsection{Fly ash}

Class F fly ashes from four sources were tested in accordance to ASTM C618 (ASTM 2017h) "Standard Specification for Coal Fly Ash and Raw or Calcined Natural Pozzolan for Use in Concrete.” Two fly ashes produced by Headwaters Resources (Sammis plant located in Stratton, OH, and Fort Martin plant located in Maidsville, WV) were initially submitted for evaluation. However, both plants closed almost simultaneously in the fall of 2017. Two other sources of fly ash produced by Separation Technologies (Longview Plant in Maidsville, WV, and Brandon Shores Plant in Curtis Bay, MD) were then submitted for compliance testing. Chemical and physical analysis results of the four fly ashes are detailed in Table 16.

Table 16. Fly ash results tested in accordance to ASTM C618.

\begin{tabular}{|c|c|c|c|c|c|}
\hline \multicolumn{6}{|c|}{ Chemical Analysis } \\
\hline Component & $\begin{array}{l}\text { Sammis } \\
\text { Fly Ash }\end{array}$ & \begin{tabular}{|l} 
Ft. Martin \\
Fly Ash
\end{tabular} & $\begin{array}{l}\text { Longview } \\
\text { Fly Ash }\end{array}$ & $\begin{array}{l}\text { Brandon Shores } \\
\text { Fly Ash }\end{array}$ & Spec Limits \\
\hline $\mathrm{SiO}_{2}, \%$ & 44.2 & 52.6 & 50.81 & 45.95 & - \\
\hline $\mathrm{Al}_{2} \mathrm{O}_{3}, \%$ & 20.2 & 22.5 & 21.75 & 22.42 & - \\
\hline $\mathrm{Fe}_{2} \mathrm{O}_{3}, \%$ & 24.2 & 13.5 & 15.64 & 21.49 & - \\
\hline Sum, \% & 88.6 & 88.6 & 88.2 & 89.86 & $70.0 \% \min$ \\
\hline $\mathrm{Na}_{2} \mathrm{O}, \%$ & 2.87 & 2.49 & 0.62 & 0.45 & - \\
\hline $\mathrm{K}_{2} \mathrm{O}, \%$ & 2.05 & 2 & 2.36 & 1.85 & - \\
\hline $\mathrm{CaO}, \%$ & 0 & 1.1 & 3.37 & 2.64 & - \\
\hline $\mathrm{MgO}, \%$ & 0.9 & 0.9 & 1.07 & 0.79 & - \\
\hline $\mathrm{SO}_{3}, \%$ & 0.6 & 0.3 & 0.92 & 0.82 & $5.0 \% \max$ \\
\hline Loss on Ignition, \% & 2.99 & 3.1 & 1.9 & 2 & $6.0 \% \max$ \\
\hline Moisture Content, \% & 0.11 & 0.13 & 0.13 & 0.3 & $3.0 \% \max$ \\
\hline \multicolumn{6}{|c|}{ Physical Analysis } \\
\hline Property & $\begin{array}{l}\text { Sammis } \\
\text { Fly Ash }\end{array}$ & $\begin{array}{c}\text { Ft. Martin } \\
\text { Fly Ash }\end{array}$ & $\begin{array}{c}\text { Longview } \\
\text { Fly Ash }\end{array}$ & $\begin{array}{c}\text { Brandon Shores } \\
\text { Fly Ash } \\
\end{array}$ & Spec Limits \\
\hline Strength Activity \% 7 day & 71 & 64 & 68 & 77 & A $75 \% \min$ \\
\hline Strength Activity \% 28 day & 72 & 65 & 78 & 76 & A $75 \% \min$ \\
\hline Water Requirement, \% & 100 & 100 & 99 & 98 & $105 \% \max$ \\
\hline Specific Gravity & 2.6 & 2.52 & 2.34 & 2.41 & $5 \% \max$ \\
\hline Soundness, \%, & 0.001 & 0.001 & -0.03 & -0.06 & $0.8 \% \max$ \\
\hline Fineness, \% & 25.92 & 23.85 & 38.6 & 19.12 & $34 \% \max$ \\
\hline $\begin{array}{l}\text { Increase of drying } \\
\text { shrinkage at } 28 \text { days }\end{array}$ & 0.05 & 0.001 & 0.01 & 0.01 & - \\
\hline $\begin{array}{l}\text { Uniformity Requirement, } \\
\text { amount of Vinsol }\end{array}$ & 0.2 & 0.2 & 0.16 & 0.15 & - \\
\hline
\end{tabular}

A Meeting the 7 day or 28 day strength activity index will indicate specification compliance. Armstrong Type II (MH) project cement was used for reference cement for strength activity index tests. 
Only the Brandon Shores fly ash met all physical requirements of ASTM C618. The Sammis fly ash fell below the $75 \%$ minimum strength activity requirement at 7 and 28 days with results of $71 \%$ and $72 \%$, respectively. Similarly the Fort Martin fly produced a strength activity index of $64 \%$ at 7 days and $65 \%$ at 28 days. The Longview fly ash failed at 7 days with $68 \%$ strength activity index and also exceeded the $34 \%$ fineness allowed on a \#325 sieve with $38.6 \%$ retained.

Table 2 of ASTM C618 notes the strength activity index with portland cement is not to be considered a measure of the compressive strength of concrete containing the fly ash. The mass of fly ash specified for the test to determine the strength activity index with portand cement is not considered to be the proportion recommended for the concrete to be used in the work. The optimum amount of fly ash for any specific project is determined by the required properties of the concrete and other constituents of the concrete and is to be established by testing. Strength activity index with portland cement is a measure of reactivity with a given cement and is subject to variation depending on the source of both the fly ash and the cement. Meeting the 7-day or 28-day strength activity index will indicate specification compliance. It is at the District's discursion to accept or reject each fly ash source. 


\subsection{Slag cement}

Slag cement grade 100 produced by the Argos-Essroc-Lehigh source located in Middlebranch, OH, was tested in accordance to ASTM C989 (ASTM 2018d) "Standard Specification for Slag Cement for Use in Concrete and Mortars." A summary of the chemical and physical properties given in Table 17 indicate this slag satisfied the ASTM C989 specification requirements.

Table 17. Argos-Essroc slag, grade 100 results tested in accordance to ASTM C989.

\begin{tabular}{|c|c|c|}
\hline Chemical Analysis & Test Results & Spec Limits \\
\hline Sulfide Sulfur, S \% & 2.02 & $2.5 \% \max$ \\
\hline Sulfate Sulfur, (as $\left.\mathrm{SO}_{3}\right) \%$ & 0.04 & $4 \% \max$ \\
\hline Aluminum Oxide, (as $\left.\mathrm{Al}_{2} \mathrm{O}_{3}\right) \%$ & 10.15 & - \\
\hline Chloride Content of Slag & 0.05 & - \\
\hline $\mathrm{Na}_{2} \mathrm{O}, \%$ & 0.27 & - \\
\hline $\mathrm{K}_{2} \mathrm{O}, \%$ & 0.47 & - \\
\hline Equivalent Alkalis-total as $\mathrm{Na}_{2} \mathrm{O}, \%$ & 0.57 & \\
\hline Physical Analysis & Test Results & Spec Limits \\
\hline Compressive strength, (psi) 7 day, ${ }^{1}$ Reference & 1,880 & - \\
\hline Compressive strength, (psi) 28 day, ${ }^{1}$ Reference & 3,956 & - \\
\hline Compressive strength, (psi) 7 day, Slag/Cement & 1,583 & - \\
\hline Compressive strength, (psi) 28 day, Slag/Cement & 3,802 & - \\
\hline Strength Activity Index,( \%) 7 day & 88 & $70 \% \min$ \\
\hline Strength Activity Index, (\%) 28 day & 96 & $90 \% \min$ \\
\hline Surface area, $\mathrm{m}^{2} / \mathrm{kg}$ & 626 & $260 \mathrm{~min}$ \\
\hline Specific Gravity, ASTM C188 & 2.81 & - \\
\hline Fineness, \% Retained on \#325 & 2.8 & $20 \% \max$ \\
\hline Air content, \% & 4.2 & $12 \% \max$ \\
\hline
\end{tabular}

Notes:

${ }^{1}$ Armstrong Type II project cement was used for reference cement for strength activity index tests. 


\subsection{Silica fume}

Microsilica grade $970 \mathrm{D}$ produced by Norkem Chemicals Inc. and provided by Elkem Materials was tested in accordance to ASTM C1240 (ASTM 2015e), "Standard Specification for Silica Fume Used in Cementitious Mixtures." A summary of the chemical and physical properties given in Table 18 indicate this silica fume satisfied the ASTM C1240 specification requirements.

Table 18. Elkem grade 970D silica fume results tested in accordance to ASTM C1240.

\begin{tabular}{|l|l|l|}
\hline \multicolumn{1}{|c|}{ Chemical Analysis } & Test Results & Spec. Limits \\
\hline SiO2, \% & 95.16 & $85 \%$, min \\
\hline Al203, \% & 0.24 & - \\
\hline Fe203, \% & 0.52 & - \\
\hline Sum, \% & 95.92 & - \\
\hline Na20, \% & 0.3 & - \\
\hline K20, \% & 0.49 & - \\
\hline Mg0, \% & 0.25 & - \\
\hline S03, \% & 0.01 & - \\
\hline Loss on ignition, \% & 2.61 & $6 \%$, max \\
\hline Moisture \% & 0.61 & $3 \%$, max \\
\hline \multicolumn{1}{|c|}{ Physical Analysis } & Test Results & Spec. Limits \\
\hline Control Mixture ${ }^{1}$ Compressive strength, 7 day (psi) & 1,990 & - \\
\hline Test Mixture ${ }^{2}$ Compressive strength, 7 day (psi) & 3,280 & - \\
\hline Strength Activity Index,( \%) 7 day & 165 & $105 \%$, min \\
\hline Water Requirement & 3 & $100-115 \%$ \\
\hline Specific Gravity & 2.32 & - \\
\hline Uniformity Requirement, amount of Vinsol & $0.04 \mathrm{~g}$ & - \\
\hline Effectiveness in Controlling ASR at 14 days & $95 \%$ & $80 \%$, min \\
\hline
\end{tabular}

1, 2 Armstrong Type II project cement was used for reference cement for strength activity index tests. ${ }^{3}$ Following the standard ASTM C1240 method, $2 \mathrm{~mL}$ of HRWRA required with test mixture to produce flow limits using $242 \mathrm{~mL}$ of water. 


\subsection{Limestone powder}

The Graymont limestone powder produced by the facility in Bellefonte, PA, was tested in accordance to ASTM C1271 (ASTM 2012) "Standard Test Method for X-ray Spectrometric Analysis of Lime and Limestone," ASTM D546 (ASTM 2017g) "Standard Test Method for Sieve Analysis of Mineral Filler for Asphalt Paving Mixtures," and ASTM D242 "Standard Specification for Mineral Filler for Bituminous Paving Mixtures" (ASTM 2014b). The chemical and sieve analysis results are detailed in Table 19. The material is composed primarily of calcium carbonate $\left(\mathrm{CaCo}_{3}\right)$ and considered non-plastic Silty Sand (SM), Gray when tested by ASTM D4318 procedures. The mineral filler met the grading limits established in ASTM D242. 
Table 19. Limestone powder analysis summary results.

\begin{tabular}{|c|c|c|c|c|c|c|c|c|c|}
\hline \multicolumn{10}{|c|}{ ASTM C1271 X-ray Spectrometric Analysis of Limestone } \\
\hline \multicolumn{5}{|c|}{ Chemical Analysis } & \multicolumn{5}{|c|}{ Test Results } \\
\hline \multicolumn{5}{|l|}{$\mathrm{SiO}_{2}, \%$} & \multicolumn{5}{|l|}{0.95} \\
\hline \multicolumn{5}{|l|}{$\mathrm{Al}_{2} \mathrm{O}_{3}, \%$} & \multicolumn{5}{|l|}{0.38} \\
\hline \multicolumn{5}{|l|}{$\mathrm{Fe}_{2} \mathrm{O}_{3}, \%$} & \multicolumn{5}{|l|}{0.15} \\
\hline \multicolumn{5}{|l|}{$\mathrm{CaO}, \%$} & \multicolumn{5}{|l|}{54.18} \\
\hline \multicolumn{5}{|l|}{$\mathrm{Na20} \%$} & \multicolumn{5}{|l|}{0.04} \\
\hline \multicolumn{5}{|l|}{$\mathrm{K} 2 \mathrm{O}, \%$} & \multicolumn{5}{|l|}{0.09} \\
\hline \multicolumn{5}{|l|}{ MgO, \% } & \multicolumn{5}{|l|}{0.71} \\
\hline \multicolumn{5}{|c|}{ Loss on ignition $\left(950^{\circ} \mathrm{C}\right), \%$} & \multicolumn{5}{|l|}{43.29} \\
\hline \multicolumn{5}{|c|}{$\mathrm{Ca}$ as $\mathrm{CaCO}_{3}, \%$} & \multicolumn{5}{|l|}{96.69} \\
\hline \multicolumn{5}{|c|}{$\mathrm{Mg}$ as $\mathrm{MgCO}_{3}, \%$} & \multicolumn{5}{|l|}{1.49} \\
\hline \multicolumn{5}{|c|}{ Calculated Carbonates as $\mathrm{CO}_{2}$} & \multicolumn{5}{|l|}{43.29} \\
\hline \multicolumn{5}{|c|}{ L.O.I. / $\mathrm{CO}_{2}$ Balance } & \multicolumn{5}{|l|}{1} \\
\hline \multicolumn{5}{|c|}{$\mathrm{Mg}$ as $\mathrm{CaMg}\left(\mathrm{CO}_{3}\right)_{2}, \%$} & 3.26 & & & & \\
\hline Residual C & as $\mathrm{CaCO}_{3}$, & & & & 94.92 & & & & \\
\hline & ASTM & 546 Sie & e Analys & is of Mine & al Filler fo & Bitumin & Dus Paving $\Lambda$ & ixtures & \\
\hline & Run 1 & & Cumulati & e Percent & Run 2 & & Cumulative & Percent & \\
\hline Sieve Size & $\begin{array}{l}\text { Mass } \\
\text { Retained } \\
\text { (g) }\end{array}$ & $\begin{array}{l}\% \\
\text { Retaine } \\
d\end{array}$ & $\begin{array}{l}\text { \% } \\
\text { Retaine } \\
d\end{array}$ & $\begin{array}{l}\% \\
\text { Passing }\end{array}$ & $\begin{array}{l}\text { Mass } \\
\text { Retained } \\
\text { (g) }\end{array}$ & $\begin{array}{l}\% \\
\text { Retained }\end{array}$ & $\begin{array}{l}\% \\
\text { Retained }\end{array}$ & $\begin{array}{l}\% \\
\text { Passing }\end{array}$ & $\begin{array}{l}\text { Avg. \% } \\
\text { Passing }\end{array}$ \\
\hline No. 16 & 0.00 & 0.00 & 0.00 & 100 & 0.00 & 0.00 & 0.00 & 100 & 100 \\
\hline No. 30 & 0.52 & 0.51 & 0.51 & 99.49 & 0.60 & 0.53 & 0.53 & 99.47 & 99.48 \\
\hline No. 50 & 0.50 & 0.49 & 1.00 & 99.00 & 0.58 & 0.51 & 1.04 & 98.96 & 98.98 \\
\hline No. 100 & 1.93 & 1.89 & 2.89 & 97.11 & 2.08 & 1.83 & 2.87 & 97.13 & 97.12 \\
\hline No. 200 & 22.00 & 21.56 & 24.45 & 75.55 & 24.16 & 21.25 & 24.12 & 75.88 & 75.72 \\
\hline $\begin{array}{l}\text { Minus } \\
\text { No.200 }\end{array}$ & 77.09 & 75.55 & 100 & & 86.28 & 75.88 & 100 & & \\
\hline $\begin{array}{l}\text { Original } \\
\text { Sample }\end{array}$ & 102 & 100 & & & 113.70 & 100 & & & \\
\hline$\frac{\text { Remarks: }}{(2017 \mathrm{~g}) .}$ & imestone $p$ & wder mat & rial is cons & dered non & astic silty s & and (SM), $\varepsilon$ & ay when tes & d by ASTM & 4318 \\
\hline & & ASTM D & 242 Min & ral Filler & or Bitumi & lous Pavi & g Mixtures & & \\
\hline Sieve No. & & & Aver & age Test Re & & & ASTM D242 & raded Limit & \\
\hline No. 16 & & & 100 & & & & 100 & & \\
\hline No. 30 & & & 99.4 & & & & 97 to 100 & & \\
\hline No. 50 & & & 98.5 & & & & 95 to 100 & & \\
\hline No. 200 & & & 75.7 & & & & 70 to 100 & & \\
\hline
\end{tabular}




\section{Early Stiffening of Mortar}

The early development of stiffness in the working characteristics of the hydraulic-cement mortar designs of mix 1, 5, 7, and 10 were tested in accordance to ASTM C359 (ASTM 2013). The four fly ash sources were evaluated independently with each mix design for a total of 16 tests. Mortars were prepared using specified quantities of cementitious materials scaled from the mixture designs with adequate mixing water to produce an initial penetration of $46 \pm 3 \mathrm{~mm}$ using a modified Vicat apparatus. Measurements of penetration were made at stipulated intervals after the beginning of the mixing procedure. Upon completion of the first series of penetration measurements, the mortar was remixed followed by a final penetration measurement. A tabulation of the penetration measurements and the amount of mixing water used in the 16 tests is detailed in Table 20. The early stiffening rate of the 16 mortars ranged from a minimum of $5.3 \mathrm{~mm} / \mathrm{min}$ to a maximum of $7.2 \mathrm{~mm} / \mathrm{min}$ and the overall recovery ranged from a minimum of $96 \%$ to a maximum of $100 \%$. This indicates a low potential of early stiffening of the hydraulic mortars. 
Table 20. Early stiffening of Mix 1, 5, 7, and 10 tested in accordance to ASTM C359.

\begin{tabular}{|c|c|c|c|c|c|c|c|c|c|c|}
\hline $\begin{array}{c}\text { Mix } \\
\#\end{array}$ & Fly Ash Source & $\begin{array}{l}\text { Mixing } \\
\text { Water } \\
(\mathrm{mL})\end{array}$ & $\begin{array}{l}\text { Initial } \\
\text { pen. } \\
(\mathrm{mm})\end{array}$ & $\begin{array}{l}\text { 5-min } \\
\text { pen. } \\
(\mathrm{mm})\end{array}$ & $\begin{array}{l}\text { 8-min } \\
\text { pen. } \\
(\mathrm{mm})\end{array}$ & $\begin{array}{l}\text { 11-min } \\
\text { pen. } \\
(\mathrm{mm})\end{array}$ & $\begin{array}{l}\text { Remix } \\
\text { pen. } \\
(\mathrm{mm})\end{array}$ & $\begin{array}{c}\text { Early Stiffening } \\
\text { Amount } \\
(\mathrm{mm})\end{array}$ & $\begin{array}{c}\text { Early Stiffening } \\
\text { Rate } \\
(\mathrm{mm} / \mathrm{min})\end{array}$ & $\begin{array}{c}\text { Early Stiffening } \\
\text { Recovery } \\
\text { (\%) }\end{array}$ \\
\hline \multirow[b]{4}{*}{$\stackrel{r}{r}$} & Sammis & 185 & 49 & 10 & 5 & 3 & 49 & 46 & 7.3 & 100 \\
\hline & Ft. Martin & 185 & 45 & 7 & 4 & 2 & 45 & 43 & 6.9 & 100 \\
\hline & Longview & 183 & 46 & 11 & 6 & 3 & 44 & 43 & 6.7 & 96 \\
\hline & $\begin{array}{l}\text { Brandon } \\
\text { Shores }\end{array}$ & 180 & 46 & 10 & 4 & 2 & 45 & 44 & 6.9 & 98 \\
\hline \multirow[b]{4}{*}{ 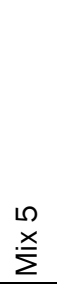 } & Sammis & 175 & 46 & 18 & 5 & 3 & 45 & 43 & 6.3 & 98 \\
\hline & Ft. Martin & 180 & 45 & 26 & 10 & 5 & 45 & 40 & 5.5 & 100 \\
\hline & Longview & 175 & 48 & 20 & 6 & 4 & 46 & 44 & 6.4 & 96 \\
\hline & $\begin{array}{l}\text { Brandon } \\
\text { Shores }\end{array}$ & 173 & 45 & 18 & 4 & 3 & 43 & 42 & 6.2 & 96 \\
\hline \multirow[b]{4}{*}{$\stackrel{r}{i x}$} & Sammis & 180 & 47 & 20 & 6 & 4 & 46 & 43 & 6.3 & 98 \\
\hline & Ft. Martin & 180 & 46 & 25 & 9 & 4 & 46 & 42 & 5.8 & 100 \\
\hline & Longview & 175 & 45 & 18 & 6 & 4 & 44 & 41 & 6.1 & 98 \\
\hline & $\begin{array}{l}\text { Brandon } \\
\text { Shores }\end{array}$ & 175 & 44 & 17 & 6 & 3 & 43 & 41 & 6.1 & 98 \\
\hline \multirow[b]{4}{*}{$\begin{array}{l}\stackrel{0}{-} \\
\stackrel{x}{\Sigma}\end{array}$} & Sammis & 170 & 46 & 31 & 11 & 6 & 46 & 40 & 5.3 & 100 \\
\hline & Ft. Martin & 170 & 46 & 30 & 12 & 6 & 46 & 40 & 5.3 & 100 \\
\hline & Longview & 166 & 45 & 28 & 9 & 5 & 43 & 40 & 5.4 & 96 \\
\hline & $\begin{array}{l}\text { Brandon } \\
\text { Shores }\end{array}$ & 165 & 45 & 28 & 10 & 5 & 44 & 40 & 5.4 & 98 \\
\hline
\end{tabular}




\section{Water Quality Test Results}

Municipal water from the Charleroi water authority (sample ID 150088) and well water from the left bank batch plant area (sample ID 150089) were tested for water quality in accordance to CRD-C 400 (U.S. Army Corps of Engineers 1963). Both filtered and unfiltered water quality samples were tested for iron by EPA Method 300.0, sulfate and chloride anions by EPA $6000 / 7000$ series method, and hydrogen-ion concentration by EPA method 150.1. Detailed test results are provided Appendix F. Both filtered samples and the unfiltered municipal water met the criteria requirements for analytes tested. The unfiltered well water failed the limiting criteria for iron and chloride ions in the water. The well had not been circulating at the time the water sample was provided, and settled solids were observed as illustrated in Figure 5. It is notable to mention the unfiltered well water was never used as batch water for the project.

Figure 5. Visible settled solids in well water sample from left bank batch plant area.

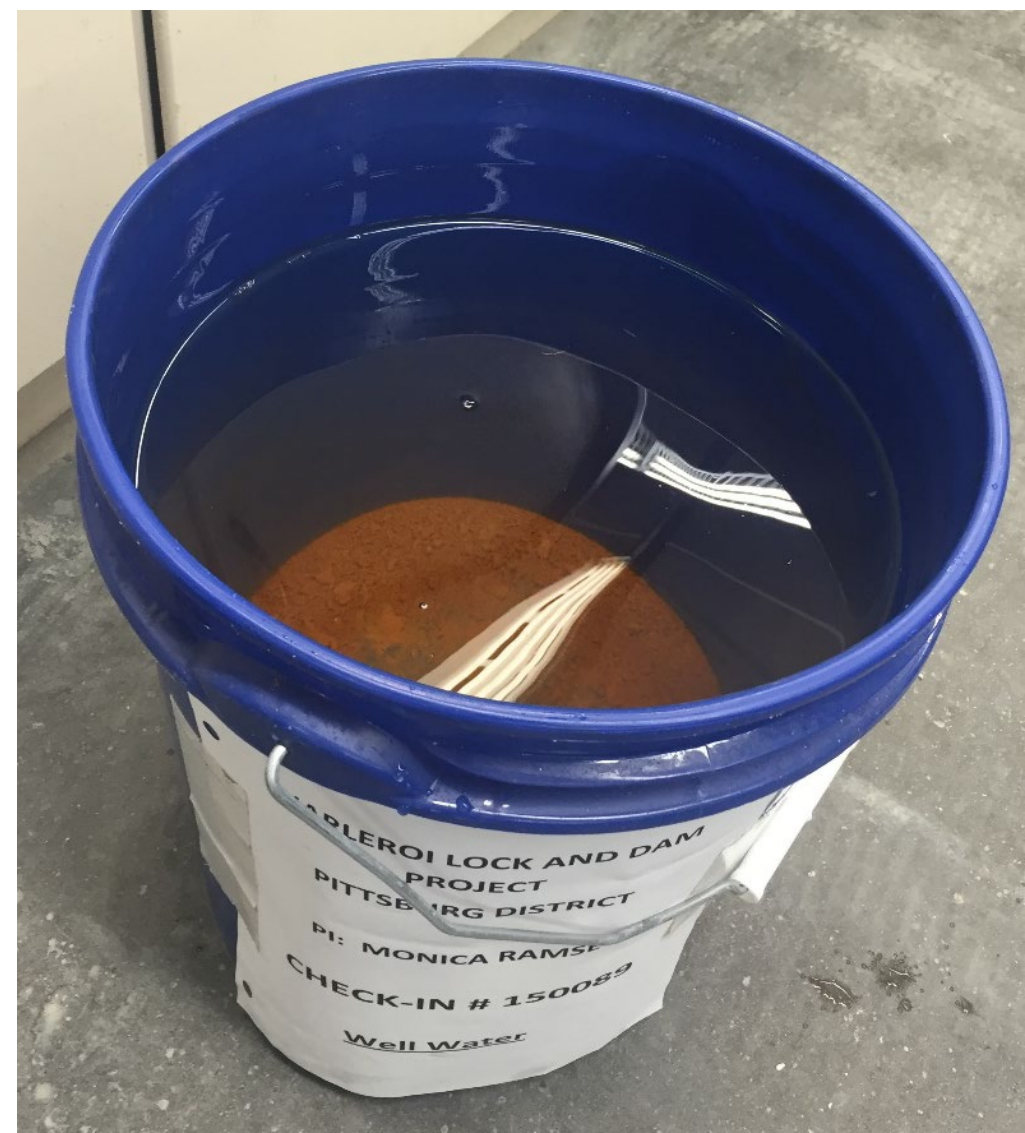




\section{Chemical Admixture Testing}

Test results on five chemical admixtures produced by the Euclid Chemical Company are presented in this section. The manufacturer's reports are provided in Appendix E. Project source materials were used in the proportioning of the concrete mixtures as prescribed in ASTM C494 (ASTM 2017f).

\subsection{Air entraining admixture (AEA)}

Eucon AEA-92 formulated by the Euclid Chemical Company was the air entraining agent proposed for the Charleroi L\&D concrete mixtures. The admixture is a liquid solution of synthetic organic chemicals compatible with concrete mixes containing calcium chloride, water reducing admixtures, retarding admixtures, or high-range water reducers.

Abbreviated testing was performed in accordance to ASTM C494 (ASTM 2017f) and ASTM C260 (ASTM 2016e). Results of the resistance to freezing and thawing performance requirement using this admixture was presented earlier. The same concrete mixture proportions used for the freezing and thawing testing of the Hanson coarse aggregate and other project materials was the control concrete for other physical tests. Compressive strength specimens were fabricated in accordance to ASTM C192 (ASTM 2016d) and tested in accordance to ASTM C39 (ASTM 2018a) procedures using triplicate $4 \times 8 \mathrm{in}$. specimens at each test age. Strength results presented in Table 21 indicate the Eucon AEA-92 meets the requirement for a level of performance comparable to the control concrete.

Table 21. Compressive strength results comparing control and AEA-92 concrete.

\begin{tabular}{|c|c|c|}
\hline Physical Analysis & Test Results & $\begin{array}{c}\text { ASTM C260 } \\
\text { Spec Limits }\end{array}$ \\
\hline Compressive strength, (psi) 3 day, Control & 3,750 & \\
\hline Compressive strength, (psi) 7 day, Control & 4,300 & - \\
\hline Compressive strength, (psi) 28 day, Control & 5,780 & - \\
\hline Compressive strength, (psi) 3 day, Eucon AEA-92 & 3,680 & - \\
\hline Compressive strength, (psi) 7 day, Eucon AEA-92 & 4,130 & - \\
\hline Compressive strength, (psi) 28 day, Eucon AEA-92 & 5,550 & - \\
\hline Percent of Control, 3 days & 98 & $90 \%$ min \\
\hline Percent of Control, 7 days & 96 & $90 \%$ min \\
\hline Percent of Control, 28 day & 96 & $90 \%$ min \\
\hline
\end{tabular}




\subsection{Retarding (RET) admixture}

Eucon RET-75 formulated by the Euclid Chemical Company was the concrete water-reducing, set-retarding admixture proposed for the Charleroi L\&D concrete mixtures. The admixture is a synthetically produced liquid water-reducing and set-retarding agent for concrete. It does not contain calcium chloride or other potential corroding materials and may be used in the presence of aluminum or zinc metals. Abbreviated testing was performed in accordance to ASTM C494, Type B using a dosage of $5 \mathrm{oz}$ per $100 \mathrm{lb}$ of the RET-75 admixture. Water content, time of setting, and compressive strength results are provided in Table 22.

Table 22. Water content, compressive strength, and time of setting results comparing control and Eucon RET-75 admixture in concrete.

\begin{tabular}{|c|c|c|c|c|}
\hline Physical Analysis & Control & $\begin{array}{c}\text { RET-75 } \\
\text { Admixture }\end{array}$ & $\begin{array}{c}\% \text { of } \\
\text { Control }\end{array}$ & $\begin{array}{c}\text { ASTM C494 } \\
\text { Spec Limits }\end{array}$ \\
\hline Water Content (gal/yd ${ }^{3}$ ) & 27.8 & 25.6 & 92 & - \\
\hline $\begin{array}{c}\text { Compressive strength, } \\
\text { (psi) 3 day ASTM C39 }\end{array}$ & 3,750 & 4,090 & 109 & $90 \%$ (min) \\
\hline $\begin{array}{c}\text { Compressive strength, } \\
\text { (psi) 7 day ASTM C39 }\end{array}$ & 4,300 & 4,920 & 114 & $90 \%$ (min) \\
\hline $\begin{array}{c}\text { Compressive strength, } \\
\text { (psi) 28 day ASTM C39 }\end{array}$ & 5,780 & 6,780 & 117 & $90 \%$ (min) \\
\hline $\begin{array}{c}\text { Time of setting } \\
\text { (minutes), Initial } \\
\text { ASTM C403 }\end{array}$ & 240 & 290 & $\begin{array}{c}50 \text { min. } \\
\text { later than } \\
\text { control }\end{array}$ & $\begin{array}{c}\text { At least } 60 \text { min. } \\
\text { later and not } \\
\text { more than 210 } \\
\text { min later from } \\
\text { control }\end{array}$ \\
\hline $\begin{array}{c}\text { Time of setting } \\
\text { (minutes), Final } \\
\text { ASTM C403 }\end{array}$ & 320 & 375 & $\begin{array}{c}55 \text { min. } \\
\text { later than } \\
\text { control }\end{array}$ & $\begin{array}{c}\text { Not more than } \\
210 \text { min later } \\
\text { from control }\end{array}$ \\
\hline
\end{tabular}

\subsection{Water Reducing (WR) admixture}

Eucon WR formulated by the Euclid Chemical Company was the water reducing admixture proposed for the Charleroi L\&D concrete mixtures. The admixture is marketed as an aqueous solution of refined lignosulfonate that is free of any added chloride ions. It provides a more plastic and cohesive mix in the fresh concrete and better durability, reduced shrinkage, and less permeability in the hardened concrete. Abbreviated testing was performed in accordance to ASTM C494, Type A 
using a dosage of $4 \mathrm{fl}-\mathrm{oz} / \mathrm{cwt}$ of cementitious materials. Water content, time of setting, and compressive strength results are provided in Table 23.

Table 23. Water content, compressive strength, and time of setting results comparing control and Eucon WR admixture in concrete.

\begin{tabular}{|l|l|l|l|l|}
\hline \multicolumn{1}{|c|}{ Physical Analysis } & Control & $\begin{array}{l}\text { Eucon WR } \\
\text { Admixture }\end{array}$ & $\begin{array}{c}\text { \% of } \\
\text { Control }\end{array}$ & \multicolumn{1}{|c|}{$\begin{array}{c}\text { ASTM C494 } \\
\text { Spec Limits }\end{array}$} \\
\hline $\begin{array}{l}\text { Water Content } \\
\text { (gal/yd3) }\end{array}$ & 27.8 & 25.12 & 90 & $95 \%$ (max) \\
\hline $\begin{array}{l}\text { Compressive } \\
\text { strength, (psi) 3 day } \\
\text { ASTM C39 }\end{array}$ & 3,750 & 4,650 & 124 & $110 \%$ (min) \\
\hline $\begin{array}{l}\text { Compressive } \\
\text { strength, (psi) } 7 \text { day } \\
\text { ASTM C39 }\end{array}$ & 4,300 & 5,110 & 118 & $110 \%$ (min) \\
\hline $\begin{array}{l}\text { Compressive } \\
\text { strength, (psi) 28 day } \\
\text { ASTM C39 }\end{array}$ & 5,780 & 6,940 & 120 & $110 \%$ (min) \\
\hline $\begin{array}{l}\text { Time of setting } \\
\text { (minutes), Initial } \\
\text { ASTM C403 }\end{array}$ & 240 & 250 & 10 min & $\begin{array}{l}\text { Not more than } 60 \text { min } \\
\text { larlier nor } 90 \text { min } \\
\text { later than control }\end{array}$ \\
\hline $\begin{array}{l}\text { Time of setting } \\
\text { (minutes), Final } \\
\text { ASTM C403 }\end{array}$ & 320 & 330 & 10 min & $\begin{array}{l}\text { Not more than } 60 \text { min } \\
\text { earlier nor } 90 \text { min } \\
\text { later than control }\end{array}$ \\
\hline
\end{tabular}

\subsection{Anti-Washout (AW) admixture}

Eucon AWA formulated by the Euclid Chemical Company was the antiwashout (AW) admixture proposed for the Charleroi L\&D concrete mixtures. The admixture is marketed as a ready-to-use liquid designed to reduce the loss of cement and fine aggregate during the placement of underwater concrete. It greatly reduces or eliminates concrete bleed water and improves slump retention. Abbreviated testing was performed in accordance to ASTM C494 for Types S using a dosage of $25 \mathrm{fl}$-oz per $100 \mathrm{lb}$ of cementitious materials. Water content, time of setting, and compressive strength results are provided in Table 24. 
Table 24. Compressive strength and time of setting results of comparing control and Eucon AWA in concrete.

\begin{tabular}{|c|c|c|c|c|}
\hline Physical Analysis & Control & $\begin{array}{l}\text { Eucon AWA } \\
\text { Admixture }\end{array}$ & $\begin{array}{l}\% \text { of } \\
\text { Control }\end{array}$ & $\begin{array}{c}\text { ASTM C494 Spec } \\
\text { Limits }\end{array}$ \\
\hline $\begin{array}{c}\text { Compressive } \\
\text { strength, (psi) } 3 \text { day } \\
\text { ASTM C39 }\end{array}$ & 3,750 & 3,300 & 88 & $90 \%$ (min) \\
\hline $\begin{array}{c}\text { Compressive } \\
\text { strength, (psi) } 7 \text { day } \\
\text { ASTM C39 }\end{array}$ & 4,300 & 3,870 & 90 & $90 \%(\min )$ \\
\hline $\begin{array}{c}\text { Compressive } \\
\text { strength, (psi) } 28 \text { day } \\
\text { ASTM C39 }\end{array}$ & 5,780 & 5,260 & 91 & $90 \%(\min )$ \\
\hline $\begin{array}{l}\text { Time of setting } \\
\text { (minutes), Initial } \\
\text { ASTM C403 }\end{array}$ & 240 & 320 & $\begin{array}{l}80 \text { min } \\
\text { later }\end{array}$ & $\begin{array}{l}\text { Not more than } 60 \\
\text { min earlier nor } 90 \\
\text { min later than } \\
\text { control }\end{array}$ \\
\hline $\begin{array}{c}\text { Time of setting } \\
\text { (minutes), Final } \\
\text { ASTM C403 }\end{array}$ & 320 & 410 & $\begin{array}{l}90 \text { min } \\
\text { later }\end{array}$ & $\begin{array}{l}\text { Not more than } 60 \\
\text { min earlier nor } 90 \\
\text { min later than } \\
\text { control }\end{array}$ \\
\hline
\end{tabular}

\subsection{High Range Water Reducing (HRWR) admixture}

Eucon 37 formulated by the Euclid Chemical Company was the high range water reducing (HRWR) admixture proposed for the Charleroi L\&D concrete mixtures. The admixture is formulated to retain plastic consistency for 30-60 min after dosing depending on the initial slumps, dosage rates, and ambient temperature. It produces low water content and low water/cement ratio concrete allowing higher strengths. Abbreviated testing was performed in accordance to ASTM C494 criteria for a Type F admixture using a dosage of $16 \mathrm{fl}$-oz per $100 \mathrm{lb}$ of cementitious materials. Water content, time of setting, and compressive strength results are provided in Table 25. 
Table 25. Water content, compressive strength, and time of setting results comparing control and Eucon 37 admixture in concrete.

\begin{tabular}{|l|l|l|l|l|}
\hline \multicolumn{1}{|c|}{ Physical Analysis } & \multicolumn{1}{|c|}{ Control } & \multicolumn{1}{c|}{$\begin{array}{c}\text { Eucon 37 } \\
\text { Admixture }\end{array}$} & $\begin{array}{c}\text { \% of } \\
\text { Control }\end{array}$ & $\begin{array}{c}\text { ASTM C494 } \\
\text { Spec Limits }\end{array}$ \\
\hline $\begin{array}{l}\text { Water Content } \\
\text { (gal/yd }{ }^{3} \text { ) }\end{array}$ & 27.8 & 22.9 & 82 & $88 \%$ (max) \\
\hline $\begin{array}{l}\text { Compressive } \\
\text { strength, (psi) 3 day } \\
\text { ASTM C39 }\end{array}$ & 3,750 & 5,250 & 140 & $125 \%$ (min) \\
\hline $\begin{array}{l}\text { Compressive } \\
\text { strength, (psi) } 7 \text { day } \\
\text { ASTM C39 }\end{array}$ & 4,300 & 5,375 & 125 & $115 \%$ (min) \\
\hline $\begin{array}{l}\text { Compressive } \\
\text { strength, (psi) 28 day } \\
\text { ASTM C39 }\end{array}$ & 5,780 & 7,110 & 123 & $110 \%$ (min) \\
\hline $\begin{array}{l}\text { Time of setting } \\
\text { (minutes), Initial } \\
\text { ASTM C403 }\end{array}$ & 240 & 310 & $\begin{array}{l}70 \text { min } \\
\text { later }\end{array}$ & $\begin{array}{l}\text { Not more than } \\
60 \text { min earlier } \\
\text { nor 90 min later } \\
\text { than control }\end{array}$ \\
\hline $\begin{array}{l}\text { Time of setting } \\
\text { (minutes), Final } \\
\text { ASTM C403 }\end{array}$ & 320 & 395 & $\begin{array}{l}\text { Not min } \\
\text { later }\end{array}$ & $\begin{array}{l}\text { Not min earlier } \\
\text { nor 90 min later } \\
\text { than control }\end{array}$ \\
\hline
\end{tabular}




\section{Heat of Hydration}

Heat of hydration $(\mathrm{HOH})$ testing for mix designs $1,5,7$, and 10 provided by the Pittsburgh District were scaled to test in accordance to ASTM C1702 (ASTM 2017i), "Standard Test Method for Measurement of Heat of Hydration of Hydraulic Cementitious Materials Using Isothermal Conduction Calorimetry." This was done to create a heat of hydration signature for each mixture made with all available local materials and provide baseline information for future construction projects.

The four fly ash sources were tested independently in each mix design for a total of 16 tests to compare the efficacy to mitigate the heat generation. Table 26 provides a summary of the actual $\mathrm{HOH}$ mixture proportions tested.

Table 26. Batch quantities for heat of hydration in accordance to ASTM C1702.

\begin{tabular}{|c|c|c|c|c|}
\hline \multirow[b]{3}{*}{ Material } & \multicolumn{4}{|c|}{ Mixture ID } \\
\hline & Mix 1 & Mix 5 & $\operatorname{Mix} 7$ & Mix 10 \\
\hline & \multicolumn{4}{|c|}{ Mass (g) } \\
\hline Cement & 115.8 & 270.5 & 274.4 & 375 \\
\hline Class F Fly Ash & 109.6 & 106.2 & 150.8 & 125 \\
\hline GGBFS & 254.5 & 123.2 & 74.8 & - \\
\hline Silica Fume & 20.1 & - & - & - \\
\hline $\begin{array}{l}\text { Limestone } \\
\text { Powder }\end{array}$ & 107.5 & - & - & - \\
\hline Admixture & \multicolumn{4}{|c|}{ Volume (mL) } \\
\hline AEA & 0 & 0.739 & 1.131 & 0.346 \\
\hline WRA & 0 & 0 & 0 & 0 \\
\hline HRWRA & 6.244 & 0 & 0 & 0.593 \\
\hline RET & 1.361 & 0.646 & 0.495 & 0.346 \\
\hline AWA & 4.395 & 0 & 0 & 0 \\
\hline Water & \multicolumn{4}{|c|}{ Volume $(\mathrm{mL})$} \\
\hline Deionized & 195.5 & 258.5 & 230.0 & 235.0 \\
\hline
\end{tabular}

Each sample mixture was tested in duplicate runs for up to 28 days in accordance with ASTM C1702 (Method B, external mixing) using a TAMAIR isothermal conduction calorimetry manufactured by TA instruments. 
$\mathrm{HOH}$ results at 7 and 28 days are summarized in Table 27 and illustrated in Figure 6. Mix 1 showed the overall lowest heat generation while Mix 10 showed the overall highest heat generation. The lowest $\mathrm{HOH}$ was $11.1 \mathrm{~J} / \mathrm{g}$ and $16.0 \mathrm{~J} / \mathrm{g}$ at 7 and 28 days, respectively, produced by the Sammis fly ash in Mix 1. The highest $\mathrm{HOH}$ was $126.0 \mathrm{~J} / \mathrm{g}$ and $199.8 \mathrm{~J} / \mathrm{g}$ produced by the Longview fly ash in Mix 10. Results indicate there is not a significant difference in the four fly ashes tested within each unique mixture design.

Table 27. Average heat of hydration results at 7 and 28 days.

\begin{tabular}{|c|c|c|}
\hline Mixture ID & 7 days $(\mathrm{J} / \mathrm{g})$ & 28 days $(\mathrm{J} / \mathrm{g})$ \\
\hline Armstrong Type II Cement & 241.2 & 330.1 \\
\hline Mix 1: Sammis Fly Ash & 11.1 & 16.0 \\
\hline Mix 1: Ft. Martin Fly Ash & 11.9 & 19.6 \\
\hline Mix 1: Longview Fly Ash & 18.5 & 29.7 \\
\hline Mix 1: Brandon Shores Fly Ash & 16.6 & 25.4 \\
\hline Mix 5: Sammis Fly Ash & 106.2 & 184.7 \\
\hline Mix 5: Ft. Martin Fly Ash & 110.2 & 190.6 \\
\hline Mix 5: Longview Fly Ash & 106.8 & 191.7 \\
\hline Mix 5: Brandon Shores Fly Ash & 109.4 & 175.4 \\
\hline Mix 7: Sammis Fly Ash & 97.8 & 153.3 \\
\hline Mix 7: Ft. Martin Fly Ash & 104.4 & 160.9 \\
\hline Mix 7: Longview Fly Ash & 107.7 & 168.8 \\
\hline Mix 7: Brandon Shores Fly Ash & 108.6 & 165.4 \\
\hline Mix 10: Sammis Fly Ash & 120.8 & 190.4 \\
\hline Mix 10: Ft. Martin Fly Ash & 120.4 & 190.9 \\
\hline Mix 10: Longview Fly Ash & 126.03 & 199.8 \\
\hline Mix 10: Brandon Shores Fly Ash & 125.6 & 196.6 \\
\hline
\end{tabular}


Figure 6 . Heat of hydration for mix $1,5,7$, and 10 by fly ash at 7 and 28 days.
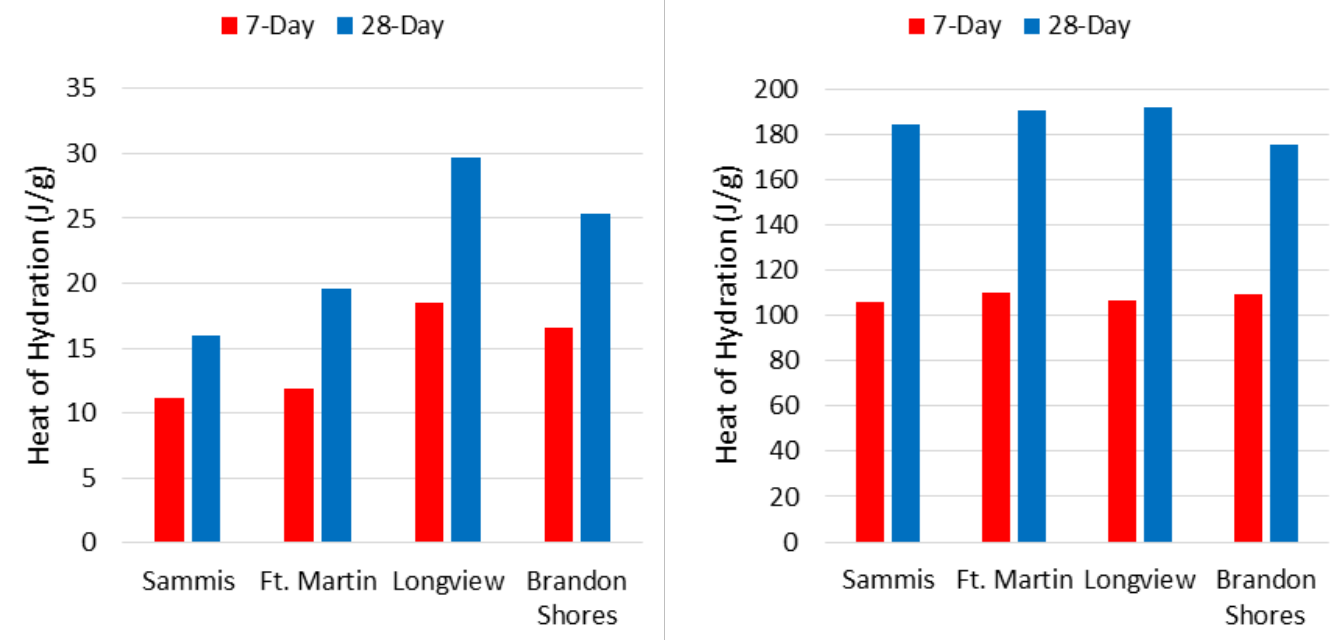

(a) Mix 1

(b) Mix 5
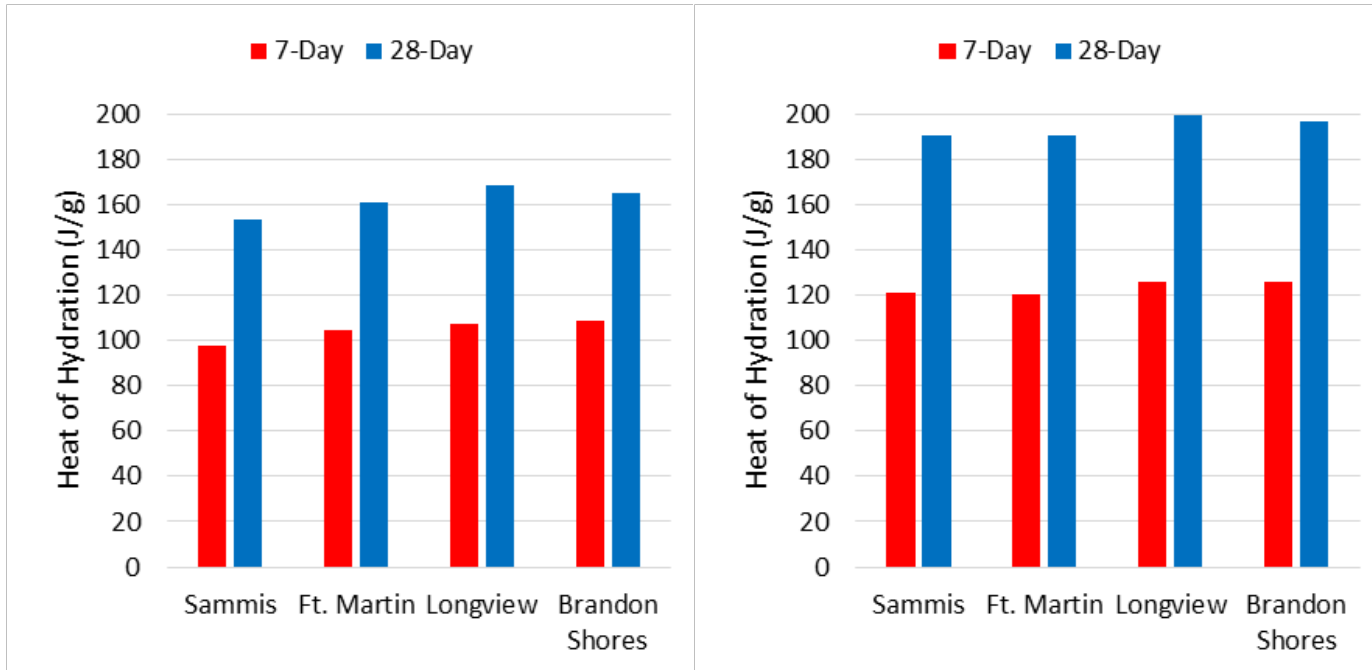

(c) Mix 7

(d) Mix 10 


\section{Summary and Conclusions}

The purpose of this investigation was to test potential construction materials provided by the USACE Pittsburgh District for the Charleroi Lock and Dam Monongahela River Reconstruction Project. Materials included three different coarse aggregate gradations, two fine aggregate sources, a type II (MH) cement, four class F fly ash sources, a slag cement, a silica fume, a limestone powder, five admixtures, and two water sources. Relevant conclusions from laboratory testing are summarized below. However, the suitability of each material and final acceptance will be at the District's discretion.

\section{Aggregate testing}

A total of nine ASTM procedures were conducted for the three proposed project aggregate sources (Hanson, Georgetown, and Shelley). Unless otherwise stated, aggregate quality requirements were based on the Charleroi construction specifications (USACE Pittsburgh District 2015). Test specific results indicate the following:

- Sieve analysis (ASTM C136)

The coarse and fine aggregates met all grading requirements with the following exceptions:

- Georgetown sand: $14 \%$ passing the \#50 (15-30\% criteria) and $2 \%$ passing the \#100 (5-10\% criteria)

○ Shelly sand: $12 \%$ passing the \#50 (15-30\% criteria) and $2 \%$ passing the \#100 (5-10\% criteria)

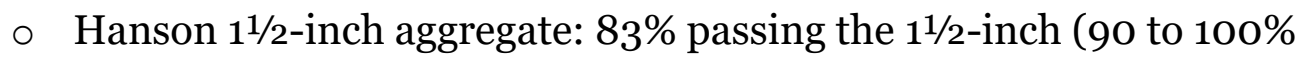
criteria) and $16 \%$ passing the 1 -inch (20 to $55 \%$ criteria)

- Hanson $3 / 4$-inch aggregate: $17 \%$ passing the $3 / 8$-inch (20 to $55 \%$ criteria)

- Specific Gravity and Absorption (ASTM C127/128) All aggregates met criteria specified for specific gravity and absorption.

- Materials Less than No. 200 Sieve (ASTM C117) All aggregates fell below the $1 \%$ maximum allowance for materials finer than No. 200 sieve with the exceptions of the $1^{1 / 2}$-inch Hanson aggregate(1.05\%) and 3-inch Hanson aggregate (1.01\%). 
- Organic Impurities (ASTM C40)

The organic plate results indicated both sands do not contain organic impurities at a concentration great enough to warrant further testing at this time.

- Soundness of Aggregates (ASTM C88)

All aggregates met the magnesium sulfate soundness requirement given in ASTM C88 of less than 18\% cumulative mass loss at 5 cycles.

- LA Abrasion (ASTM C131)

All aggregates met the abrasion requirement of less than $40 \%$ loss.

- Clay Lumps and Friable Particles (ASTM C142)

All aggregates met the quality requirements for clay lumps and friable particles (1.2\% maximum for fine aggregate; $2 \%$ maximum for coarse aggregate).

- Flat and Elongated Particles (ASTM D4791)

The flat and elongated particle results are less than the $12 \%$ maximum limiting criteria defined in the project specification.

- Lightweight Particles (ASTM C123)

All aggregates fell below the maximum percentage of chert and shale lightweight particles when tested with zinc bromide (2.4 specific gravity). All aggregates fell below the 1.0\% maximum percentage of lightweight particles when tested with zinc chloride (2.0 specific gravity) with the exception of $1.2 \%$ in the Georgetown sand.

\section{Freezing and thawing testing}

The freezing and thawing durability of one project coarse aggregate (Hanson), two project natural sand fine aggregates (Shelly and Georgetown), and one project mixture design (Mix 7) were determined in accordance to Procedure A of ASTM C666. The relative dynamic modulus ranged from a minimum of $61 \%$ to a maximum of $85 \%$, which is above the $60 \%$ requirement throughout the 300 freezing and thawing cycles for all specimens tested.

\section{Petrography testing}

Petrographic examination of the Hanson, Georgetown, and Shelly aggregates performed in accordance to ASTM C295 used X-ray diffraction patterns to identify and confirm the following mineral constituents:

- Hanson Aggregate

Calcite $\left(\mathrm{CaCO}_{3}\right)(55.7 \%)$, Quartz $\left(\mathrm{SiO}_{2}\right)(37.7 \%)$, micas Biotite 
$\left(\mathrm{K}(\mathrm{Mg}, \mathrm{Fe})_{3}\left(\mathrm{AlSi}_{3} \mathrm{O}_{10}\right)(\mathrm{F}, \mathrm{OH})_{2}\right)(5.1 \%)$, and Muscovite $\left.\left(\mathrm{KAl}_{2}\left(\mathrm{AlSi}_{3} \mathrm{O}_{10}\right)(\mathrm{F}, \mathrm{OH})_{2}\right)\right)(1.5 \%)$.

- Shelly Aggregate

Quartz $\left(\mathrm{SiO}_{2}\right)$ (69.0\%), Albite $\left(\mathrm{Na}\left(\mathrm{AlSi}_{3} \mathrm{O}_{8}\right)\right.$ (14.0\%), Graphite (C)

(6.2\%), Calcite $\left(\mathrm{CaCO}_{3}\right)(4.4 \%)$, micas Biotite

$\left(\mathrm{K}(\mathrm{Mg}, \mathrm{Fe})_{3}\left(\mathrm{AlSi}_{3} \mathrm{O}_{10}\right)(\mathrm{F}, \mathrm{OH})_{2}\right)(5.8 \%)$, and Muscovite

$\left.\left(\mathrm{KAl}_{2}\left(\mathrm{AlSi}_{3} \mathrm{O}_{10}\right)(\mathrm{F}, \mathrm{OH})_{2}\right)\right)(0.7 \%)$.

- Georgetown Aggregate

Quartz $\left(\mathrm{SiO}_{2}\right)$ (70.1\%), Albite $\left(\mathrm{Na}\left(\mathrm{AlSi}_{3} \mathrm{O}_{8}\right)(16.0 \%)\right.$, Calcite $\left(\mathrm{CaCO}_{3}\right)$

(5.6\%), micas Biotite $\left(\mathrm{K}(\mathrm{Mg}, \mathrm{Fe})_{3}\left(\mathrm{AlSi}_{3} \mathrm{O}_{10}\right)(\mathrm{F}, \mathrm{OH})_{2}\right)(5.2 \%)$, and Muscovite $\left.\left(\mathrm{KAl}_{2}\left(\mathrm{AlSi}_{3} \mathrm{O}_{10}\right)(\mathrm{F}, \mathrm{OH})_{2}\right)\right)(3.2 \%)$.

\section{Cementitious testing}

- Cement

The Armstrong cement produced by the Cabot, PA, mill met all ASTM

C150 specification requirements for a Type II moderate heat (MH) cement and was in compliance with the low-alkali (LA), false set (FS), and heat of hydration $(\mathrm{HH})$ criteria required by the Charleroi L\&D specifications.

- Fly Ash

Four class F fly ashes were tested in accordance to ASTM C618. The Brandon Shores class F fly ash from Curtis Bay, MD, met all specification requirements. The Longview fly ash from Maidsville, $\mathrm{WV}$, exceeded the $34 \%$ fineness allowed on a \#325 sieve with $38.6 \%$ retained. The Longview fly ash as well as the Sammis fly ash from Stratton, $\mathrm{OH}$, and the Fort Martin fly ash from Maidsville fell below the $75 \%$ strength activity index as suggested in ASTM C618. However, this test is a measure of reactivity with a given cement and is subject to variation depending on the source of fly ash and cement. The mass of the fly ash and cement specified for the strength activity index is not considered to be the proportion recommended for the concrete to be used in the work and acceptance is based on the District's determination.

- Slag Cement

The grade 100 slag cement produced by Argos-Essroc sources located in Middlebranch, OH, satisfied all ASTM C989 specification requirements. 
- Silica Fume

The microsilica grade $970 \mathrm{D}$ provided by Elkem Materials Inc. located in Pittsburgh, PA, conforms to all ASTM C1240 requirements.

- Limestone Powder

The Graymont limestone powder produced by the facility in Bellefonte, $\mathrm{PA}$, is primarily composed of calcium carbonate $\left(\mathrm{CaCo}_{3}\right)$. When tested in accordance to ASTM D546, 75.72\% of the material passed the No. 200 sieve opening. The material met the physical grading requirements of ASTM D242.

\section{Early stiffening of mortar}

The early development of stiffness in the working characteristics of the hydraulic-cement mortar designs of mix 1, 5, 7, and 10 were tested in accordance to ASTM C359. The four fly ash sources were evaluated independently with each mix design for a total of 16 tests. The early stiffening rate of the mortars ranged from a minimum of $5.3 \mathrm{~mm} / \mathrm{min}$ to a maximum of $7.2 \mathrm{~mm} / \mathrm{min}$ and the overall recovery ranged from a minimum of $96 \%$ to a maximum of $100 \%$. This indicates a low potential of early stiffening of the hydraulic mortars.

\section{Water quality testing}

Municipal water from the Charleroi water authority and well water from the left bank batch plant area were tested for water quality in accordance to CRD-C 40o. The well had not been circulating at the time the water sample was provided to the laboratory for testing. Both filtered and unfiltered municipal water samples met the criteria for iron, sulfate and chloride anions, and hydrogen-ion concentration. The unfiltered well water failed the limiting criteria for iron and chloride ions in the water. It is notable to mention that although the well water was included in the material tests, the unfiltered well water was never used as batch water in the Charleroi L\&D project.

\section{Chemical admixtures}

Based on abbreviated ASTM C494 testing for five chemical admixtures produced by the Euclid Chemical Company the following conclusions are made:

- Eucon AEA-92 met the compressive strength requirement in for a level of performance comparable to that of the reference concrete. 
- Eucon Retarder 75 met all water content, time of setting, and compressive strength physical requirements for a Type B admixture with the exception the initial time of setting. The test sample was only 50 min later than the control mixture and the allowable deviation is at least 60 min later.

- Eucon WR met all water content, time of setting, and compressive strength physical requirements for a Type A admixture.

- Eucon AWA met all compressive strength and time of setting physical requirements for a Type $S$ admixture.

- Eucon 37 met all water content, time of setting, and compressive strength physical requirements for a Type $\mathrm{F}$ admixture with the exception of the final time of setting. The test sample was 95 min later than the control mixture and the allowable deviation is no more than 90 min later.

\section{Heat of hydration}

The heat of hydration of the hydraulic-cement mortar designs of mix 1 , 5,7 , and 10 were tested up to 28 days in accordance to ASTM C1702. The four fly ash sources were evaluated independently with each mix design for a total of 16 tests. Mix 1 resulted the overall lowest heat generation while Mix 10 showed the overall highest heat generation. The lowest $\mathrm{HOH}$ was $11.1 \mathrm{~J} / \mathrm{g}$ and $16.0 \mathrm{~J} / \mathrm{g}$ at 7 and 28 days, respectively, produced by the Sammis fly ash in Mix 1 . The highest $\mathrm{HOH}$ was $126.0 \mathrm{~J} / \mathrm{g}$ and $199.8 \mathrm{~J} / \mathrm{g}$ produced by the Longview fly ash in Mix 10. Results indicate there is not a significant difference in the four fly ashes tested within each unique mixture design. 


\section{References}

American Society for Testing and Materials (ASTM). 2010. Standard test method for flat particles, elongated particles, or flat and elongated particles in coarse aggregate. Designation: D 4791-10. West Conshohocken, PA: ASTM International.

. 2012. Standard test method for X-ray spectrometric analysis of lime and limestone. Designation: C 1271-12. West Conshohocken, PA: ASTM International.

. 2013. Standard test method for early stiffening of hydraulic cement (mortar method). Designation: C 359-13. West Conshohocken, PA: ASTM International

2014a. Standard test method for resistance to degradation of small-size coarse aggregates by abrasion and impact in the Los Angeles Machine. Designation: C 131-14. West Conshohocken, PA: ASTM International.

2014b. Standard test method for mineral filler for bituminous paving mixtures". Designation: D 1242-14. West Conshohocken, PA: ASTM International.

. 2015a. Standard test method for relative density (specific gravity) and absorption of coarse aggregate. Designation: C 127-15. West Conshohocken, PA: ASTM International.

.2015b. Standard test method for relative density (specific gravity) and absorption of fine aggregate. Designation: C 128-15. West Conshohocken, PA: ASTM International.

2015c. Standard test method for slump of hydraulic cement concrete. Designation: C 143-15. West Conshohocken, PA: ASTM International.

. 2015d. Standard test method for resistance of concrete to rapid freezing and thawing. Designation: C 666-15. West Conshohocken, PA: ASTM International.

. 2015e. Standard specification for silica fume used in cementitious mixtures. Designation: C 1240-15. West Conshohocken, PA: ASTM International.

2016a. Standard test method for concrete aggregates. Designation: C 33-16. West Conshohocken, PA: ASTM International.

2016b. Standard test method for organic impurities in fine aggregates for concrete. Designation: C 40-16. West Conshohocken, PA: ASTM International.

2016c. Standard test method for sieve analysis of fine and coarse aggregates. Designation: C 136-14. West Conshohocken, PA: ASTM International.

. 2016d. Standard test method for making and curing concrete test specimens in the laboratory. Designation: C 192-16. West Conshohocken, PA: ASTM International.

2016e. Standard test method for air-entraining admixtures for concrete. Designation: C 260-16. West Conshohocken, PA: ASTM International. 
. 2016f. Standard test method for time of setting of concrete mixtures by penetration resistance. Designation: C 403-14. West Conshohocken, PA: ASTM International.

. 2017a. Standard test method for materials finer than (No. 20o) sieve. Designation: C 117-17. West Conshohocken, PA: ASTM International.

2017b. Standard test method for lightweight particles in aggregate. Designation: C 123-17. West Conshohocken, PA: ASTM International.

2017c. Standard test method for clay lumps and friable particles in aggregates. Designation: C 142-17. West Conshohocken, PA: ASTM International.

. 2017d. Standard test method for air content of freshly mixed concrete by the pressure method. Designation: C 231-17. West Conshohocken, PA: ASTM International.

. 2017e. Standard practices for petrographic examination of aggregates for concrete. Designation: C 295-17. West Conshohocken, PA: ASTM International.

2017f. Standard specification for chemical admixtures for concrete.

Designation: C494-17. West Conshohocken, PA: ASTM International.

2017g. Standard test method for sieve analysis of mineral filler for asphalt paving mixtures. Designation: D 546-17. West Conshohocken, PA: ASTM International.

.2017h. Standard specification for coal fly ash and raw or calcined natural pozzolan for use in concrete. Designation: C 618-17. West Conshohocken, PA: ASTM International.

2017i. Standard test method for measurement of heat of hydration of hydraulic cementitious materials using isothermal conduction calorimetry. Designation: C 1702-17. West Conshohocken, PA: ASTM International.

2018a. Standard test method for compressive strength of cylindrical concrete specimens. Designation: C 39-18. West Conshohocken, PA: ASTM International.

. 2018b. Standard test method for soundness of aggregates by use of sodium sulfate or magnesium sulfate. Designation: C 88-18. West Conshohocken, PA: ASTM International.

2018c. Standard specification for portland cement. Designation: C 150-18. West Conshohocken, PA: ASTM International.

2018d. Standard specification for slag cement for use in concrete and mortars. Designation: C 989-18. West Conshohocken, PA: ASTM International.

U.S. Army Corps of Engineers. 1963. Requirements for water for use in mixing or curing concrete. CRD-C 400-63. Washington, DC: USACE. 
USACE Pittsburgh District. 2015. Construction contract and specifications Volume 4 of 4 - Division o3 thru Division 16. Charleroi locks, contract 1; Charleroi locks and dams; Monongahela River, PA. RFP W911WN-04-R-0003. Pittsburgh, PA: U.S. Army Corps of Engineers. 


\section{Appendix A: Aggregate Test Results}


Hanson 3-in. Aggregate

\begin{tabular}{|c|c|c|c|c|c|c|c|c|}
\hline \multicolumn{9}{|c|}{ Summ ary of Aggreg ate T ests Report } \\
\hline \multirow{2}{*}{\multicolumn{3}{|c|}{ Material Description: }} & \multirow{2}{*}{ 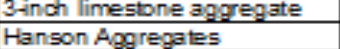 } & \multirow{2}{*}{\multicolumn{2}{|c|}{ Performing Organizaion: }} & \multirow{2}{*}{\multicolumn{3}{|c|}{$\begin{array}{l}\text { Geotechnical and Structures Lab } \\
\text { Concrete and Materials Branch }\end{array}$}} \\
\hline & & & & & & & & \\
\hline & & Location: & Connellswile, PA & \multicolumn{2}{|r|}{ Tested by } & \multicolumn{3}{|l|}{ R. Hardy } \\
\hline & & CMB Log in \#. & 150072 & & verwed by & J. Bumoug & hsM. Ramsegy & \\
\hline & Sponsoring & g Organization: & USACE Pittsburgh District, Low & ver Mon Area C & Ofine & & & \\
\hline & & Project & Charleroi Look and Dam Monor & ngahela River & Reconstruct & tion Project & & \\
\hline & & & ASTMC 136: Sieve & Analysis: & & & & \\
\hline & Rur & & Cumulative Percent & Run & & Cumula & five Percent & \\
\hline Sheve Stze & Mass Ret, g & $\%$ Ret & Pass & Mass Ret, gl & \%Ret & Ret & Pass & or rassing \\
\hline 3 in & 6010.6 & $7.57 \%$ & $92.43 \%$ & - & - & - & - & $92 \%$ \\
\hline $21 / 2$ in & 20593.0 & $25.96 \%$ & $66.50 \%$ & - & - & - & - & $66 \%$ \\
\hline 2 in & 37104.0 & $46.72 \%$ & $80.23 \%$ & - & - & - & - & $20 \%$ \\
\hline $11 / 2$ in & 14515.0 & $18.28 \%$ & $98.50 \%$ & - & - & - & - & $1 \%$ \\
\hline 1 in & 839.2 & $1.06 \%$ & $99.56 \%$ & - & - & - & - & $0 \%$ \\
\hline $3 / 4$ in & 157.9 & $0.20 \%$ & $99.76 \%$ & - & - & - & - & $0 \%$ \\
\hline $1 / 2 \mathrm{n}$ & 0.0 & $0.00 \%$ & $99.76 \%$ & - & - & - & - & $0 \%$ \\
\hline $3 / 8 \mathrm{n}$ & 0.0 & $0.00 \%$ & $99.76 \%$ & - & - & - & - & $0 \%$ \\
\hline No. 4 & 0.0 & $0.00 \%$ & $99.78 \%$ & - & - & - & - & $0 \%$ \\
\hline No. 8 & 0.0 & $0.00 \%$ & $99.76 \%$ & - & - & - & - & $0 \%$ \\
\hline Pan & 190.3 & $0.24 \%$ & $100.00 \%$ & & & & & $0 \%$ \\
\hline Total & 79409.9 & $100.00 \%$ & & & & & & $0 \%$ \\
\hline & & & ASTM C 117: Minus 75: & um (No. 200$)$ & & & & \\
\hline ODMass, g & 20195.4 & Mass At.g & $19982.5 \quad$ Mass Los5, g & 212.9 & & & \% Los: & $1.05 \%$ \\
\hline & & & ASTM C 127: Bulk Spedic Gr & ravity \& Absorp & Dton: & & & \\
\hline & & & & & & Ryn 1 & Run 2 & Aig \\
\hline & & $\mathrm{SSD}$ & Mass in Air, g & & & 19039.6 & 21066.6 & \\
\hline & & SSD N & Mass in Water, g & & & \begin{tabular}{ll|}
11945.1 \\
\end{tabular} & 13262.1 & \\
\hline & & Displ & laced Water, g & & & 7094.5 & 7794.5 & \\
\hline & & & ater Temp C & & & 23.5 & 23.5 & \\
\hline & & elafive Density/ & Bulk Specific Gravit) (SSD) & & & 2.684 & 2.701 & 2.69 \\
\hline & & Ove & E Dry Mass, g & & & 18992.1 & $20 \operatorname{sos} 2.1$ & \\
\hline & & Moi & isture Loss, g & & & 47.5 & 124.5 & \\
\hline & & & Absorption & & & $0.25 \%$ & $0.59 \%$ & $0.42 \%$ \\
\hline & & & STM C 88 Magnesium Sulfate & Soundness (5) & cycles): & & & \\
\hline & Gradation > 5\% & ODMass,g & Mass Aft, g Mass Loss, g & $\%$ Loss & Wted \% & No. PCS & No. Flaked & \\
\hline 3 in & $7.57 \%$ & 8048.0 & \begin{tabular}{ll|}
6039.3 & 8.7 \\
\end{tabular} & 0.00 & $0.0 \%$ & & & \\
\hline $21 / 2$ in & $25.93 \%$ & 63621 & 6356.6 & 0.00 & $0.0 \%$ & & & \\
\hline 2 in & $46.72 \%$ & 2908.2 & 2906.3 & 0.00 & $0.0 \%$ & & & \\
\hline $11 / 2$ in & $18.28 \%$ & 1966.1 & 1919.2 & 0.02 & $0.4 \%$ & 12 & 3 & \\
\hline 1 in & $1.08 \%$ & 1968.1 & 1919.2 & 0.02 & $0.0 \%$ & & & \\
\hline $3 / 4$ n & $0.20 \%$ & 1968.1 & 1919.2 & 0.02 & $0.0 \%$ & & & \\
\hline $1 / 2 \mathrm{n}$ & $0.00 \%$ & 1966.1 & 1919.2 & 0.02 & $0.0 \%$ & & & \\
\hline $3 / 8 \mathrm{n}$ & $0.00 \%$ & 1968.1 & 1919.2 & 0.02 & $0.0 \%$ & & & \\
\hline No. 4 & $0.00 \%$ & 1966.1 & 1919.2 & 0.02 & $0.0 \%$ & & & \\
\hline Total & $99.76 \%$ & & & & $0.5 \%$ & & & $0.5 \%$ \\
\hline & & $\underline{\bar{A}}$ & MC 123 Light WeightPartides & d Plecess in. & Aggregate & & & \\
\hline ASTM C 123: & -ightweight Piece & & ZncBromide 2.40 sp.gr. & & No mafl. ligh & her than 2 & .00 sp.g. & \\
\hline ODMass, g & 9843.9 & Ret Mass, g & 9843.9 Mass Loss, $\mathrm{g}$ & & $\%$ LOSS: & $0.00 \%$ & & $0.0 \%$ \\
\hline & & ASTMC & C131 or C 535 Los Angeles Abr & rasion Resistar & noe (500 rel & & & \\
\hline Grading: & 1 & ODMass, g & 7537.5 RetMass, g & 6068.2 & & & \%Loss: & $11.58 \%$ \\
\hline & & & ASTMC 142: ClayLLumps \& & Friable Partid: & & & & \\
\hline & Gradation $>5 \%$ & ODMass,g & Mass At, g Mass Loss,g & \begin{tabular}{l|l} 
Loss & 1
\end{tabular} & Wfed $\%$ & & & \\
\hline 3 in & $7.57 \%$ & 5265.5 & 5259.8 & 0.00 & $0.0 \%$ & & & \\
\hline $21 / 2 \mathrm{n}$ & $25.93 \%$ & 5373.9 & 5370.1 & 0.00 & $0.0 \%$ & & & \\
\hline 2 in & $46.72 \%$ & 5154.6 & 5150.9 & 0.00 & $0.0 \%$ & & & \\
\hline $11 / 2 n$ & $18.28 \%$ & 3173.1 & 3170.1 & 0.00 & $0.0 \%$ & & & \\
\hline 1 in & $1.06 \%$ & 3173.1 & 3170.1 & 0.00 & $0.0 \%$ & & & \\
\hline $3 / 4$ in & $0.20 \%$ & 3173.1 & 3170.1 & 0.00 & $0.0 \%$ & & & \\
\hline $1 / 2$ in & $0.00 \%$ & 1.0 & 1.0 & 0.00 & $0.0 \%$ & & & \\
\hline 3.8 in & $0.00 \%$ & 1.0 & 1.0 & 0.00 & $0.0 \%$ & & & \\
\hline No. 4 & $0.00 \%$ & 1.0 & 1.0 & 0.00 & $0.0 \%$ & & & \\
\hline Total & $99.76 \%$ & & & & $0.1 \%$ & & & $0.1 \%$ \\
\hline & & & ASTM D 4791 Flat or Elond & gated Parbiles & & & & \\
\hline 3:1 Rafio & iradation $>10 \%$ & Pcs Before & Elong Pas & FBE P $\propto S$ & $\%$ F,ER,FE & Wied \% & & \\
\hline 3 in & $7.57 \%$ & 100 & 1 & 2 & 0.03 & $0.2 \%$ & & \\
\hline $21 / 2 n$ & $25.93 \%$ & 103 & 0 & 9 & 0.12 & $3.0 \%$ & & \\
\hline 2 in & $46.72 \%$ & 102 & 0 & 6 & 0.11 & $5.0 \%$ & & \\
\hline $11 / 2 n$ & $18.28 \%$ & 108 & 0 & 7 & 0.08 & $1.6 \%$ & & \\
\hline 1 in & $1.06 \%$ & 100 & 0 & 0 & 0.00 & $0.0 \%$ & & \\
\hline $3 / 4$ in & $0.20 \%$ & 100 & 0 & 0 & 0.00 & $0.0 \%$ & & \\
\hline $1 / 2$ in & $0.00 \%$ & 100 & 0 & 0 & 0.00 & $0.0 \%$ & & \\
\hline 3.8 in & $0.00 \%$ & 100 & 0 & 0 & 0.00 & $0.0 \%$ & & \\
\hline No. 4 & $0.00 \%$ & 100 & 0 & 0 & 0.00 & $0.0 \%$ & & \\
\hline Total & $99.76 \%$ & & & & & $9.8 \%$ & & $9.8 \%$ \\
\hline
\end{tabular}




\section{Hanson 11/2-in. Aggregate}

\begin{tabular}{|c|c|c|c|c|c|c|c|c|c|}
\hline \multicolumn{10}{|c|}{ Summ ary of Aggreg ate Tests Report } \\
\hline & Mate & ial Description & \multirow{2}{*}{\multicolumn{2}{|c|}{\begin{tabular}{|l|}
1 1/2-inch aggregate \\
Hanson Aggregates \\
\end{tabular}}} & \multirow{2}{*}{\multicolumn{2}{|c|}{$\begin{array}{l}\text { Performing } \\
\text { Organizaion: }\end{array}$}} & \multirow{2}{*}{\multicolumn{3}{|c|}{$\begin{array}{l}\text { Geotechnical and Structures Lab } \\
\text { Concrete and Materials Branch }\end{array}$}} \\
\hline & & Source: & & & & & & & \\
\hline & & Location: & \multicolumn{2}{|c|}{ Connells ville, $\mathrm{PA}$} & \multicolumn{2}{|r|}{ Tested by } & \multicolumn{3}{|l|}{ R Hardy } \\
\hline & & CMB Log in $\#:$ & 150071 & & & evewed by. & J. Burrough & hs.M. Ramse & \\
\hline & Sponsorin & g Organization: & USACE Pittsbur & Igh District, Lov & ver Mon Area & Office & & & \\
\hline & & Project| & Charleroi Lodk a & and Dam Mono & ngahela River & ir Reconstruc & ction Project & & \\
\hline & & & ASTM & C 136: Sieve $A$ & nalysis: & & & & \\
\hline Sieve Sire & & n1 & Cumulativ & ve Percent & Run & $\mathrm{n} 2$ & Cumulativ & E Percent & $A \vee g \%$ \\
\hline Sleve size & Mass Ret, g & \%Ret & Ret. & Pass & Mass Ret. g & $\%$ Ret & Ret & Pass & Passing \\
\hline 3 in & 0.0 & $0.00 \%$ & $0.00 \%$ & $100.00 \%$ & 0.0 & $0.00 \%$ & $0.00 \%$ & $100.00 \%$ & $100 \%$ \\
\hline $21 / 2 \mathrm{n}$ & 0.0 & $0.00 \%$ & $0.00 \%$ & $100.00 \%$ & 0.0 & $0.00 \%$ & $0.00 \%$ & $100.00 \%$ & $100 \%$ \\
\hline 2 in & 0.0 & $0.00 \%$ & $0.00 \%$ & $100.00 \%$ & 0.0 & $0.00 \%$ & $0.00 \%$ & $100.00 \%$ & $100 \%$ \\
\hline $11 / 2 n$ & 2985.3 & $19.55 \%$ & $19.55 \%$ & $80.45 \%$ & 21772 & $13.89 \%$ & $13.89 \%$ & $86.11 \%$ & $83 \%$ \\
\hline 1 in & 9979.0 & $65.33 \%$ & $84.88 \%$ & $15.12 \%$ & 10704.8 & $68.31 \%$ & $82.21 \%$ & $17.79 \%$ & $16 \%$ \\
\hline $3 / 4$ in & 1841.1 & $12.05 \%$ & $96.93 \%$ & $3.07 \%$ & 2268.0 & $14.47 \%$ & $96.68 \%$ & $3.32 \%$ & $3 \%$ \\
\hline $1 / 2$ in & 398.0 & $2.61 \%$ & $99.54 \%$ & $0.48 \%$ & 440.0 & $2.81 \%$ & $99.49 \%$ & $0.51 \%$ & $0 \%$ \\
\hline 3.8 in & 22.7 & $0.15 \%$ & $99.69 \%$ & $0.31 \%$ & 32.0 & $0.20 \%$ & $99.69 \%$ & $0.31 \%$ & $0 \%$ \\
\hline Pan & 47.9 & $0.31 \%$ & $100.00 \%$ & $0.00 \%$ & 47.9 & $0.31 \%$ & $100.00 \%$ & $0.00 \%$ & $0 \%$ \\
\hline Total & 15274.0 & $100.00 \%$ & & & 15609.8 & $100.00 \%$ & & & \\
\hline & & & ASTM C 1 & 117: Minus $75 u r$ & $\mathrm{~m}(\mathrm{~N} 0.200)$ & & & & \\
\hline OD Mass, g & 19605.7 & Mass Aft.g & 19399.0 & Mass Loss, g & 208.7 & & & $\%$ LOSE: & $1.06 \%$ \\
\hline & & & ASTM C 127: Bu & ulk Spedifc Gra & vity\&:Absorpt & fion: & & & \\
\hline & & & & & & & Run 1 & Run 2 & Avg \\
\hline & & SSD & DMass in Air, g & & & & 5321.2 & 56052 & \\
\hline & & SSDM & Mass in Water, g & & & & 33.30 .8 & 3514.8 & \\
\hline & & Displ: & laced Water, g & & & & 1990.4 & 2090.4 & \\
\hline & & & later Temp C & & & & 23.5 & 23.5 & \\
\hline & & lative Density(: & Buk Specifc Gr & ravity (SSD) & & & 2.673 & 2.681 & 2.68 \\
\hline & & Over & en DryMass, g & & & & 5303.3 & 5575.5 & \\
\hline & & & isture Loss, g & & & & 17.9 & 29.7 & \\
\hline & & & Absorption & & & & $0.34 \%$ & $0.53 \%$ & $0.44 \%$ \\
\hline & & & STM C 88 Magne & sium Sulfate So & oundness $(5 \mathrm{c}$ & ydes): & & & \\
\hline $01 / 15 \quad 1.5^{\prime}$ & & & & & & & & & \\
\hline & Gradation $>5 \%$ & OD Mass, gl & Mass Aft, gl & Mass Loss, g & \% Loss & Whted \% & \begin{tabular}{|l|} 
No. PCS \\
\end{tabular} & No. Flaked & \\
\hline $21 / 2 n$ & $0.00 \%$ & 1.0 & 1.0 & 0.0 & 0.00 & $0.0 \%$ & & & \\
\hline 2 in & $0.89 \%$ & 4738.9 & 4708.8 & 30.1 & 0.01 & $0.0 \%$ & & & \\
\hline $11 / 2 n$ & $35.87 \%$ & 4738.9 & 4708.8 & 30.1 & 0.01 & $0.2 \%$ & 34 & 4 & \\
\hline 1 in & $51.25 \%$ & 983.1 & 981.2 & 1.9 & 0.00 & $0.1 \%$ & & & \\
\hline $3 / 4$ in & $9.46 \%$ & 473.3 & 272.0 & 201.3 & 0.43 & $4.0 \%$ & & & \\
\hline $1 / 2$ in & $2.04 \%$ & 473.3 & 2720 & 201.3 & 0.43 & $0.9 \%$ & & & \\
\hline 3.8 in & $0.12 \%$ & 473.3 & 2720 & 201.3 & 0.43 & $0.0 \%$ & & & \\
\hline No. 4 & $0.11 \%$ & 473.3 & 2720 & 201.3 & 0.43 & $0.0 \%$ & & & \\
\hline No. 8 & $0.02 \%$ & 473.3 & 2720 & 201.3 & 0.43 & $0.0 \%$ & & & \\
\hline Total & $99.75 \%$ & & & & & $5.3 \%$ & & & $5.3 \%$ \\
\hline & & ASTM & $1 \mathrm{C} 123 \mathrm{Lght} \mathrm{We}$ & EightParbies a & nd Pieces in $A$ & Agpregate & & & \\
\hline Bromide 2.40 & sp.gr & & No mat1. & lighter than 2.0 & osp.gr. & & & & \\
\hline OD Mass, g & 6382.5 & Ret Mass, g & 6354.6 & Mass Loss, g & 27.9 & & & $\%$ LOSE: & $0.44 \%$ \\
\hline & & ASTM C 1 & 131 or $C 535 \mathrm{Lo}$ & os Angeles Abra & sion Resistan & $10 \mathrm{f}(500 \mathrm{rev})$. & & & \\
\hline Grading: & $\bar{A}$ & OD Mass, g. & 5068.2 & Ret Mass, g & 3921.4 & & & \%Loss: & $22.47 \%$ \\
\hline & & & ASTMC 142: & Claylumps \& F & riable Partide & & & & \\
\hline & Gradation $>5 \%$ & OD Mass, g & Mass Aft, gl & Mass Loss, g & $\%$ Loss & Wted \% & & & \\
\hline $21 / 2 n$ & $0.00 \%$ & 1.0 & 1.0 & $\overline{0.0}$ & 0.00 & $0.0 \%$ & & & \\
\hline 2 in & $0.89 \%$ & 3173.1 & 3170.1 & 3.0 & 0.00 & $0.0 \%$ & & & \\
\hline $11 / 2 \mathrm{n}$ & $35.87 \%$ & 3173.1 & 3170.1 & 3.0 & 0.00 & $0.0 \%$ & & & \\
\hline 1 in & $51.25 \%$ & 3009.4 & 3006.5 & 2.9 & 0.00 & $0.0 \%$ & & & \\
\hline $3 / 4$ in & $9.46 \%$ & 3523.7 & 3520.3 & 3.4 & 0.00 & $0.0 \%$ & & & \\
\hline $1 / 2$ in & $2.04 \%$ & 3523.7 & 3520.3 & 3.4 & 0.00 & $0.0 \%$ & & & \\
\hline 3,8 in & $0.12 \%$ & 3523.7 & 3520.3 & 3.4 & 0.00 & $0.0 \%$ & & & \\
\hline No. 4 & $0.11 \%$ & 3523.7 & 3520.3 & 3.4 & 0.00 & $0.0 \%$ & & & \\
\hline Total & $99.63 \%$ & & & & & $0.1 \%$ & & & $0.1 \%$ \\
\hline & & & ASTIMD 479 & Trfat or Elong: & Ed Partcles: & & & & \\
\hline 3:1 Ratio & & & & & & & & & \\
\hline & Gradation $>10^{9}$ & Pos Before & Flat Pos & Elong $\mathrm{P} c s$ & FBE Pos & $\%$ F,E\&FE & \begin{tabular}{|l|} 
Wted $\%$ \\
\end{tabular} & & \\
\hline $21 / 2 n$ & $0.00 \%$ & 100 & 0 & 0 & 0 & 0.00 & $0.0 \%$ & & \\
\hline 2 in & $0.89 \%$ & 100 & 0 & 0 & 0 & 0.00 & $0.0 \%$ & & \\
\hline $11 / 2 \mathbf{n}$ & $35.87 \%$ & 114 & 2 & 0 & 8 & 0.09 & $3.1 \%$ & & \\
\hline 1 in & $51.25 \%$ & 106 & 1 & 1 & 8 & 0.10 & $4.9 \%$ & & \\
\hline $3 / 4$ in & $9.46 \%$ & 100 & 0 & 0 & 0 & 0.00 & $0.0 \%$ & & \\
\hline $1 / 2$ in & $2.04 \%$ & 100 & 0 & 0 & 0 & 0.00 & $0.0 \%$ & & \\
\hline $3 / 8$ in & $0.12 \%$ & 100 & 0 & 0 & 0 & 0.00 & $0.0 \%$ & & \\
\hline No. 4 & $0.11 \%$ & 100 & 0 & 0 & 0 & 0.00 & $0.0 \%$ & & \\
\hline Total & $9.73 \%$ & & & & & & $8.0 \%$ & & $8.0 \%$ \\
\hline
\end{tabular}




\section{Hanson 3/4-in. Aggregate}

\begin{tabular}{|c|c|c|c|c|c|c|c|c|c|}
\hline \multicolumn{10}{|c|}{ Summary of Aggregate Tests Report } \\
\hline \multicolumn{3}{|c|}{ Material Description: } & \multirow{2}{*}{\multicolumn{2}{|c|}{\begin{tabular}{|l|} 
3/4-inch limestone aggregate \\
Hanson Agaregates
\end{tabular}}} & \multirow{2}{*}{\multicolumn{2}{|c|}{$\begin{array}{l}\text { Performing } \\
\text { Organizaion: }\end{array}$}} & \multirow{2}{*}{\multicolumn{3}{|c|}{$\begin{array}{l}\text { Geotechnical and Structures Lab } \\
\text { Concrete and Materials Branch }\end{array}$}} \\
\hline & & Source: & & & & & & & \\
\hline & & Location: & & & \multicolumn{2}{|r|}{ Tested by: } & \multicolumn{3}{|l|}{ R. Hardy } \\
\hline & & CMB Log in \#. & 150070 & & & Reviewed by: & J. Burroug & hs/M. Ram & \\
\hline & Sponsorin & g Organization: & USACE Pittsb & urgh District, Lo & ower Mon Are & a Office & & & \\
\hline & & Project: & Charleroi Lock & and Dam Mono & ongahela River & r Reconstruc & ction Proje & & \\
\hline & & & ASTM C & 136: Sieve Ana & aly sis: & & & & \\
\hline & Run & & Cumulativ & ve Percent & Run & In 2 & Cumulativ & e Percent & Avg \% \\
\hline Sieve Size & Mass Ret, g & $\%$ Ret. & Ret. & Pass & Mass Ret, g & $\%$ Ret. & Ret. & Pass & Passing \\
\hline 3 in & 0.0 & $0.00 \%$ & $0.00 \%$ & $100.00 \%$ & 0.0 & $0.00 \%$ & $0.00 \%$ & $100.00 \%$ & $100 \%$ \\
\hline $21 / 2$ in & 0.0 & $0.00 \%$ & $0.00 \%$ & $100.00 \%$ & 0.0 & $0.00 \%$ & $0.00 \%$ & $100.00 \%$ & $100 \%$ \\
\hline 2 in & 0.0 & $0.00 \%$ & $0.00 \%$ & $100.00 \%$ & 0.0 & $0.00 \%$ & $0.00 \%$ & $100.00 \%$ & $100 \%$ \\
\hline $11 / 2$ in & 0.0 & $0.00 \%$ & $0.00 \%$ & $100.00 \%$ & 0.0 & $0.00 \%$ & $0.00 \%$ & $100.00 \%$ & $100 \%$ \\
\hline 1 in & 0.0 & $0.00 \%$ & $0.00 \%$ & $100.00 \%$ & 0.0 & $0.00 \%$ & $0.00 \%$ & $100.00 \%$ & $100 \%$ \\
\hline $3 / 4$ in & 265.1 & $3.21 \%$ & $3.21 \%$ & $96.79 \%$ & 255.1 & $3.07 \%$ & $3.07 \%$ & $96.93 \%$ & $97 \%$ \\
\hline $1 / 2$ in & 4418.7 & $53.44 \%$ & $56.65 \%$ & $43.35 \%$ & 4022.8 & $48.44 \%$ & $51.51 \%$ & $48.49 \%$ & $46 \%$ \\
\hline $3 / 8$ in & 2306.2 & $27.89 \%$ & $84.54 \%$ & $15.46 \%$ & 2544.6 & $30.64 \%$ & $82.15 \%$ & $17.85 \%$ & $17 \%$ \\
\hline No. 4 & 1017.2 & $12.30 \%$ & $96.85 \%$ & $3.15 \%$ & 1076.2 & $12.96 \%$ & $95.10 \%$ & $4.90 \%$ & $4 \%$ \\
\hline No. 8 & 177.5 & $2.15 \%$ & $98.99 \%$ & $1.01 \%$ & 285.8 & $3.44 \%$ & $98.55 \%$ & $1.45 \%$ & $1 \%$ \\
\hline Pan & 83.1 & $1.01 \%$ & $100.00 \%$ & & 120.8 & $1.45 \%$ & $100.00 \%$ & & \\
\hline Total & 8267.8 & $100.00 \%$ & & & 8305.3 & & & & \\
\hline & & & ASTM C 11 & 7: Minus $75 \mathrm{um}$ & (No. 200) & & & & \\
\hline OD Mass, $\mathrm{g}$ & 9427.7 & Mass Aft, $g$ & 9359.2 & Mass Loss, g & 68.5 & & & \% Loss: & $0.73 \%$ \\
\hline & & & STM C 127: Bull & k Specific Gravit & ity \& Absorpti & ion: & & & \\
\hline & & & & & & & Run 1 & Run 2 & Avg \\
\hline & & SSD & Mass in Air, $\mathrm{g}$ & & & & 3142.6 & 3529.7 & \\
\hline & & SSD M & ass in Water, $\mathrm{g}$ & & & & 1965.1 & 2207.5 & \\
\hline & & Displa & aced Water, g & & & & 1177.5 & 1322.2 & \\
\hline & & Wa & ter Temp C & & & & 22.7 & 22.7 & \\
\hline & Rel: & lative Density (B & Bulk Specific Gr & avity)(SSD) & & & 2.669 & 2.670 & 2.67 \\
\hline & & Oven & Dry Mass, $\mathrm{g}$ & & & & 3123.4 & 3508.8 & \\
\hline & & Mois & sture Loss, $\mathrm{g}$ & & & & 19.2 & 20.9 & \\
\hline & & & bsorption & & & & $0.61 \%$ & $0.60 \%$ & $0.61 \%$ \\
\hline & & ASTI & M C 88 Magnesi & um Sulfate Sou & undness $(5 \mathrm{cy}$ & ycles): & & & \\
\hline & Gradation $>5 \%$ & OD Mass, $\mathrm{g}$ & Mass Aft, $\mathrm{g}$ & Mass Loss, $\mathrm{g}$ & $\%$ Loss & Wt'ed \% & & & \\
\hline $21 / 2$ in & $0.00 \%$ & 1.0 & 1.0 & 0.0 & 0.00 & $0.0 \%$ & & & \\
\hline 2 in & $0.00 \%$ & 1.0 & 1.0 & 0.0 & 0.00 & $0.0 \%$ & & & \\
\hline $11 / 2$ in & $0.00 \%$ & 1.0 & 1.0 & 0.0 & 0.00 & $0.0 \%$ & & & \\
\hline 1 in & $0.00 \%$ & 1.0 & 1.0 & 0.0 & 0.00 & $0.0 \%$ & & & \\
\hline $3 / 4$ in & $3.21 \%$ & 674.4 & 668.0 & 6.4 & 0.01 & $0.0 \%$ & & & \\
\hline $1 / 2$ in & $53.44 \%$ & 674.4 & 668.0 & 6.4 & 0.01 & $0.5 \%$ & & & \\
\hline $3 / 8$ in & $27.89 \%$ & 1004.6 & 978.6 & 26.0 & 0.03 & $0.7 \%$ & & & \\
\hline No. 4 & $12.30 \%$ & 280.9 & 280.9 & 0.0 & 0.00 & $0.0 \%$ & & & \\
\hline No. 8 & $2.15 \%$ & 280.9 & 280.9 & 0.0 & 0.00 & $0.0 \%$ & & & \\
\hline Total & $98.99 \%$ & & & & & $1.3 \%$ & & & $1.3 \%$ \\
\hline & & ASTM C & 123 Light Weic & ght Particles an & d Pieces in A & Aggregate & & & \\
\hline Zinc Bromide & 40 sp.gr. & & No mat'l. lighte & $r$ than $2.00 \mathrm{sp} . \mathrm{c}$ & & & & & \\
\hline OD Mass, $\mathrm{g}$ & 3004.0 & Ret Mass, g & 2959.7 & Mass Loss, $\mathrm{g}$ & 44.3 & $\%$ Loss: & $1.47 \%$ & & $1.5 \%$ \\
\hline & & ASTI & M C131 or C535 & LA Abrasion $R$ & Resistance (50 & $00 \mathrm{rev}$ ) & & & \\
\hline Grading: & $\mathrm{B}$ & OD Mass, $\mathrm{g}$ & 5009.9 & Ret Mass, $\mathrm{g}$ & 3903.8 & \% Loss: & $22.08 \%$ & & $22.1 \%$ \\
\hline & & & ASTM C 142: Cl & ay Lumps \& Fri & iable Particles & & & & \\
\hline & Gradation $>5 \%$ & OD Mass, $\mathrm{g}$ & Mass Aft, $\mathrm{g}$ & Mass Loss, $\mathrm{g}$ & $\%$ Loss & Wt'ed \% & & & \\
\hline $21 / 2$ in & $0.00 \%$ & 1.0 & 1.0 & 0.0 & 0.00 & $0.0 \%$ & & & \\
\hline 2 in & $0.00 \%$ & 1.0 & 1.0 & 0.0 & 0.00 & $0.0 \%$ & & & \\
\hline $11 / 2$ in & $0.00 \%$ & 1.0 & 1.0 & 0.0 & 0.00 & $0.0 \%$ & & & \\
\hline 1 in & $0.00 \%$ & 1.0 & 1.0 & 0.0 & 0.00 & $0.0 \%$ & & & \\
\hline $3 / 4$ in & $3.21 \%$ & 2037.7 & 2035.4 & 2.3 & 0.00 & $0.0 \%$ & & & \\
\hline $1 / 2$ in & $53.44 \%$ & 2037.7 & 2035.4 & 2.3 & 0.00 & $0.1 \%$ & & & \\
\hline $3 / 8$ in & $27.89 \%$ & 2001.1 & 1999.2 & 1.9 & 0.00 & $0.0 \%$ & & & \\
\hline No. 4 & $12.30 \%$ & 1007.0 & 1002.4 & 4.6 & 0.00 & $0.1 \%$ & & & \\
\hline Total & $96.85 \%$ & & & & & $0.1 \%$ & & & $0.1 \%$ \\
\hline & & & ASTM D 4791 & Flat or Elongat & ted Particles: & & & & \\
\hline 3:1 Ratio & Gradation $>10 \%$ & Pcs Before & Flat Pcs & Elong PCs & F\&E PCS & $\%$ F,E\&FE & Wt'ed \% & & \\
\hline $21 / 2$ in & $0.00 \%$ & 100 & 0 & 0 & 0 & 0.00 & $0.0 \%$ & & \\
\hline 2 in & $0.00 \%$ & 100 & 0 & 0 & 0 & 0.00 & $0.0 \%$ & & \\
\hline $11 / 2$ in & $0.00 \%$ & 100 & 0 & 0 & 0 & 0.00 & $0.0 \%$ & & \\
\hline 1 in & $0.00 \%$ & 100 & 0 & 0 & 0 & 0.00 & $0.0 \%$ & & \\
\hline $3 / 4$ in & $3.21 \%$ & 100 & 0 & 0 & 0 & 0.00 & $0.0 \%$ & & \\
\hline $1 / 2$ in & $53.44 \%$ & 107 & 0 & 0 & 0 & 0.00 & $0.0 \%$ & & \\
\hline $3 / 8$ in & $27.89 \%$ & 120 & 0 & 0 & 0 & 0.00 & $0.0 \%$ & & \\
\hline No. 4 & $12.30 \%$ & 102 & 0 & 0 & 0 & 0.00 & $0.0 \%$ & & \\
\hline Total & $96.85 \%$ & & & & & & $0.0 \%$ & & 0.0 \\
\hline
\end{tabular}




\section{Georgetown Sand Fine Aggregate}

\begin{tabular}{|c|c|c|c|c|c|c|c|c|c|}
\hline \multicolumn{10}{|c|}{ Summary of Aggregate Tests Report } \\
\hline \multicolumn{3}{|c|}{ Material Description: } & \multicolumn{2}{|l|}{ Fine Aggregate } & \multirow{2}{*}{\multicolumn{2}{|c|}{\begin{tabular}{r|} 
Performing \\
Organizaion:
\end{tabular}}} & \multirow{2}{*}{\multicolumn{3}{|c|}{$\begin{array}{l}\text { Geotechnical and Structures Lab } \\
\text { Concrete and Materials Branch }\end{array}$}} \\
\hline & & Source: & \multicolumn{2}{|c|}{ Georgetown Sand \& Gravel } & & & & & \\
\hline \multirow{2}{*}{\multicolumn{3}{|c|}{$\begin{array}{r}\text { Location: } \\
\text { CMB Log in \#: }\end{array}$}} & \multicolumn{2}{|c|}{ Georgetown, PA } & \multicolumn{2}{|c|}{ Tested by: } & \multicolumn{3}{|l|}{ R. Hardy } \\
\hline & & & 150069 & & \multirow{2}{*}{\multicolumn{2}{|c|}{\begin{tabular}{|l|} 
Reviewed by: \\
ower Mon Area Office
\end{tabular}}} & \multicolumn{3}{|c|}{ J. Burroughs/M. Ramsey } \\
\hline \multicolumn{3}{|c|}{ Sponsoring Organization: } & \multicolumn{5}{|c|}{ USACE Pittsburgh District, Lower Mon Area Office } & & \\
\hline \multicolumn{9}{|c|}{\begin{tabular}{r|l} 
Project: & Charleroi Lock and Dam Monongahela River Reconstruction Project \\
\end{tabular}} & \\
\hline \multicolumn{10}{|c|}{ ASTM C 136 Sieve Analysis: } \\
\hline \multirow{2}{*}{ Sieve Size } & Run & & Cumulati & ve Percent & Run 2 & & Cumula & e Percent & Avg $\%$ \\
\hline & Mass Ret, g & \% Ret. & Ret. & Pass & Mass Ret, g & \% Ret. & Ret. & Pass & Passing \\
\hline $3 / 8$ in. & 0.00 & $0.00 \%$ & $0.00 \%$ & $100.00 \%$ & 0.00 & $0.00 \%$ & $0.00 \%$ & $100.00 \%$ & $100 \%$ \\
\hline No. 4 & 10.60 & $2.19 \%$ & $2.19 \%$ & $97.81 \%$ & 9.30 & $2.02 \%$ & $2.02 \%$ & $97.98 \%$ & $98 \%$ \\
\hline No. 8 & 53.90 & $11.11 \%$ & $13.30 \%$ & $86.70 \%$ & 55.00 & $11.94 \%$ & $13.96 \%$ & $86.04 \%$ & $86 \%$ \\
\hline No. 16 & 63.00 & $12.99 \%$ & $26.29 \%$ & $73.71 \%$ & 56.20 & $12.20 \%$ & $26.17 \%$ & $73.83 \%$ & $74 \%$ \\
\hline No. 30 & 89.80 & $18.52 \%$ & $44.80 \%$ & $55.20 \%$ & 85.90 & $18.65 \%$ & $44.82 \%$ & $55.18 \%$ & $55 \%$ \\
\hline No. 40 & 106.80 & $22.02 \%$ & $66.82 \%$ & $33.18 \%$ & 102.70 & $22.30 \%$ & $67.12 \%$ & $32.88 \%$ & $33 \%$ \\
\hline No. 50 & 95.30 & $19.65 \%$ & $86.47 \%$ & $13.53 \%$ & 88.60 & $19.24 \%$ & $86.36 \%$ & $13.64 \%$ & $14 \%$ \\
\hline No. 100 & 54.00 & $11.13 \%$ & $97.61 \%$ & $2.39 \%$ & 51.30 & $11.14 \%$ & $97.50 \%$ & $2.50 \%$ & $2 \%$ \\
\hline No. 200 & 10.40 & $2.14 \%$ & $99.75 \%$ & $0.25 \%$ & 9.90 & $2.15 \%$ & $99.65 \%$ & $0.35 \%$ & $0 \%$ \\
\hline Pan & 1.20 & $0.25 \%$ & $100.00 \%$ & & 1.60 & $0.35 \%$ & $100.00 \%$ & & \\
\hline Total & 485.00 & $100.00 \%$ & & & 460.50 & & & & \\
\hline & eness Modulus & & 2.707 & & & & 2.708 & & 2.71 \\
\hline & & & ASTM & C 117 Minus 7 & 75 um (No. 200) & & & & \\
\hline OD Mass, $\mathrm{g}$ & 489.90 & Mass Aft, $\mathrm{g}$ & 485 & Mass Loss, $\mathrm{g}$ & 4.90 & $\%$ Loss: & $1.00 \%$ & & Avg Loss \\
\hline OD Mass, $\mathrm{g}$ & 464.40 & Mass Aft, $\mathrm{g}$ & 460.7 & Mass Loss, $\mathrm{g}$ & 3.70 & $\%$ Loss: & $0.80 \%$ & & $0.9 \%$ \\
\hline & & & ASTM C 127 & Bulk Specific & Gravity \& Absor & rption: & & & \\
\hline & & & & & & & Run 1 & Run 2 & Avg \\
\hline & & & SSD Mass, g & & & & 503.80 & 507.90 & \\
\hline & & Mass & Flask+Water, & & & & 1261.80 & 1474.60 & \\
\hline & & Mass Flas & $\mathrm{sk}+$ Water+Mat & erial, $\mathrm{g}$ & & & 1573.50 & 1788.30 & \\
\hline & & Mass D & Displaced Wate & $\mathrm{g}, \mathrm{g}$ & & & 192.10 & 194.20 & \\
\hline & & & Vater Temp C & & & & 22.7 & 22.7 & \\
\hline & Rela & ative Density & (Bulk Specific & Gravity)(SSD) & & & 2.623 & 2.615 & 2.62 \\
\hline & & & SSD Mass, $\mathrm{g}$ & & & & 503.80 & 507.90 & \\
\hline & & Ove & en Dry Mass, $\mathrm{g}$ & & & & 496.90 & 500.90 & \\
\hline & & & oisture Loss, $\mathrm{g}$ & & & & $690.00 \%$ & $700.00 \%$ & \\
\hline & & & Absorption & & & & $1.39 \%$ & $1.40 \%$ & $1.39 \%$ \\
\hline & & ASTM & C 40 Organic & Impurity Color & Plate Number: & & & & 2 \\
\hline & & & ASTM C $88 \mathrm{Ma}$ & gnesium Sulfat & e Soundness (5 & 5 cycles): & & & \\
\hline & Gradation > 5\% & OD Mass, $\mathrm{g}$ & Mass Aft, $\mathrm{g}$ & $\%$ Loss & Wt'ed \% Loss & & & & \\
\hline No. 4 & $2 \%$ & 0.00 & 0.00 & & & & & & \\
\hline No. 8 & $12 \%$ & 100.40 & 88.40 & $12.0 \%$ & $1.38 \%$ & & & & \\
\hline No. 16 & $13 \%$ & 100.40 & 88.70 & $11.7 \%$ & $1.47 \%$ & & & & \\
\hline No. 30 & $19 \%$ & 100.60 & 87.80 & $12.7 \%$ & $2.36 \%$ & & & & \\
\hline No. 50 & $19 \%$ & 100.30 & 89.50 & $10.8 \%$ & $2.09 \%$ & & & & \\
\hline No. 100 & $11 \%$ & 100.00 & 92.10 & $7.9 \%$ & $0.88 \%$ & & & & \\
\hline Total & & & & & $8.18 \%$ & & & & $8.2 \%$ \\
\hline & & AST & TM C 123 Light & Weight Particle & es and Pieces in & in Aggrega & ate & & \\
\hline Zinc Bromide & .40 sp.gr. & & & & & & & & \\
\hline OD Mass, $\mathrm{g}$ & 477.1 & Mass Aft, $\mathrm{g}$ & 471.20 & & & & & \% Loss: & $1.2 \%$ \\
\hline Zinc Chloride & 00 sp.gr. & & & & & & & & \\
\hline OD Mass, $\mathrm{g}$ & 471.2 & Mass Aft, $\mathrm{g}$ & 465.40 & & & & & \% Loss: & $1.2 \%$ \\
\hline & & & ASTM C 1 & 42 Clay Lumps & \& Friable Part & les: & & & \\
\hline OD Mass, $\mathrm{g}$ & 270.1 & Mass Aft, $\mathrm{g}$ & 269.80 & Loss, $\mathrm{g}$ & 0.30 & & & Loss, \% & $0.11 \%$ \\
\hline
\end{tabular}




\section{Shelly Sand Fine Aggregate}

\begin{tabular}{|c|c|c|c|c|c|c|c|c|c|}
\hline \multicolumn{10}{|c|}{ Summary of Aggregate Tests Report } \\
\hline \multicolumn{3}{|c|}{ Material Description: } & \multicolumn{2}{|l|}{ Fine Aggregate } & \multirow{2}{*}{\multicolumn{2}{|c|}{ Performing Organizaion: }} & \multirow{2}{*}{\multicolumn{3}{|c|}{$\begin{array}{l}\text { Geotechnical and Structures Lab } \\
\text { Concrete and Materials Branch }\end{array}$}} \\
\hline & & Source: & \multicolumn{2}{|l|}{ Shelly Materials } & & & & & \\
\hline & & Location: & \multicolumn{2}{|l|}{ Thornville, $\mathrm{OH}$} & \multicolumn{2}{|c|}{ Tested by: } & \multicolumn{3}{|c|}{ R. Hardy } \\
\hline & & CMB Log in \#: & 160004 & & \multicolumn{2}{|c|}{ Reviewed by: } & \multicolumn{3}{|c|}{ J. Burroughs/M. Ramsey } \\
\hline \multicolumn{3}{|c|}{ Sponsoring Organization: } & \multicolumn{7}{|c|}{ USACE Pittsburgh District, Lower Mon Area Office } \\
\hline \multirow{2}{*}{\multicolumn{3}{|c|}{ Project: }} & \\
\hline & & & \multicolumn{7}{|c|}{$\begin{array}{l}\text { Charleroi Lock and Dam Monongahela River Reconstruction Project } \\
\text { ASTM C } 136 \text { Sieve Analysis: }\end{array}$} \\
\hline \multirow{2}{*}{ Sieve Size } & $\mathrm{Ru}$ & In 1 & Cumulative & e Percent & Run 2 & & Cumule & ve Percent & Avg \% \\
\hline & Mass Ret, g & $\%$ Ret. & Ret. & Pass & Mass Ret, g & $\%$ Ret. & Ret. & Pass & Passing \\
\hline $3 / 8$ in. & 0.00 & $0.00 \%$ & $0.00 \%$ & $100.00 \%$ & 0.00 & $0.00 \%$ & $0.00 \%$ & $100.00 \%$ & $100 \%$ \\
\hline No. 4 & 5.90 & $1.09 \%$ & $1.09 \%$ & $98.91 \%$ & 6.10 & $1.11 \%$ & $1.11 \%$ & $98.89 \%$ & $99 \%$ \\
\hline No. 8 & 55.60 & $10.27 \%$ & $11.36 \%$ & $88.64 \%$ & 57.90 & $10.56 \%$ & $11.67 \%$ & $88.33 \%$ & $88 \%$ \\
\hline No. 16 & 60.90 & $11.25 \%$ & $22.61 \%$ & $77.39 \%$ & 59.10 & $10.78 \%$ & $22.45 \%$ & $77.55 \%$ & $77 \%$ \\
\hline No. 30 & 112.50 & $20.78 \%$ & $43.39 \%$ & $56.61 \%$ & 112.60 & $20.53 \%$ & $42.98 \%$ & $57.02 \%$ & $57 \%$ \\
\hline No. 40 & 146.50 & $27.06 \%$ & $70.45 \%$ & $29.55 \%$ & 150.40 & $27.43 \%$ & $70.40 \%$ & $29.60 \%$ & $30 \%$ \\
\hline No. 50 & 98.60 & $18.21 \%$ & $88.66 \%$ & $11.34 \%$ & 98.30 & $17.92 \%$ & $88.33 \%$ & $11.67 \%$ & $12 \%$ \\
\hline No. 100 & 52.10 & $9.62 \%$ & $98.28 \%$ & $1.72 \%$ & 53.70 & $9.79 \%$ & $98.12 \%$ & $1.88 \%$ & $2 \%$ \\
\hline No. 200 & 8.50 & $1.57 \%$ & $99.85 \%$ & $0.15 \%$ & 8.80 & $1.60 \%$ & $99.73 \%$ & $0.27 \%$ & $0 \%$ \\
\hline Pan & 0.80 & $0.15 \%$ & $100.00 \%$ & & 1.50 & $0.27 \%$ & $100.00 \%$ & & \\
\hline Total & 541.40 & $100.00 \%$ & & & 548.40 & $100.00 \%$ & & & \\
\hline & neness Modulu & & 2.654 & & & & 2.647 & & 2.65 \\
\hline & & & ASTM C & 117 Minus 75 & 5um (No. 200) & & & & \\
\hline OD Mass, g & 544.40 & Mass Aft, g & 541.4 & Mass Loss, $\mathrm{g}$ & 3.00 & \% Loss: & $0.55 \%$ & & Avg Loss \\
\hline OD Mass, $\mathrm{g}$ & 551.90 & Mass Aft, $\mathrm{g}$ & 548.4 & Mass Loss, $\mathrm{g}$ & 3.50 & \% Loss: & $0.63 \%$ & & $0.6 \%$ \\
\hline & & & ASTM C 127: & Bulk Specific G & Gravity \& Absor & ption: & & & \\
\hline & & & & & & & Run 1 & Run 2 & Avg \\
\hline & & & SD Mass, $\mathrm{g}$ & & & & 508.60 & 505.10 & \\
\hline & & Mass & Flask+Water, g & & & & 1263.50 & 1479.20 & \\
\hline & & Mass Flask & $\mathrm{K}+\mathrm{W}$ ater+Materi & ial, $\mathrm{g}$ & & & 1576.30 & 1790.10 & \\
\hline & & Mass Di & splaced Water, & & & & 195.80 & 194.20 & \\
\hline & & $\mathrm{Wa}$ & ater Temp C & & & & 21.8 & 21.8 & \\
\hline & & lative Density (E & Bulk Specific $\mathrm{Gr}$ & ravity)(SSD) & & & 2.598 & 2.601 & 2.60 \\
\hline & & Oven & Dry Mass, g & & & & 499.90 & 496.60 & \\
\hline & & Mois & sture Loss, g & & & & 8.70 & 8.50 & \\
\hline & & & Absorption & & & & $1.74 \%$ & $1.71 \%$ & $1.7 \%$ \\
\hline & & ASTM & C 40 Organic Im & npurity Color PI & late Number: & & & & 2 \\
\hline ASTM C $88 \mathrm{Ma}$ & gnesium Sulfat & te Soundness (5 & cycles): & New Solutio & on 1.299 sp.gr. & & & & \\
\hline Gradatic & $n>5 \%$ & OD Mass, $\mathrm{g}$ & Mass Aft, $\mathrm{g}$ & $\%$ Loss & Wt'ed \% Loss & & & & \\
\hline No. 4 & $1 \%$ & & & $11.1 \%$ & $0.12 \%$ & & & & \\
\hline No. 8 & $10 \%$ & 100.00 & 88.90 & $11.1 \%$ & $1.16 \%$ & & & & \\
\hline \begin{tabular}{|l|} 
No. 16 \\
\end{tabular} & $11 \%$ & 100.00 & 86.80 & $13.2 \%$ & $1.45 \%$ & & & & \\
\hline \begin{tabular}{|l|} 
No. 30 \\
\end{tabular} & $21 \%$ & 100.10 & 81.90 & $18.2 \%$ & $3.76 \%$ & & & & \\
\hline Nos. $40 \& 50$ & $45 \%$ & 100.10 & 90.70 & $9.4 \%$ & $4.25 \%$ & & & & \\
\hline No. 100 & $10 \%$ & & & & & & & & \\
\hline Minus No. 100 & $2 \%$ & & & & & & & & \\
\hline Total & $100 \%$ & & & & $10.62 \%$ & & & & $10.6 \%$ \\
\hline & & ASTN & M C 123 Light $W$ & Veight Particles & $\mathrm{s}$ and Pieces in & Agg & & & \\
\hline Zinc Bromide 2 & 40 sp.gr. & & & & & & & & \\
\hline OD Mass, g & 531.5 & Mass Aft, $\mathrm{g}$ & 525.60 & & & & & $\%$ Loss: & $1.11 \%$ \\
\hline Zinc Chloride 2 & 00 sp.gr. & & & & & & & & \\
\hline OD Mass, $\mathrm{g}$ & 535.3 & Mass Aft, $\mathrm{g}$ & 531.40 & & & & & $\%$ Loss: & $0.73 \%$ \\
\hline & & & ASTM C 142 & Clay Lumps \& & Friable Particl & es: & & & \\
\hline OD Mass, $\mathrm{g}$ & 156.2 & Mass Aft, $\mathrm{g}$ & 155.80 & Loss, $\mathrm{g}$ & 0.40 & & & Loss, $\%$ & $0.26 \%$ \\
\hline
\end{tabular}




\section{Limestone Powder}

\begin{tabular}{|c|c|c|c|c|c|c|c|c|c|}
\hline \multirow{3}{*}{ 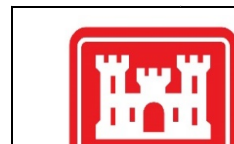 } & $\bar{m}$ & \multicolumn{3}{|c|}{$\begin{array}{l}\text { Report on Test } \\
\text { Specifications: }\end{array}$} & \multicolumn{5}{|c|}{$\begin{array}{l}\text { ASTM C1271 and C1301 for chemical properties and ASTM } \\
\text { D546 and D4318 for physical properties of limestone powder. }\end{array}$} \\
\hline & 1 & \multicolumn{5}{|c|}{ Performing Orgnaization: } & \multicolumn{3}{|c|}{ Sponsoring Orgnaization: } \\
\hline & & \multicolumn{5}{|c|}{ U.S Army Engineer Research and Development Center } & \multicolumn{3}{|c|}{ U.S. Army Corps of Engineers } \\
\hline \multirow{3}{*}{\multicolumn{2}{|c|}{$\begin{array}{l}\text { US Army Corps of Engineers } \\
\text { BUILDING STRONG. }\end{array}$}} & \multicolumn{5}{|c|}{ Geotechnical and Structures Laboratory (CEERD-GMC) } & \multicolumn{3}{|c|}{ Pittsburgh District, Lower Mon Area Office } \\
\hline & & \multicolumn{5}{|c|}{3909 Halls Ferry Road } & \multicolumn{3}{|c|}{1811 Schoonmaker Ave., } \\
\hline & & \multicolumn{3}{|c|}{ Vicksburg, MS 39180-6199 } & & & \multicolumn{3}{|c|}{ Monesson, PA 15062} \\
\hline \multicolumn{5}{|c|}{ Material Description: Limestone Powder } & & & & & \\
\hline \multicolumn{2}{|r|}{ Manufacturer: } & \multicolumn{3}{|c|}{ Graymont Limestone } & & & & & \\
\hline \multicolumn{2}{|r|}{ Location: } & \multicolumn{3}{|c|}{ Pleasant Gap, PA } & & & & & \\
\hline \multicolumn{2}{|r|}{ CMB Serial \#: } & \multicolumn{3}{|l|}{150067} & & & & & \\
\hline \multirow{2}{*}{\multicolumn{5}{|c|}{$\begin{array}{l}\text { Project: Charleroi Lock and Dam Monong } \\
\text { Chemical Analysis }\end{array}$}} & ahela River $\operatorname{Re}$ & constructior & in Project & & \\
\hline & & & & & \multicolumn{5}{|c|}{ Test Results } \\
\hline \multicolumn{5}{|c|}{$\mathrm{SiO}_{2}, \%$} & \multicolumn{5}{|c|}{0.95} \\
\hline & & $\mathrm{O}_{3}, \%$ & & & & & 0.38 & & \\
\hline & & $\mathrm{O}_{3}, \%$ & & & & & 0.15 & & \\
\hline & & $\mathrm{O}, \%$ & & & & & 54.18 & & \\
\hline & & $20, \%$ & & & & & 0.04 & & \\
\hline & & $20, \%$ & & & & & 0.09 & & \\
\hline & & $\mathrm{gO}, \%$ & & & & & 0.71 & & \\
\hline & & $2, \%$ & & & & & 0.17 & & \\
\hline & Loss on ign & ition $\left(950^{\circ} \mathrm{C}\right)$ & $\%$ & & & & 43.29 & & \\
\hline & Calculater & Compound & & & & & & & \\
\hline & Ca as & $\mathrm{CaCO}_{3}, \%$ & & & & & 96.69 & & \\
\hline & $\mathrm{Mg}$ as & $\mathrm{MgCO}_{3}, \%$ & & & & & 1.49 & & \\
\hline & Calculated $\mathrm{Ce}$ & arbonates as & $\mathrm{CO}_{2}$ & & & & 43.29 & & \\
\hline & L.O.I. / C & $\mathrm{O}_{2}$ Balance & & & & & 1 & & \\
\hline Calc & culated Compo & unds- $\mathrm{Mg}$ as & Dolomite & & & & & & \\
\hline & $\mathrm{Mg}$ as $\mathrm{Ca}$ & $\mathrm{Mg}\left(\mathrm{CO}_{3) 2}, \mathrm{o}\right.$ & & & & & 3.26 & & \\
\hline & Residual Ce & as $\mathrm{CaCO}_{3}$, & & & & & 94.92 & & \\
\hline & & STM D 546 & Sieve Analy & ysis of Mine & eral Filler for $\mathrm{Bi}$ & ituminous $\mathrm{P}$ & aving Mixtur & & \\
\hline & Run & & Cumulativ & ve Percent & Run & & Cumulativ & Percent & \\
\hline Sieve Size & $\begin{array}{c}\text { Mass } \\
\text { Retained, } g\end{array}$ & \begin{tabular}{c|c}
$\%$ \\
Retained
\end{tabular} & \begin{tabular}{c|c}
$\%$ \\
Retained
\end{tabular} & $\%$ Passing & \begin{tabular}{c|} 
Mass \\
Retained, $g$
\end{tabular} & \begin{tabular}{c|}
$\%$ \\
Retained
\end{tabular} & $\begin{array}{c}\% \\
\text { Retained }\end{array}$ & \begin{tabular}{c|c|}
$\%$ \\
Passing
\end{tabular} & Avg. \% Passing \\
\hline No. 16 & 0.00 & $0.00 \%$ & $0.00 \%$ & $100.00 \%$ & 0.00 & $0.00 \%$ & $0.00 \%$ & $100.00 \%$ & $100.00 \%$ \\
\hline No. 30 & 0.52 & $0.51 \%$ & $0.51 \%$ & $99.49 \%$ & 0.60 & $0.53 \%$ & $0.53 \%$ & $99.47 \%$ & $99.48 \%$ \\
\hline No. 50 & 0.50 & $0.49 \%$ & $1.00 \%$ & $99.00 \%$ & 0.58 & $0.51 \%$ & $1.04 \%$ & $98.96 \%$ & $98.98 \%$ \\
\hline No. 100 & 1.93 & $1.89 \%$ & $2.89 \%$ & $97.11 \%$ & 2.08 & $1.83 \%$ & $2.87 \%$ & $97.13 \%$ & $97.12 \%$ \\
\hline No. 200 & 22.00 & $21.56 \%$ & $24.45 \%$ & $75.55 \%$ & 24.16 & $21.25 \%$ & $24.12 \%$ & $75.88 \%$ & $75.72 \%$ \\
\hline Minus No.200 & 77.09 & $75.55 \%$ & $100.00 \%$ & & 86.28 & $75.88 \%$ & $100.00 \%$ & & \\
\hline Original Sample & 102.04 & $100.00 \%$ & & & 113.70 & $100.00 \%$ & & & \\
\hline
\end{tabular}




\section{Appendix B: Freezing and Thawing Reports}

\section{Hanson Coarse Aggregate}

\begin{tabular}{|c|c|c|c|c|c|c|c|c|c|c|c|c|c|c|c|}
\hline \multicolumn{16}{|c|}{ Res istance of Concrete to Rapid Freezing and Thawing, ASTM C666 } \\
\hline \multicolumn{5}{|c|}{ Project: } & \multirow{3}{*}{\multicolumn{11}{|c|}{$\begin{array}{c}\text { Charler oi L\&D, Monogahela River Project } \\
\text { Pittsburgh District } \\
\text { Hanson Test Coarse Aggregate }\end{array}$}} \\
\hline \multicolumn{5}{|c|}{ Customer: } & & & & & & & & & & & \\
\hline \multicolumn{5}{|c|}{ Mixture ID: } & & & & & & & & & & & \\
\hline \multicolumn{5}{|c|}{ Materials } & \multicolumn{7}{|c|}{ Testing Specifics } & & & & \\
\hline Fine Aggregate & \multicolumn{4}{|c|}{ Arkadelphia Control Sand } & \multicolumn{5}{|c|}{ Maximum Cycles } & \multicolumn{2}{|c|}{300} & & & & \\
\hline Coarse Aggregate & \multicolumn{4}{|c|}{ Hanson Test Coarse Aggregate } & \multicolumn{5}{|c|}{ Min. Dynamic Modulus at Failure (\%) } & \multicolumn{2}{|c|}{50} & & & & \\
\hline Cement & \multicolumn{4}{|c|}{ Armstrong Type II (MH) } & \multicolumn{5}{|c|}{ Slump (in.) ASTM C143 } & \multicolumn{2}{|c|}{3} & & & & \\
\hline Admixture & \multicolumn{4}{|c|}{ Eucon AEA 92} & \multicolumn{5}{|c|}{ Air Content (\%) ASTM C231 } & \multicolumn{2}{|c|}{6} & & & & \\
\hline \multicolumn{16}{|c|}{ Meas urements } \\
\hline Added & 0 & 4 & 11 & 24 & 12 & 27 & 33 & 24 & 24 & 11 & 22 & 36 & 24 & 23 & 36 \\
\hline Cummulative & 0 & 4 & 15 & 39 & 51 & 78 & 111 & 135 & 159 & 170 & 192 & 228 & 252 & 275 & 311 \\
\hline \multicolumn{16}{|c|}{ Specimen 1} \\
\hline Measured Freqency & 1844 & 1804 & 1795 & 1791 & 1781 & 1774 & 1745 & 1726 & 1704 & 1725 & 1679 & 1644 & 1631 & 1589 & 1546 \\
\hline Specimen Weight (lb) & 21.51 & 21.53 & 21.53 & 21.53 & 21.52 & 21.5 & 21.47 & 21.44 & 21.39 & 21.37 & 21.33 & 21.26 & 212 & 21.15 & 21.05 \\
\hline Rel Dyn Elastic Modulus & - & 96 & 95 & 94 & 93 & 93 & 90 & 88 & 85 & 88 & 83 & 79 & 78 & 74 & 70 \\
\hline Weight loss (lb) & - & 0.02 & 0.02 & 0.02 & 0.01 & -0.01 & -0.04 & -0.07 & -0.12 & -0.14 & -0.18 & -0.25 & -0.31 & -0.36 & -0.46 \\
\hline Mass Loss (\%) & & 0.09 & 0.09 & 0.09 & 0.05 & 0.05 & 0.19 & 0.33 & 0.56 & 0.65 & 0.84 & 1.16 & 1.44 & 1.67 & 2.14 \\
\hline Durability Factor & - & 1 & 5 & 12 & 16 & 24 & 33 & 39 & 45 & 50 & 53 & 60 & 66 & 68 & 73 \\
\hline & & & & & & & imen 2 & & & & & & & & \\
\hline Measured Freqency & 1831 & 1790 & 1780 & 1776 & 1760 & 1712 & 1674 & 1659 & 1630 & 1670 & 1613 & 1545 & 1507 & 1458 & 1425 \\
\hline Specimen Weight (lb) & 21.29 & 21.31 & 21.32 & 21.32 & 21.31 & 21.3 & 21.22 & 21.17 & 21.12 & 21.09 & 21.01 & 20.94 & 20.88 & 20.82 & 20.74 \\
\hline Rel Dyn Elastic Modulus & - & 96 & 95 & 94 & 92 & 87 & 84 & 82 & 79 & 83 & 78 & 71 & 68 & 63 & 61 \\
\hline Weight loss (lb) & - & 0.02 & 0.03 & 0.03 & 0.02 & 0.01 & -0.07 & -0.12 & -0.17 & -0.2 & -0.28 & -0.35 & -0.41 & -0.47 & -0.55 \\
\hline Mass Loss (\%) & & 0.09 & 0.14 & 0.14 & 0.09 & 0.05 & 0.33 & 0.56 & 0.80 & 0.94 & 1.32 & 1.64 & 1.93 & 2.21 & 2.58 \\
\hline Durability Factor & - & 1 & 5 & 12 & 16 & 23 & 31 & 37 & 42 & 47 & 50 & 54 & 57 & 58 & 63 \\
\hline & & & & & & & imen 3 & & & & & & & & \\
\hline Measured Freqency & 1871 & 1838 & 1829 & 1823 & 1819 & 1820 & 1795 & 1785 & 1775 & 1797 & 1765 & 1739 & 1713 & 1681 & 1599 \\
\hline Spe cimen Weight (lb) & 21.58 & 21.58 & 21.59 & 21.59 & 21.58 & 21.54 & 21.5 & 21.45 & 21.41 & 21.37 & 21.33 & 21.24 & 21.2 & 21.12 & 20.99 \\
\hline Rel Dyn Elastic Modulus & - & 97 & 96 & 95 & 95 & 95 & 92 & 91 & 90 & 92 & 89 & 86 & 84 & 81 & 73 \\
\hline Weight loss (lb) & - & 0 & 0.01 & 0.01 & 0 & -0.04 & -0.08 & -0.13 & -0.17 & -0.21 & -0.25 & -0.34 & -0.38 & -0.46 & -0.59 \\
\hline Mass Loss (\%) & & 0.00 & 0.05 & 0.05 & 0.00 & 0.19 & 0.37 & 0.60 & 0.79 & 0.97 & 1.16 & 1.58 & 1.76 & 2.13 & 2.73 \\
\hline Durability Factor & - & 1 & 5 & 12 & 16 & 25 & 34 & 41 & 48 & 52 & 57 & 66 & 70 & 74 & 76 \\
\hline & & & & & & & erage & & & & & & & & \\
\hline Measured Freqency & 1849 & 1811 & 1801 & 1797 & 1787 & 1769 & 1738 & 1723 & 1703 & 1731 & 1686 & 1643 & 1617 & 1576 & 1523 \\
\hline Specimen Weight (lb) & 21.46 & 21.47 & 21.48 & 21.48 & 21.47 & 21.45 & 21.40 & 21.35 & 21.31 & 21.28 & 21.22 & 21.15 & 21.09 & 21.03 & 20.93 \\
\hline Rel Dyn Elastic Modulus & - & 96 & 95 & 94 & 93 & 92 & 88 & 87 & 85 & 88 & 83 & 79 & 77 & 73 & 68 \\
\hline Weight loss (lb) & - & 0.01 & 0.02 & 0.02 & 0.01 & -0.01 & -0.06 & -0.11 & -0.15 & -0.18 & -0.24 & -0.31 & -0.37 & -0.43 & -0.53 \\
\hline Mass Loss (\%) & & 0.06 & 0.09 & 0.09 & 0.05 & 0.09 & 0.30 & 0.50 & 0.71 & 0.85 & 1.10 & 1.46 & 1.71 & 2.00 & 2.49 \\
\hline Durability Factor & - & 1 & 5 & 12 & 16 & 24 & 33 & 39 & 45 & 50 & 53 & 60 & 64 & 67 & 70 \\
\hline
\end{tabular}




\section{Georgetown Sand Fine Aggregate}

\begin{tabular}{|c|c|c|c|c|c|c|c|c|c|c|c|c|c|c|}
\hline \multicolumn{15}{|c|}{ Resistance of Concrete to Rapid F reezing and Thawing, ASTM C666 } \\
\hline \multicolumn{5}{|c|}{ Project: } & \multicolumn{7}{|c|}{ Charleroi L\&D, Monogahela River Project } & & & \\
\hline \multicolumn{5}{|c|}{ Customer: } & \multicolumn{7}{|c|}{ Pittsburgh District } & & & \\
\hline \multicolumn{5}{|c|}{ Mixture ID: } & \multicolumn{7}{|c|}{ Georgetown Fine Aggregate } & & & \\
\hline \multicolumn{5}{|c|}{ Materials } & \multicolumn{7}{|c|}{ Testing Specifics } & & & \\
\hline Fine Aggre gate & \multicolumn{4}{|c|}{ Georgetown Test Aggregate } & \multicolumn{5}{|c|}{ Maximum Cycles } & \multicolumn{2}{|c|}{300} & & & \\
\hline Coarse Aggregate & \multicolumn{4}{|c|}{ C alera Limestone Control Aggregate } & \multicolumn{5}{|c|}{ Min. Dynamic Modulus at Failure (\%) } & \multicolumn{2}{|c|}{50} & & & \\
\hline Cement & \multicolumn{4}{|c|}{ Armstrong Type II $(\mathrm{MH})$} & \multicolumn{5}{|c|}{ Slump (in.) ASTM C143 } & \multicolumn{2}{|c|}{3} & & & \\
\hline Admixture & & Eucol & EA92 & & & AirCon & t (\%) A & M C231 & & & & & & \\
\hline & & & & & & leasure & & & & & & & & \\
\hline Added & 0 & 20 & 20 & 20 & 20 & 20 & 20 & 20 & 20 & 20 & 20 & 48 & 36 & 16 \\
\hline Cummulative & 0 & 20 & 40 & 60 & 80 & 100 & 120 & 140 & 160 & 180 & 200 & 248 & 284 & 300 \\
\hline & & & & & & Specim & & & & & & & & \\
\hline Measured Freqency & 2019 & 2006 & 1980 & 1973 & 1964 & 1963 & 1960 & 1955 & 1949 & 1938 & 1921 & 1822 & 1750 & 1703 \\
\hline Specimen Weight (b) & 21.41 & 21.4 & 21.4 & 21.4 & 21.4 & 21.41 & 21.4 & 21.41 & 21.4 & 21.35 & 21.29 & 21.18 & 21.18 & 21.15 \\
\hline Rel Dyn Elastic Modulus & - & 99 & 96 & 95 & 95 & 95 & 94 & 94 & 93 & 92 & 91 & 81 & 75 & 71 \\
\hline Weight loss (lb) & - & -0.01 & -0.01 & -0.01 & -0.01 & 0 & -0.01 & 0 & -0.01 & -0.06 & -0.12 & -0.23 & -0.23 & -0.26 \\
\hline Mass Loss (\%) & & 0.05 & 0.05 & 0.05 & 0.05 & 0.00 & 0.05 & 0.00 & 0.05 & 0.28 & 0.56 & 1.07 & 1.07 & 1.21 \\
\hline Durability Factor & - & 7 & 13 & 19 & 25 & 32 & 38 & 44 & 50 & 55 & 60 & 67 & 71 & 71 \\
\hline & & & & & & Specim & & & & & & & & \\
\hline M easured Freqency & 2021 & 2007 & 1979 & 1971 & 1965 & 1963 & 1957 & 1953 & 1943 & 1929 & 1911 & 1810 & 1735 & 1690 \\
\hline Specimen Weight (lb) & 21.56 & 21.55 & 21.55 & 21.54 & 21.55 & 21.55 & 21.54 & 21.54 & 21.52 & 21.49 & 21.42 & 21.35 & 21.3 & 21.29 \\
\hline Rel Dyn Elastic Modulus & - & 99 & 96 & 95 & 95 & 94 & 94 & 93 & 92 & 91 & 89 & 80 & 74 & 70 \\
\hline Weight loss (lb) & - & -0.01 & -0.01 & -0.02 & -0.01 & -0.01 & -0.02 & -0.02 & -0.04 & -0.07 & -0.14 & -0.21 & -0.26 & -0.27 \\
\hline Mass Loss (\%) & & 0.05 & 0.05 & 0.09 & 0.05 & 0.05 & 0.09 & 0.09 & 0.19 & 0.32 & 0.65 & 0.97 & 1.21 & 1.25 \\
\hline Durability Factor & - & 7 & 13 & 19 & 25 & 31 & 38 & 44 & 49 & 55 & 60 & 66 & 70 & 70 \\
\hline & & & & & & Specim & & & & & & & & \\
\hline Measured Freqency & 2018 & 2008 & 1978 & 1970 & 1961 & 1961 & 1957 & 1954 & 1948 & 1931 & 1920 & 1820 & 1745 & 1700 \\
\hline Specimen Weight (lb) & 21.58 & 21.57 & 21.57 & 21.57 & 21.57 & 21.58 & 21.57 & 21.57 & 21.56 & 21.51 & 21.44 & 21.42 & 21.38 & 21.3 \\
\hline Rel Dyn Elastic M odulus & - & 99 & 96 & 95 & 94 & 94 & 94 & 94 & 93 & 92 & 91 & 81 & 75 & 71 \\
\hline Weight loss (lb) & - & -0.01 & -0.01 & -0.01 & -0.01 & 0 & -0.01 & -0.01 & -0.02 & -0.07 & -0.14 & -0.16 & -0.2 & -0.28 \\
\hline Mass Loss (\%) & & 0.05 & 0.05 & 0.05 & 0.05 & 0.00 & 0.05 & 0.05 & 0.09 & 0.32 & 0.65 & 0.74 & 0.93 & 1.30 \\
\hline Durability Factor & - & 7 & 13 & 19 & 25 & 31 & 38 & 44 & 50 & 55 & 60 & 67 & 71 & 71 \\
\hline & & & & & & Spedim & & & & & & & & \\
\hline M easured Freqency & 1790 & 1722 & 1704 & 1678 & 1662 & 1660 & 1649 & 1639 & 1626 & 1630 & 1627 & 1510 & 1450 & 1430 \\
\hline Specimen Weight (lb) & 19.86 & 19.97 & 19.98 & 19.98 & 19.92 & 19.88 & 19.85 & 19.77 & 19.7 & 19.62 & 19.59 & 19.58 & 19.55 & 19.5 \\
\hline Rel Dyn Elastic Modulus & - & 93 & 91 & 88 & 86 & 86 & 85 & 84 & 83 & 83 & 83 & 71 & 66 & 64 \\
\hline Weight loss (lb) & - & 0.11 & 0.12 & 0.12 & 0.06 & 0.02 & -0.01 & -0.09 & -0.16 & -0.24 & -0.27 & -0.28 & -0.31 & -0.36 \\
\hline Mass Loss (\%) & & 0.55 & 0.60 & 0.60 & 0.30 & 0.10 & 0.05 & 0.45 & 0.81 & 1.21 & 1.36 & 1.41 & 1.56 & 1.81 \\
\hline Durability Factor & - & 6 & 12 & 18 & 23 & 29 & 34 & 39 & 44 & 50 & 55 & 59 & 62 & 64 \\
\hline & & & & & & Avera & & & & & & & & \\
\hline M easured Freqency & 1962 & 1936 & 1910 & 1898 & 1888 & 1887 & 1881 & 1875 & 1867 & 1857 & 1845 & 1740.5 & 1670 & 1630.75 \\
\hline Specimen Weight (lb) & 21.10 & 21.12 & 21.13 & 21.12 & 21.11 & 21.11 & 21.09 & 21.07 & 21.05 & 20.99 & 20.94 & 20.8825 & 20.8525 & 20.81 \\
\hline Rel Dyn Elastic Modulus & - & 97 & 95 & 93 & 92 & 92 & 92 & 91 & 90 & 89 & 88 & 79 & 72 & 69 \\
\hline Weight loss (lb) & - & 0.02 & 0.02 & 0.02 & 0.01 & 0.00 & -0.01 & -0.03 & -0.06 & -0.11 & -0.17 & -0.22 & -0.25 & -0.2925 \\
\hline Mass Loss (\%) & & 0.17 & 0.19 & 0.20 & 0.11 & 0.04 & 0.06 & 0.15 & 0.28 & 0.53 & 0.80 & 1.05 & 1.19 & 1.39 \\
\hline Durability Factor & - & 6 & 13 & 19 & 25 & 31 & 37 & 43 & 48 & 54 & 59 & 65 & 68 & 69 \\
\hline
\end{tabular}


Shelly Sand Fine Aggregate

\begin{tabular}{|c|c|c|c|c|c|c|c|c|c|c|c|c|c|c|}
\hline \multicolumn{15}{|c|}{ Resistance of Conc rete to Rapid Freezing and Thawing, ASTM C666 } \\
\hline \multicolumn{5}{|c|}{ Project: } & \multicolumn{10}{|c|}{ Charleroi L\&D, Monogahela River Project } \\
\hline \multicolumn{5}{|c|}{ Customer: } & \multicolumn{10}{|c|}{ Pittsburgh District } \\
\hline \multicolumn{5}{|c|}{ Mixture ID: } & \multicolumn{10}{|c|}{ Shelly Sand Fine Aggregate } \\
\hline \multicolumn{5}{|c|}{ Materials } & \multicolumn{7}{|c|}{ Testing Specifics } & & & \\
\hline Fine Aggregate & \multicolumn{4}{|c|}{ Shelly Sand Test Aggre gate } & \multicolumn{5}{|c|}{ Maximum Cycles } & \multicolumn{2}{|c|}{300} & & & \\
\hline Coarse Aggregate & \multicolumn{4}{|c|}{ Calera Limestone Control Aggregate } & \multicolumn{5}{|c|}{ Min. Dynamic Modulus at Failure (\%) } & \multicolumn{2}{|c|}{50} & & & \\
\hline Cement & \multicolumn{4}{|c|}{ Armstrong Type II (MH) } & \multicolumn{5}{|c|}{ Slump (in.) ASTM C143 } & \multicolumn{2}{|c|}{3} & & & \\
\hline Admixture & \multicolumn{4}{|c|}{ Eucon AEA 92} & \multicolumn{5}{|c|}{ Air Content (\%) ASTM C231 } & \multicolumn{2}{|c|}{6} & & & \\
\hline \multicolumn{15}{|c|}{ Measurements } \\
\hline$\overline{\text { Added }}$ & 0 & 10 & 24 & 12 & 27 & 33 & 24 & 24 & 11 & 22 & 36 & 24 & 23 & 32 \\
\hline Cummulative & 0 & 10 & 34 & 46 & 73 & 106 & 130 & 154 & 165 & 187 & 223 & 247 & 270 & 302 \\
\hline & & & & & & Specim & & & & & & & & \\
\hline Measured Freqency & 1875 & 1805 & 1750 & 1740 & 1722 & 1669 & 1642 & 1640 & 1697 & 1598 & 1515 & 1540 & 1500 & 1490 \\
\hline Specimen Weight (lb) & 21.39 & 21.41 & 21.41 & 21.4 & 21.38 & 21.35 & 21.3 & 21.25 & 21.22 & 21.16 & 21.16 & 21.16 & 21.16 & 20.95 \\
\hline Rel Dyn Elastic Modulus & - & 93 & 87 & 86 & 84 & 79 & 77 & 77 & 82 & 73 & 65 & 67 & 64 & 63 \\
\hline Weight loss (lb) & - & 0.02 & 0.02 & 0.01 & -0.01 & -0.04 & -0.09 & -0.14 & -0.17 & -0.23 & -0.23 & -0.23 & -0.23 & -0.44 \\
\hline Mass Loss (\%) & & 0.09 & 0.09 & 0.05 & 0.05 & 0.19 & 0.42 & 0.65 & 0.79 & 1.08 & 1.08 & 1.08 & 1.08 & 2.06 \\
\hline Durability Factor & - & 3 & 10 & 13 & 21 & 28 & 33 & 39 & 45 & 45 & 49 & 56 & 58 & 64 \\
\hline & & & & & & Specim & & & & & & & & \\
\hline Measured Freqency & 1867 & 1807 & 1783 & 1777 & 1741 & 1692 & 1670 & 1661 & 1679 & 1619 & 1507 & 1487 & 1439 & 1439 \\
\hline Specimen Weight (lb) & 21.43 & 21.45 & 21.45 & 21.44 & 21.43 & 21.4 & 21.36 & 21.31 & 21.28 & 21.23 & 21.14 & 21.06 & 20.97 & 20.88 \\
\hline Rel Dyn Elastic Modulus & - & 94 & 91 & 91 & 87 & 82 & 80 & 79 & 81 & 75 & 65 & 63 & 59 & 59 \\
\hline Weight loss (lb) & - & 0.02 & 0.02 & 0.01 & 0 & -0.03 & -0.07 & -0.12 & -0.15 & -0.2 & -0.29 & -0.37 & -0.46 & -0.55 \\
\hline Mass Loss (\%) & & 0.09 & 0.09 & 0.05 & 0.00 & 0.14 & 0.33 & 0.56 & 0.70 & 0.93 & 1.35 & 1.73 & 2.15 & 2.57 \\
\hline Durability Factor & - & 3 & 10 & 14 & 21 & 29 & 35 & 41 & 44 & 47 & 48 & 52 & 53 & 60 \\
\hline & & & & & & Specim & & & & & & & & \\
\hline Measured Freqency & 1847 & 1783 & 1762 & 1757 & 1736 & 1705 & 1675 & 1663 & 1682 & 1642 & 1592 & 1553 & 1447 & 1430 \\
\hline Specimen Weight (Ib) & 21.22 & 2124 & 21.23 & 21.22 & 21.2 & 21.13 & 21.09 & 21.04 & 21.02 & 20.97 & 20.9 & 20.82 & 20.76 & 20.65 \\
\hline Rel Dyn Elastic Modulus & - & 93 & 91 & 90 & 88 & 85 & 82 & 81 & 83 & 79 & 74 & 71 & 61 & 60 \\
\hline Weight loss (lb) & - & 0.02 & 0.01 & 0 & -0.02 & -0.09 & -0.13 & -0.18 & -0.2 & -0.25 & -0.32 & -0.4 & -0.46 & -0.57 \\
\hline Mass Loss (\%) & & 0.09 & 0.05 & 0.00 & 0.09 & 0.42 & 0.61 & 0.85 & 0.94 & 1.18 & 1.51 & 1.89 & 2.17 & 2.69 \\
\hline Durability Factor & - & 3 & 10 & 14 & 21 & 30 & 36 & 42 & 46 & 49 & 55 & 58 & 55 & 60 \\
\hline & & & & & & $\overline{\text { Averac }}$ & & & & & & & & \\
\hline Measured Freqency & 1863 & 1798 & 1765 & 1758 & 1733 & 1689 & 1662 & 1655 & 1686 & 1620 & 1538 & 1527 & 1462 & 1453 \\
\hline Specimen Weight (lb) & 21.35 & 21.37 & 21.36 & 21.35 & 21.34 & 21.29 & 21.25 & 21.20 & 21.17 & 21.12 & 21.07 & 21.01 & 20.96 & 20.83 \\
\hline Rel Dyn Elastic Modulus & - & 93 & 90 & 89 & 87 & 82 & 80 & 79 & 82 & 76 & 68 & 67 & 62 & 61 \\
\hline Weight loss (lb) & - & 0.02 & 0.02 & 0.01 & -0.01 & -0.05 & -0.10 & -0.15 & -0.17 & -0.23 & -0.28 & -0.33 & -0.38 & -0.52 \\
\hline Mass Loss (\%) & & 0.09 & 0.08 & 0.03 & 0.05 & 0.25 & 0.45 & 0.69 & 0.81 & 1.06 & 1.31 & 1.56 & 1.80 & 2.44 \\
\hline Durability Factor & - & 3 & 10 & 14 & 21 & 29 & 35 & 41 & 45 & 47 & 51 & 55 & 55 & 61 \\
\hline
\end{tabular}




\section{Mix 7}

\begin{tabular}{|c|c|c|c|c|c|c|c|c|c|c|c|}
\hline \multicolumn{12}{|c|}{ Resistance of Concrete to Rapid Freezing and Thawing, ASTM C666 } \\
\hline \multicolumn{5}{|c|}{ Project: } & \multicolumn{7}{|c|}{ Charleroi L\&D, Monogahela River Project } \\
\hline \multicolumn{5}{|c|}{ Customer: } & \multicolumn{7}{|c|}{ Fitts burgh District } \\
\hline \multicolumn{5}{|c|}{ Mixture ID: } & \multicolumn{7}{|c|}{ Mix 7} \\
\hline \multicolumn{5}{|c|}{ Materials } & \multicolumn{7}{|c|}{ Testing Specifics } \\
\hline Fine Aggr egate & \multicolumn{4}{|c|}{ Georgetown } & \multicolumn{5}{|c|}{ Maximum Cydes } & \multicolumn{2}{|c|}{300} \\
\hline Coarse Aggregate & \multicolumn{4}{|c|}{ Hars on } & \multicolumn{5}{|c|}{ Min. Dynamic Modulus at Failure (\%) } & \multicolumn{2}{|c|}{50} \\
\hline Cement & \multicolumn{4}{|c|}{ Armstrong Type II (MH) } & \multicolumn{5}{|c|}{ Specimen Cast Date } & \multicolumn{2}{|c|}{$8 / 9 / 2017$} \\
\hline GGBFS, Grade 100 & & Argos & ssroc & & & & cating $\mathrm{Ag}_{\mathrm{g}}$ & noy & & Pitts bur & District \\
\hline Class F Fly Ash & & & & & & Slum & in.) ASTI & C143 & & & \\
\hline Admixtures & & AEA.92 & Ret-75 & & & Air Cor & t (\%) AS & $M C 231$ & & & \\
\hline $\begin{array}{c}\text { Additional Notes on } \\
\text { Materials }\end{array}$ & $\begin{array}{l}\text { After a vi } \\
\text { mois ture } \\
\text { according } \\
\text { frequeno, }\end{array}$ & $\begin{array}{l}\text { I ins pect } \\
\text { no dam } \\
\text { ASTM } 0 \\
\text { dd mass }\end{array}$ & $\begin{array}{l}\text { was ma } \\
\text { e had oc } \\
\text { 6, Proce } \\
\text { the speci }\end{array}$ & $\begin{array}{l}\text { on all th } \\
\text { rred duri } \\
\text { ire A. Th } \\
\text { ens were }\end{array}$ & $\begin{array}{l}\text { pecimer } \\
\text { the tr an } \\
\text { pecimer } \\
\text { corded. }\end{array}$ & $\begin{array}{l}\text { o ens ur } \\
\text { xtation } 0 \\
\text { vere sat }\end{array}$ & $\begin{array}{l}\text { e specin } \\
\text { te besm } \\
\text { ted } 3 \text { dgy }\end{array}$ & $\begin{array}{l}\text { had be } \\
\text { the durs } \\
\text { prior to }\end{array}$ & $\begin{array}{l}\text { protect } \\
\text { y test w } \\
\text { initial fl }\end{array}$ & $\begin{array}{l}\text { sgainst } \\
\text { conduct } \\
\text { lamental }\end{array}$ & $\begin{array}{l}s \text { of } \\
\text { ans vers e }\end{array}$ \\
\hline & & & & Meas & ements & & & & & & \\
\hline Added & 0 & 38 & 24 & 48 & 36 & 24 & 38 & 38 & 24 & 28 & 10 \\
\hline Cummulative & 0 & 38 & 60 & 108 & 144 & 168 & 204 & 240 & 264 & 290 & 300 \\
\hline & & & & Spe & nen 1 & & & & & & \\
\hline Meas ured Freqenoy & 1843 & 1799 & 1793 & 1787 & 1771 & 1785 & 1748 & 1743 & 1727 & 1721 & 1719 \\
\hline Specimen Weight (lb) & 20.17 & 20.22 & 20.19 & 20.18 & 20.16 & 20.15 & 20.11 & 20.08 & 20.02 & 19.98 & 19.96 \\
\hline Rel Dyn Elas tic Modulus & - & 95 & 95 & 94 & $\mathscr{P}$ & 92 & 90 & 89 & 88 & 87 & 87 \\
\hline Weight loss (lb) & - & 0.05 & 0.02 & 0.01 & -0.01 & -0.02 & -0.06 & -0.11 & -0.15 & -0.19 & -0.21 \\
\hline Mass Loss (\%) & & 0.25 & 0.10 & 0.05 & 0.05 & 0.10 & 0.30 & 0.55 & 0.74 & 0.94 & 1.04 \\
\hline Durability Factor & - & 11 & 19 & 34 & 44 & 51 & 61 & 72 & 77 & 84 & 87 \\
\hline & & & & Spe & nen 2 & & & & & & \\
\hline Meas ured Freqenoy & 1858 & 1758 & 1745 & 1734 & 1729 & 1732 & 1709 & 1703 & 1688 & 1679 & 1878 \\
\hline Specimen Weight (lb) & 20.09 & 20.2 & 20.2 & 20.15 & 20.12 & 20.1 & 20.06 & 20.01 & 19.98 & 19.93 & 19.9 \\
\hline Rel Dyn Elas tic Modulus & - & 90 & 88 & 87 & 87 & 87 & 85 & 84 & 83 & 82 & 82 \\
\hline Weight loss (lb) & - & 0.11 & 0.11 & 0.06 & 0.03 & 0.01 & -0.03 & -0.08 & -0.11 & -0.16 & -0.19 \\
\hline Mass Loss (\%) & & 0.55 & 0.55 & 0.30 & 0.15 & 0.05 & 0.15 & 0.40 & 0.55 & 0.80 & 0.95 \\
\hline Durability Factor & - & 11 & 18 & 31 & 4 & 49 & 58 & 67 & 73 & 79 & 82 \\
\hline & & & & Spe & nen 3 & & & & & & \\
\hline Meas ured Freqency & 1807 & 1758 & 1747 & 1741 & 1739 & 1738 & 1721 & 1720 & 1714 & 1708 & 1708 \\
\hline Specimen Weight (Ib) & 19.92 & 19.99 & 19.99 & 19.97 & 19.97 & 19.95 & 19.92 & 19.85 & 19.8 & 19.78 & 19.74 \\
\hline Rel Dyn Elss tic Modulus & - & 95 & 93 & 93 & $\mathfrak{B}$ & 93 & 91 & 91 & 90 & $\mathscr{\theta}$ & 89 \\
\hline Weight loss (lb) & - & 0.07 & 0.07 & 0.05 & 0.05 & 0.03 & 0 & -0.07 & -0.12 & -0.16 & -0.18 \\
\hline Mass Loss (\%) & & 0.35 & 0.35 & 0.25 & 0.25 & 0.15 & 0.00 & 0.35 & 0.60 & 0.80 & 0.90 \\
\hline Durability Factor & - & 11 & 19 & 33 & 44 & 52 & 62 & 72 & 79 & 98 & 89 \\
\hline & & & & Spe & nen 4 & & & & & & \\
\hline Meas ured Freqency & 1790 & 1722 & 1704 & 1678 & 1682 & 1680 & 1649 & 1639 & 1628 & 1630 & 1627 \\
\hline Specimen Weight (lb) & 19.88 & 19.97 & 19.98 & 19.98 & 19.92 & 19.88 & 19.85 & 19.77 & 19.7 & 19.62 & 19.59 \\
\hline Rel Dyn Elas tic Modulus & - & 91 & 89 & 88 & 86 & 84 & 83 & 82 & 81 & 81 & 81 \\
\hline Weight loss (lb) & - & 0.11 & 0.12 & 0.12 & 0.06 & 0.02 & -0.01 & -0.09 & -0.16 & -0.24 & -0.27 \\
\hline Mass Loss (\%) & & 0.55 & 0.60 & 0.60 & 0.30 & 0.10 & 0.05 & 0.45 & 0.81 & 1.21 & 1.38 \\
\hline Durability Factor & - & 11 & 18 & 31 & 41 & 47 & 57 & 68 & 71 & 79 & 81 \\
\hline & & & & & age & & & & & & \\
\hline Meas ured Freqency & 1824 & 1759 & 1747 & 1735 & 1725 & 1724 & 1707 & 1701 & 1689 & 1885 & 1683 \\
\hline Specimen Weight (lb) & 20.01 & 20.10 & 20.09 & 20.07 & 20.04 & 20.02 & 19.99 & 19.92 & 19.88 & 19.82 & 19.80 \\
\hline Rel Dyn Elas tic Modulus & - & 93 & 91 & 90 & 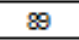 & 89 & 87 & 87 & 85 & 86 & 85 \\
\hline Weight loss (lb) & - & 0.08 & 0.08 & 0.06 & 0.03 & 0.01 & -0.03 & -0.09 & -0.14 & -0.19 & -0.21 \\
\hline Mass Loss (\%) & & 0.43 & 0.40 & 0.30 & 0.19 & 0.10 & 0.12 & 0.44 & 0.67 & 0.94 & 1.06 \\
\hline Durability Factor & - & 11 & 18 & 32 & 43 & 50 & 59 & $\oplus$ & 75 & 82 & 85 \\
\hline
\end{tabular}




\section{Batch Plant and Field Data Sheets for Mix 7}

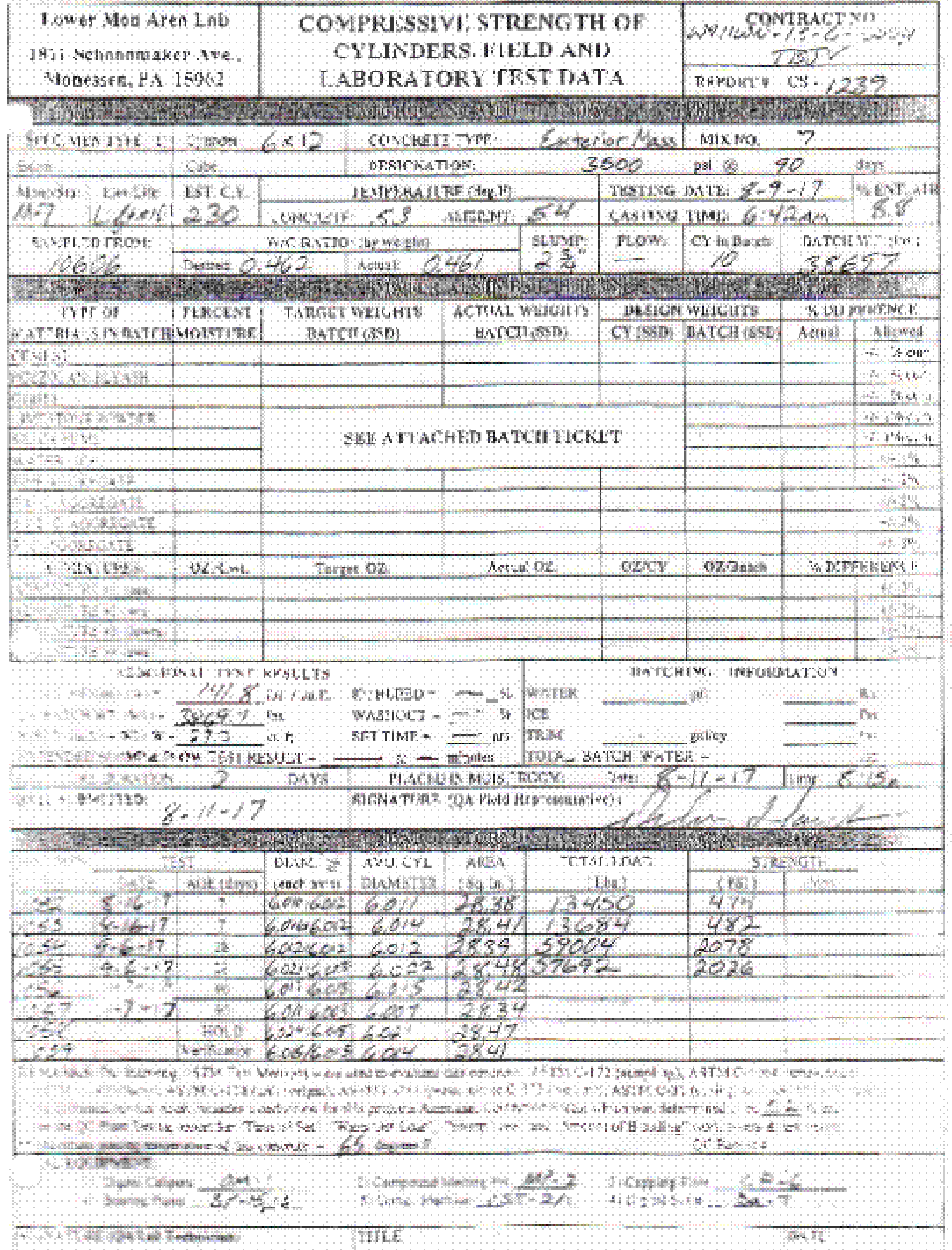


ERDC/GSL TR-20-20

60

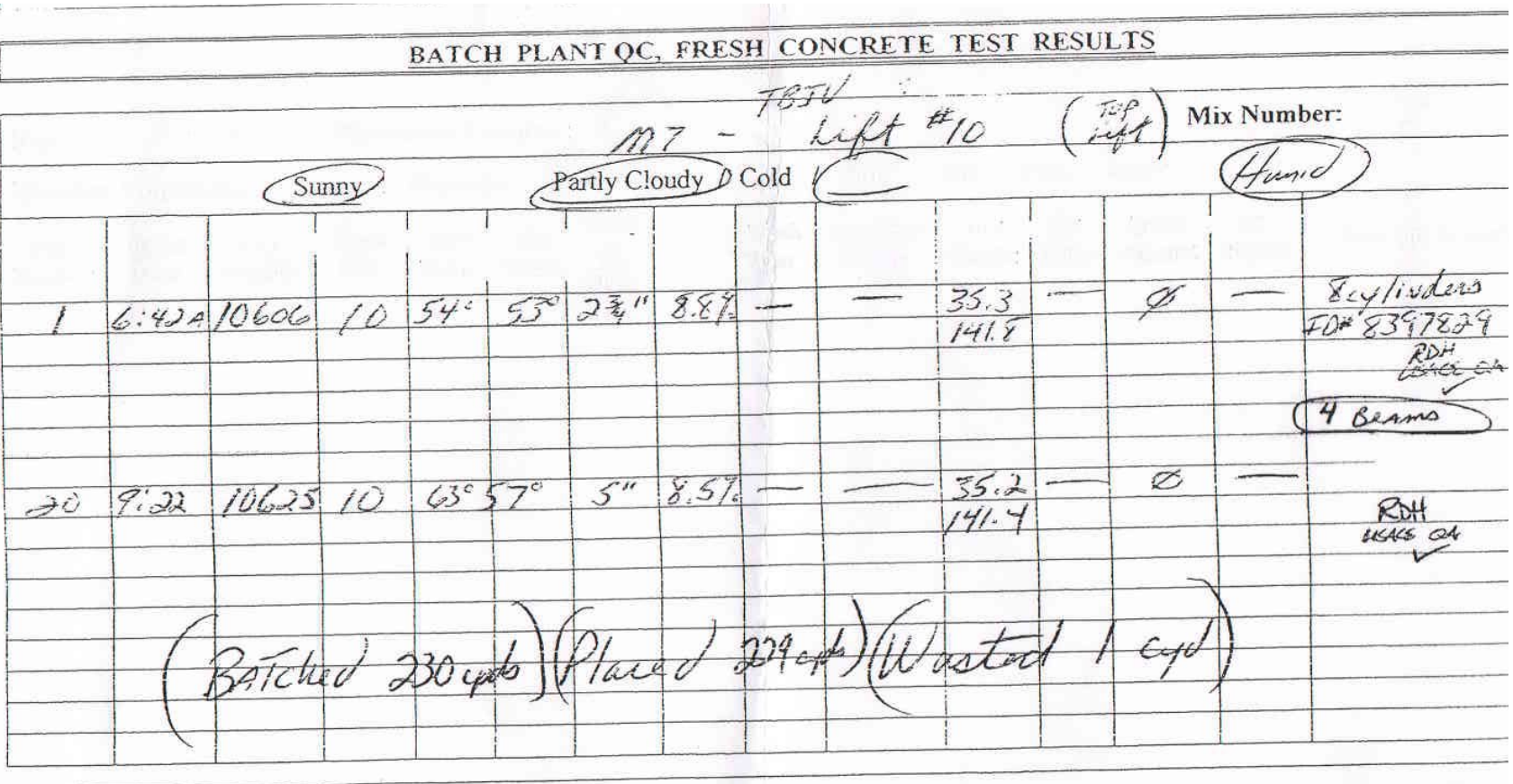

Remarks: (fil metsR conzecrim Facto) River iemp - $72^{\circ}$ dy)
$:$ Date: $\quad 8-7-17$ 


\section{LOWER MON AREA LAB}

USACE-Pittsburgh District

c/o Lower Mon Area Office

1811 Schoonmaker Avenue, Monessen, PA 15062

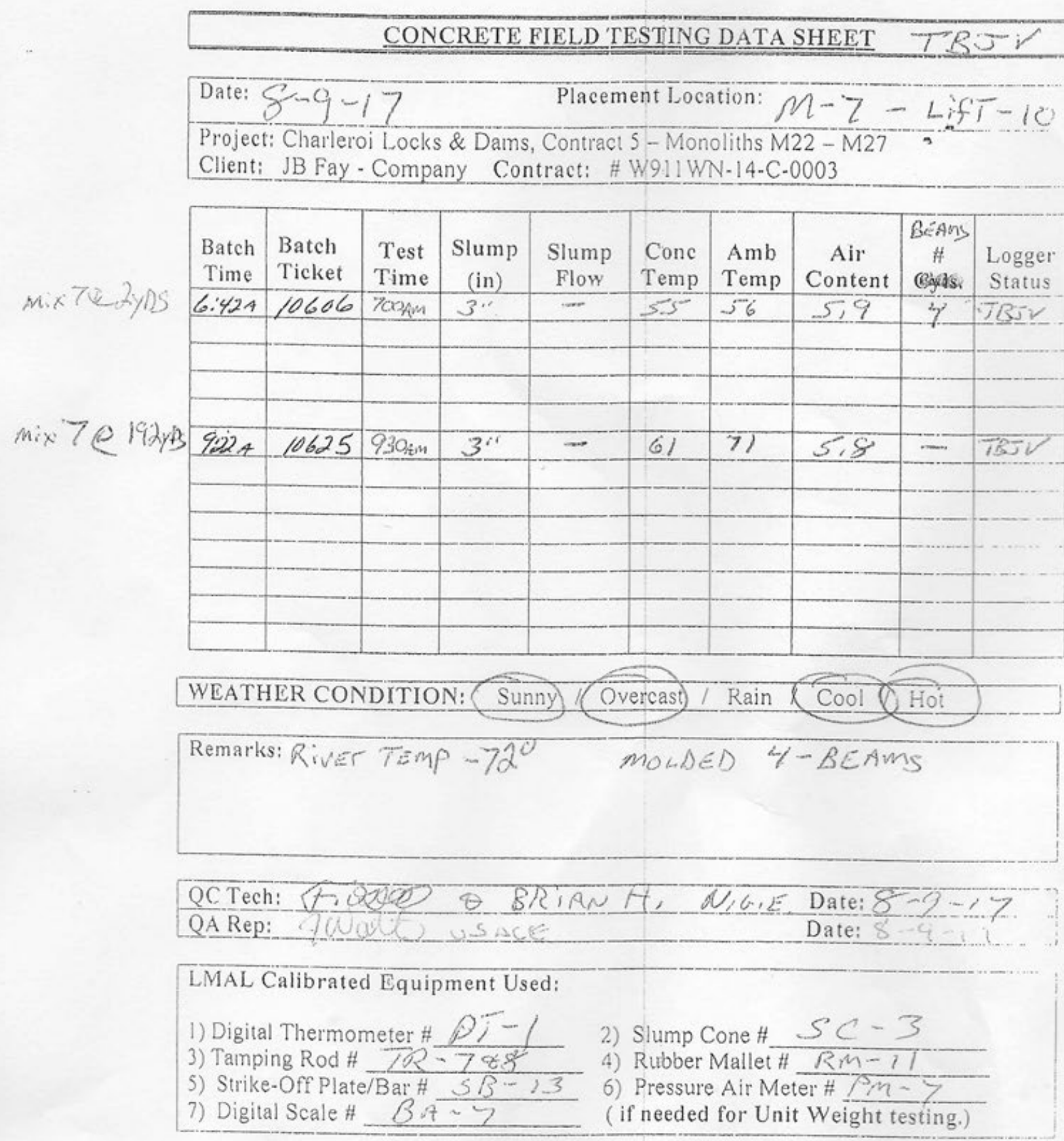




\section{Appendix C: Petrography Data Tables and XRD Patterns}

\section{Hanson Coarse Aggregate}

Table C1. Data table used in preparation of ASTM C-295 for the Hanson aggregate.

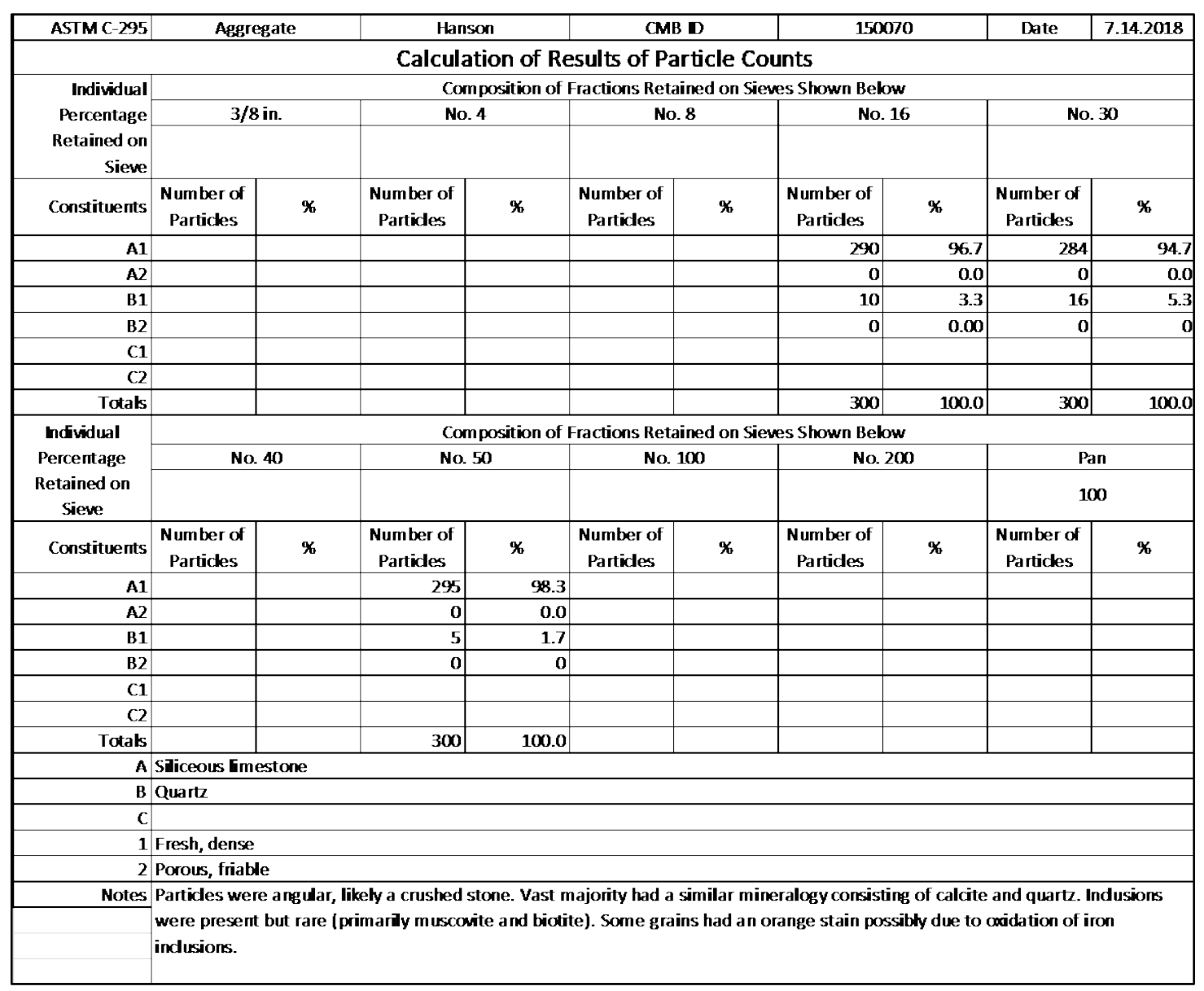


Figure C1. XRD pattern for Hanson with calculated weight percentages from whole pattern fitting.

\begin{tabular}{|c|c|c|c|c|c|}
\hline Phase ID (4) & Chemical Formula & PDF\# \# & Wt\% (esd) & RIR & $\mu$ \\
\hline Quartz & $\mathrm{SiO}_{2}$ & $98-000-0369$ & $37.7(0.0)$ & 4.30 & 140.6 \\
\hline Calcite & $\mathrm{CaCO}_{3}$ & $98-000-0141$ & $55.7(0.0)$ & 2.99 & 289.3 \\
\hline Muscovite $2 \mathrm{M}$ & $\mathrm{KAI}_{2}\left[\mathrm{Si}_{3} \mathrm{~A} \|\right] \mathrm{O}_{10}(\mathrm{OH})_{2}$ & $98-000-0321$ & $1.5(0.0)$ & 0.64 & 183.0 \\
\hline Biotite & $\mathrm{K}(\mathrm{Mg}, \mathrm{Fe})_{3} \mathrm{Al}\left[\mathrm{Si}_{3} \mathrm{O}_{10}\right] \mathrm{F}_{2}$ & $98-000-0117$ & $5.1(0.0)$ & 1.17 & 184.9 \\
\hline \multicolumn{6}{|c|}{$\mathrm{XRF}(\mathrm{Wt} \%): \mathrm{Fe} 2 \mathrm{O}=0.7 \%, \mathrm{CaO}=31.2 \%, \mathrm{~K} 2 \mathrm{O}=0.7 \%, \mathrm{SiO} 2=40.5 \%, \mathrm{Al} 2 \mathrm{O} 3=1.2 \%, \mathrm{MgO}=1.0 \%, \mathrm{CO} 2=24.5 \%$} \\
\hline
\end{tabular}

Refinement Iterations, Ready... ( $E=2.71 \%, E P S=0.5)$

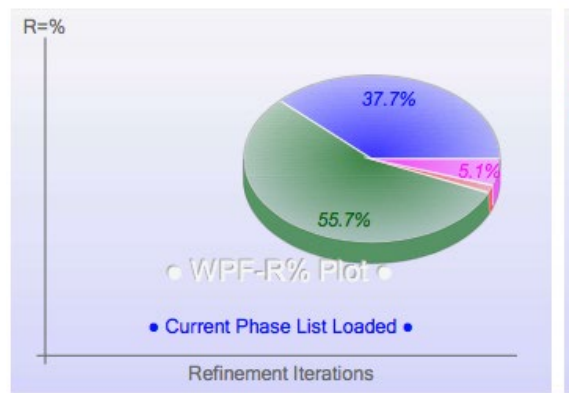

$\square$ Calcite $\bullet \mathrm{CaCO} 3$

Quartz • SiO2

Biotite $* K(M g, F e) 3 A /[S i 3 O$

Muscovite $2 \mathrm{M} \bullet \mathrm{KAl}[\mathrm{S}$ I3Al]O1010...
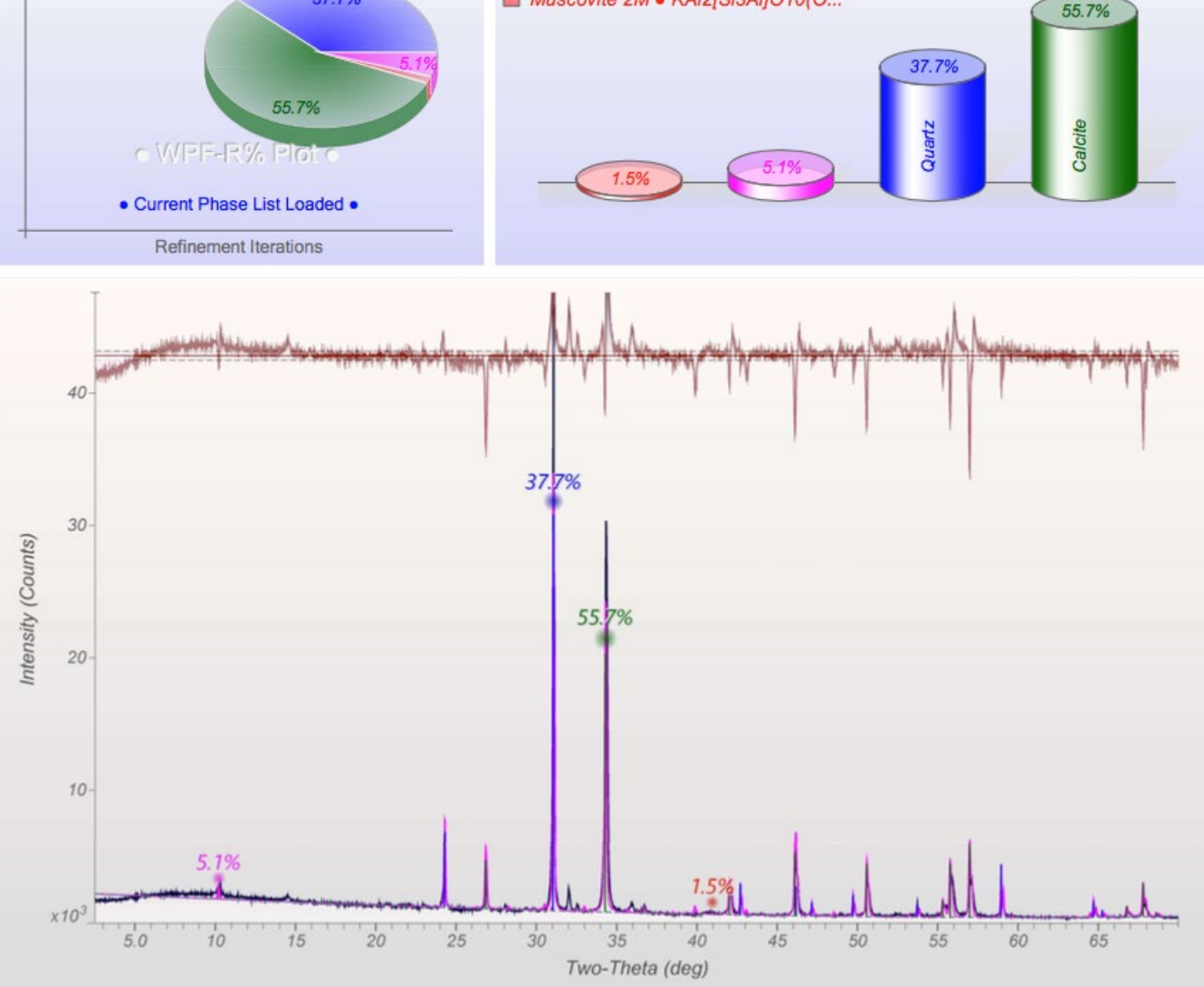


\section{Shelly Sand Fine Aggregate}

Table C2. Data table used in preparation of ASTM C-295 for the Shelley Sand aggregate.

\begin{tabular}{|c|c|c|c|c|c|c|c|c|c|c|}
\hline ASTM C-295 & \multicolumn{2}{|c|}{ Aggregate } & \multicolumn{2}{|c|}{ Shelly Sand } & \multicolumn{2}{|c|}{ CMB ID } & \multicolumn{2}{|c|}{160004} & Date & $7 / 5 / 18$ \\
\hline \multicolumn{11}{|c|}{ Calculation of Results of Particle Counts } \\
\hline Individual & \multicolumn{10}{|c|}{ Composition of Fractions Retained on Sieves Shown Below } \\
\hline Percentage & \multicolumn{2}{|c|}{$3 / 8$ in. } & \multicolumn{2}{|c|}{ No. 4} & \multicolumn{2}{|c|}{ No. 8} & \multicolumn{2}{|c|}{ No. 16} & \multicolumn{2}{|c|}{ No. 30} \\
\hline $\begin{array}{c}\text { Retained on } \\
\text { Sieve }\end{array}$ & \multicolumn{2}{|c|}{0} & \multicolumn{2}{|c|}{1.09} & \multicolumn{2}{|c|}{11.36} & \multicolumn{2}{|c|}{22.45} & \multicolumn{2}{|c|}{42.98} \\
\hline Constituents & \begin{tabular}{|c} 
Num ber of \\
Particles
\end{tabular} & $\%$ & $\begin{array}{c}\text { Number of } \\
\text { Particles }\end{array}$ & $\%$ & $\begin{array}{c}\text { Number of } \\
\text { Particles }\end{array}$ & $\%$ & $\begin{array}{c}\text { Number of } \\
\text { Particles }\end{array}$ & $\%$ & $\begin{array}{c}\text { Number of } \\
\text { Particles }\end{array}$ & $\%$ \\
\hline A1 & & & 70 & 23.3 & 68 & 22.7 & 70 & 23.3 & 136 & 45.3 \\
\hline $\mathrm{A} 2$ & & & 22 & 7.3 & 21 & 7.0 & 22 & 7.3 & 40 & 13.3 \\
\hline B1 & & & 145 & 48.3 & 155 & 51.7 & 132 & 44.0 & 80 & 26.7 \\
\hline B2 & & & 38 & 12.7 & 30 & 10.0 & 34 & 11.3 & 24 & 8.0 \\
\hline $\mathrm{C} 1$ & & & 6 & 2.0 & 12 & 4.0 & 24 & 8.0 & 14 & 4.7 \\
\hline$C 2$ & & & 19 & 6.3 & 14 & 4.7 & 18 & 6.0 & 6 & 2.0 \\
\hline Totals & & & 300 & 100.0 & 300 & 100.0 & 300 & 100.0 & 300 & 100.0 \\
\hline Individual & \multicolumn{10}{|c|}{ Composition of Fractions Retained on Sieves Shown Below } \\
\hline Percentage & \multicolumn{2}{|c|}{ No. 40} & \multicolumn{2}{|c|}{ No. 50} & \multicolumn{2}{|c|}{ No. 100} & \multicolumn{2}{|c|}{ No. 200} & \multicolumn{2}{|c|}{ Pan } \\
\hline $\begin{array}{l}\text { Retained on } \\
\text { Sieve }\end{array}$ & \multicolumn{2}{|c|}{70.4} & \multicolumn{2}{|c|}{88.33} & \multicolumn{2}{|c|}{98.12} & \multicolumn{2}{|c|}{99.73} & \multicolumn{2}{|c|}{100} \\
\hline Constituents & \begin{tabular}{|c|} 
Num ber of \\
Particles
\end{tabular} & $\%$ & \begin{tabular}{|c|} 
Number of \\
Particles
\end{tabular} & $\%$ & \begin{tabular}{|c|} 
Number of \\
Particles
\end{tabular} & $\%$ & \begin{tabular}{c|} 
Number of \\
Particles
\end{tabular} & $\%$ & $\begin{array}{c}\text { Number of } \\
\text { Particles }\end{array}$ & $\%$ \\
\hline $\mathrm{A} 1$ & & & 186 & 62.0 & 208 & 69.3 & & & & \\
\hline $\mathrm{A} 2$ & & & 66 & 22.0 & 58 & 19.3 & & & & \\
\hline B1 & & & 32 & 10.7 & 22 & 7.3 & & & & \\
\hline B2 & & & 16 & 5.3 & 12 & 4.0 & & & & \\
\hline $\mathrm{C} 1$ & & & 0 & 0.0 & 0 & 0.0 & & & & \\
\hline $\mathrm{C} 2$ & & & 0 & 0.0 & 0 & 0.0 & & & & \\
\hline Totals & & & 300 & 100.0 & 300 & 100.0 & & & & \\
\hline $\mathrm{A}$ & \multicolumn{10}{|l|}{ Quartz } \\
\hline B & \multicolumn{10}{|c|}{ Sandstone/Granite } \\
\hline C & Lim estone & & & & & & & & & \\
\hline 1 & Fresh, dense & & & & & & & & & \\
\hline 2 & Porous, friab & & & & & & & & & \\
\hline Notes & $\begin{array}{l}\text { A - varies in } \\
\text { is m ostly rou } \\
\text { three rock ty }\end{array}$ & $\begin{array}{l}\mathrm{r} \text { anc } \\
\text { subr } \\
\text { obse }\end{array}$ & $\begin{array}{l}\text { pe (angular to } \\
\text { but can vary, } \\
\text { has dendritic }\end{array}$ & $\begin{array}{l}\text { and), howe } \\
\text { rocrystals } \\
\text { cipitation }\end{array}$ & $\begin{array}{l}\text { ever appears } t \\
\text { are apparent } \\
\text { is likely } \mathrm{m} \text { ange }\end{array}$ & $\begin{array}{l}\text { e pure qua } \\
\text { many, hem } \\
\text { se oxide }\end{array}$ & $\begin{array}{l}\text { artz with } \mathrm{min} \\
\text { natite coating }\end{array}$ & $\begin{array}{l}\text { ccurences } \\
\text { mm on; C - }\end{array}$ & $\begin{array}{l}5 \text { of inclusions; } \\
\text { the most we }\end{array}$ & $\begin{array}{l}\text { B - shape } \\
\text { thered of }\end{array}$ \\
\hline
\end{tabular}


Figure C2. XRD pattern for Shelly with calculated weight percentages from whole pattern fitting.

\begin{tabular}{|c|c|c|c|c|c|}
\hline Phase ID (6) & Chemical Formula & PDF\#\# & Wt\% (esd) & RIR & $\mu$ \\
\hline Quartz & $\mathrm{SiO}_{2}$ & $98-000-0369$ & $69.0(0.8)$ & 4.30 & 140.5 \\
\hline Albite - low (?) & $\mathrm{Na}\left(\mathrm{AlSi}_{3} \mathrm{O}_{8}\right)$ & $98-000-0041$ & $14.0(0.6)$ & 0.66 & 132.3 \\
\hline Graphite (?) & $C$ & $98-000-0231$ & $6.2(0.5)$ & 2.50 & 16.3 \\
\hline Calcite (?) & $\mathrm{CaCO}_{3}$ & $98-000-0141$ & $4.4(0.2)$ & 2.99 & 289.3 \\
\hline Biotite & $\mathrm{K}(\mathrm{Mg}, \mathrm{Fe})_{3} \mathrm{Al}\left[\mathrm{Si}_{3} \mathrm{O}_{10}\right] \mathrm{F}_{2}$ & $98-000-0117$ & $5.8(0.0)$ & 1.17 & 184.9 \\
\hline \multirow[t]{2}{*}{ Muscovite 2M } & $\mathrm{KAl}_{2}\left[\mathrm{Si}_{3} \mathrm{Al}\right] \mathrm{O}_{10}(\mathrm{OH})_{2}$ & $98-000-0321$ & $0.7(0.0)$ & 0.64 & 183.0 \\
\hline & \multicolumn{5}{|c|}{ XRF(Wt $\%): \mathrm{Fe} 2 \mathrm{O} 3=0.8 \%, \mathrm{CaO}=2.5 \%, \mathrm{~K} 2 \mathrm{O}=0.7 \%, \mathrm{SiO} 2=81.3 \%, \mathrm{Al} 2 \mathrm{O}=3.6 \%, \mathrm{MgO}=1.2 \%, \mathrm{Na} 2 \mathrm{O}=1.7 \%, \mathrm{CO} 2=24.7 \%$} \\
\hline
\end{tabular}

Refinement Halted $(R / E=5.5)$, Round $=4$, Iter $=6, P=20, R=10.08 \%(E=2.20 \%$, $E P S=0.5)$
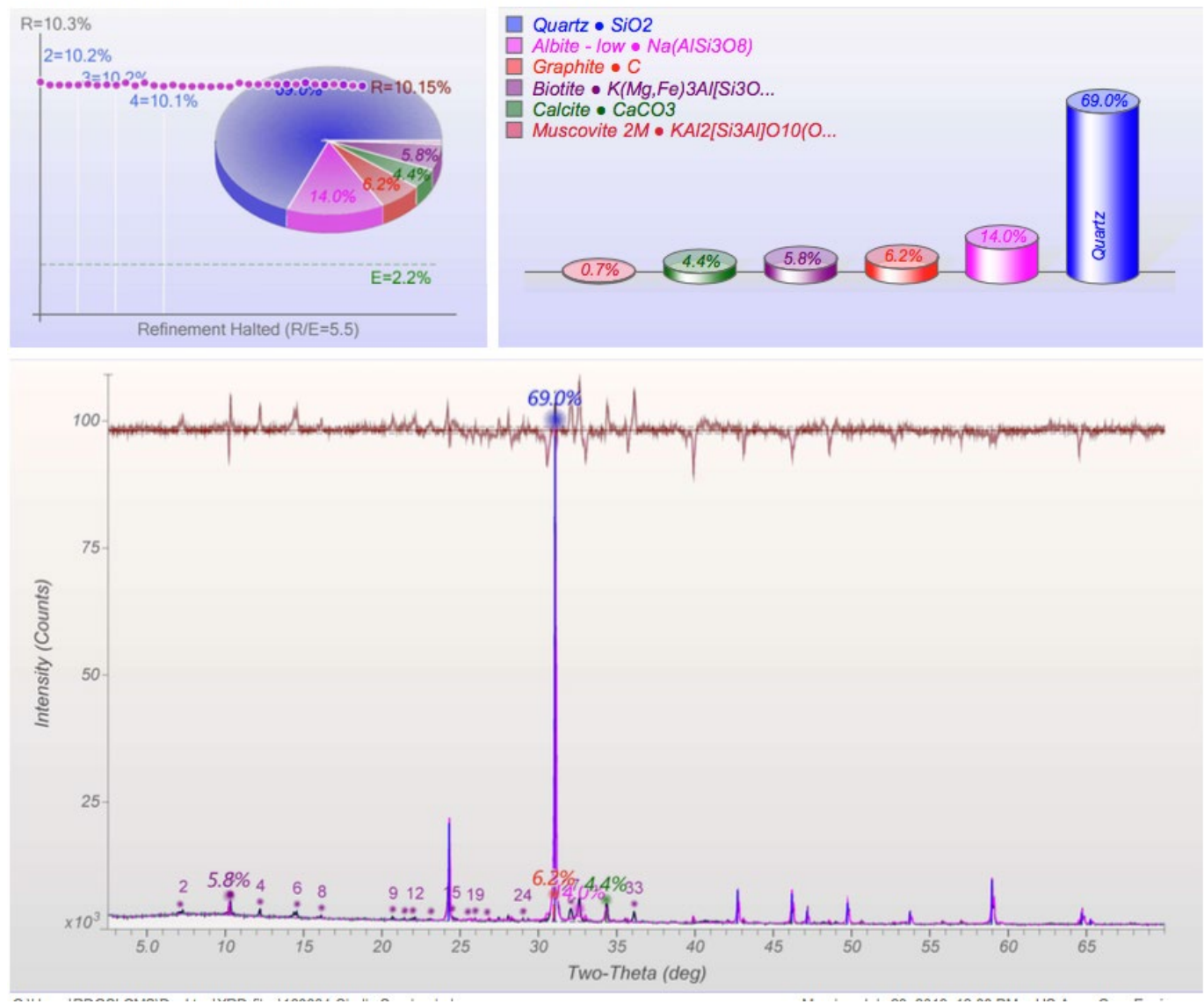


\section{Georgetown Sand Fine Aggregate}

Table C3. Data table used in preparation of ASTM C-295 for the Georgetown aggregate.

\begin{tabular}{|c|c|c|c|c|c|c|c|c|c|c|}
\hline ASTM C-295 & \multicolumn{2}{|c|}{ Aggregate } & \multicolumn{2}{|c|}{ Georgetown } & \multicolumn{2}{|c|}{ CMB ID } & \multicolumn{2}{|c|}{150069} & Date & $7 / 6 / 18$ \\
\hline \multicolumn{11}{|c|}{ Calculation of Results of Particle Counts } \\
\hline Individual & \multicolumn{10}{|c|}{ Composition of Fractions Retained on Sieves Shown Below } \\
\hline Percentage & \multicolumn{2}{|c|}{$3 / 8$ in. } & \multicolumn{2}{|c|}{ No. 4} & \multicolumn{2}{|c|}{ No. 8} & \multicolumn{2}{|c|}{ No. 16} & \multicolumn{2}{|c|}{ No. 30} \\
\hline $\begin{array}{c}\text { Retained on } \\
\text { Sieve }\end{array}$ & \multicolumn{2}{|c|}{0} & \multicolumn{2}{|c|}{2.0} & \multicolumn{2}{|c|}{14.0} & \multicolumn{2}{|c|}{26.2} & \multicolumn{2}{|c|}{44.8} \\
\hline Constituents & $\begin{array}{c}\text { Num ber of } \\
\text { Particles }\end{array}$ & $\%$ & $\begin{array}{c}\text { Number of } \\
\text { Particles }\end{array}$ & $\%$ & $\begin{array}{c}\text { Number of } \\
\text { Particles }\end{array}$ & $\%$ & $\begin{array}{c}\text { Number of } \\
\text { Particles }\end{array}$ & $\%$ & $\begin{array}{c}\text { Number of } \\
\text { Particles }\end{array}$ & $\%$ \\
\hline A1 & & & & & 76 & 25.3 & 105 & 35.0 & 179 & 59.7 \\
\hline A2 & & & & & 16 & 5.3 & 38 & 12.7 & 20 & 6.7 \\
\hline B1 & & & & & 144 & 48.0 & 106 & 35.3 & 69 & 23.0 \\
\hline B2 & & & & & 42 & 14.0 & 21 & 7.0 & 16 & 5.3 \\
\hline $\mathrm{C} 1$ & & & & & 16 & 5.3 & 26 & 8.7 & 16 & 5.3 \\
\hline $\mathrm{C} 2$ & & & & & 6 & 2.0 & 4 & 1.3 & 0 & 0.0 \\
\hline Totals & & & & & 300 & & 300 & & 300 & \\
\hline Individual & \multicolumn{10}{|c|}{ Composition of Fractions Retained on Sieves Shown Below } \\
\hline Percentage & \multicolumn{2}{|c|}{ No. 40} & \multicolumn{2}{|c|}{ No. 50} & \multicolumn{2}{|c|}{ No. 100} & \multicolumn{2}{|c|}{ No. 200} & \multicolumn{2}{|c|}{ Pan } \\
\hline $\begin{array}{c}\text { Retained on } \\
\text { Sieve }\end{array}$ & \multicolumn{2}{|c|}{67.1} & \multicolumn{2}{|c|}{86.4} & \multicolumn{2}{|c|}{97.5} & \multicolumn{2}{|c|}{99.7} & \multicolumn{2}{|c|}{100.0} \\
\hline Constituents & $\begin{array}{c}\text { Num ber of } \\
\text { Particles }\end{array}$ & $\%$ & $\begin{array}{c}\text { Number of } \\
\text { Particles }\end{array}$ & $\%$ & \begin{tabular}{|c}
$\begin{array}{c}\text { Number of } \\
\text { Particles }\end{array}$ \\
\end{tabular} & $\%$ & \begin{tabular}{|c|} 
Number of \\
Particles
\end{tabular} & $\%$ & $\begin{array}{c}\text { Number of } \\
\text { Particles }\end{array}$ & $\%$ \\
\hline A1 & & & 190 & 63.3 & 242 & 80.7 & & & & \\
\hline $\mathrm{A} 2$ & & & 52 & 17.3 & 22 & 7.3 & & & & \\
\hline B1 & & & 38 & 12.7 & 24 & 8.0 & & & & \\
\hline B2 & & & 12 & 4.0 & 12 & 4.0 & & & & \\
\hline $\mathrm{C} 1$ & & & 6 & 2.0 & 0 & 0.0 & & & & \\
\hline$C 2$ & & & 2 & 0.7 & 0 & 0.0 & & & & \\
\hline Totals & & & 300 & & 300 & & & & & \\
\hline A & \multicolumn{10}{|l|}{ Quartz } \\
\hline$B$ & Sandstone/C & & & & & & & & & \\
\hline$C$ & Lim estone & & & & & & & & & \\
\hline 1 & Fresh, dense & & & & & & & & & \\
\hline 2 & Porous, friab & & & & & & & & & \\
\hline Notes & A - range fro & ngul & round with va & ions in lus & ster (glassy to & aque), ofte & en have an or & ge hue anc & are dense, $m$ & stly quartz \\
\hline & $\begin{array}{l}\text { with few inc } \\
\text { crystals that }\end{array}$ & $\begin{array}{l}\text { ons } / \mathrm{h} \\
\text { cem }\end{array}$ & $\begin{array}{l}\text { ogenities; B - } \\
\text { d together; C- }\end{array}$ & $\begin{array}{l}\text { tly round, } \\
\text { en a very }\end{array}$ & $\begin{array}{l}/ \text { sub-round wh } \\
\text { porous textur }\end{array}$ & $\begin{array}{l}\text { microcrys } \\
\text { dicating } \mathrm{di}\end{array}$ & $\begin{array}{l}\text { stalline, som } \\
\text { lissolution, so }\end{array}$ & $\begin{array}{l}\text { ave visible } \\
\text { fossilifer }\end{array}$ & $\begin{array}{l}\text { quartz and fe } \\
\text { ous grains pre }\end{array}$ & $\begin{array}{l}\text { dspar } \\
\text { ent }\end{array}$ \\
\hline
\end{tabular}


Figure C3. XRD pattern for Georgetown with calculated weight percentages from whole pattern fitting.

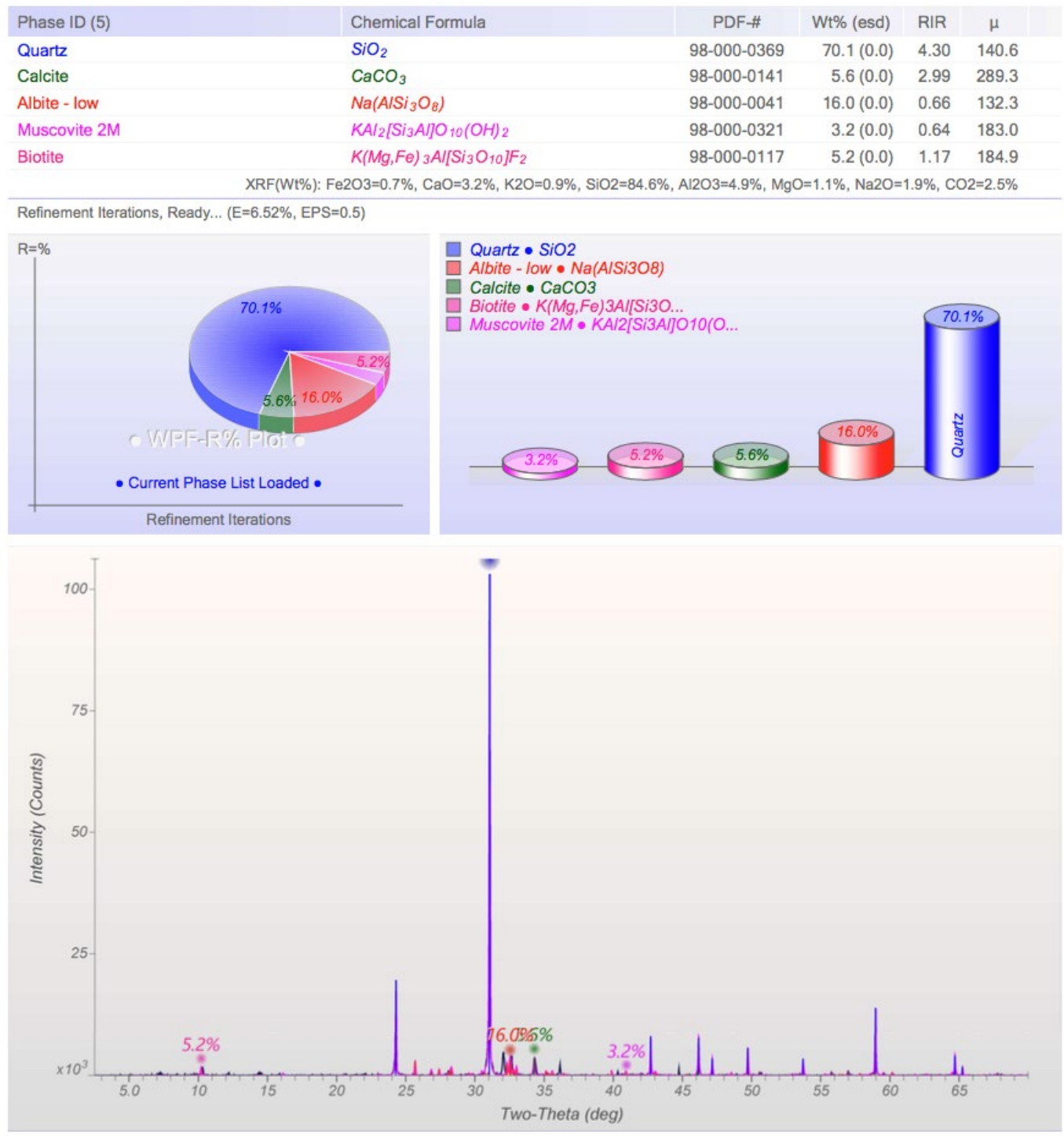




\section{Appendix D: Cementitious Material Reports}

\section{ASTM C150 Report: Armstrong Type II (MH) Portland Cement}

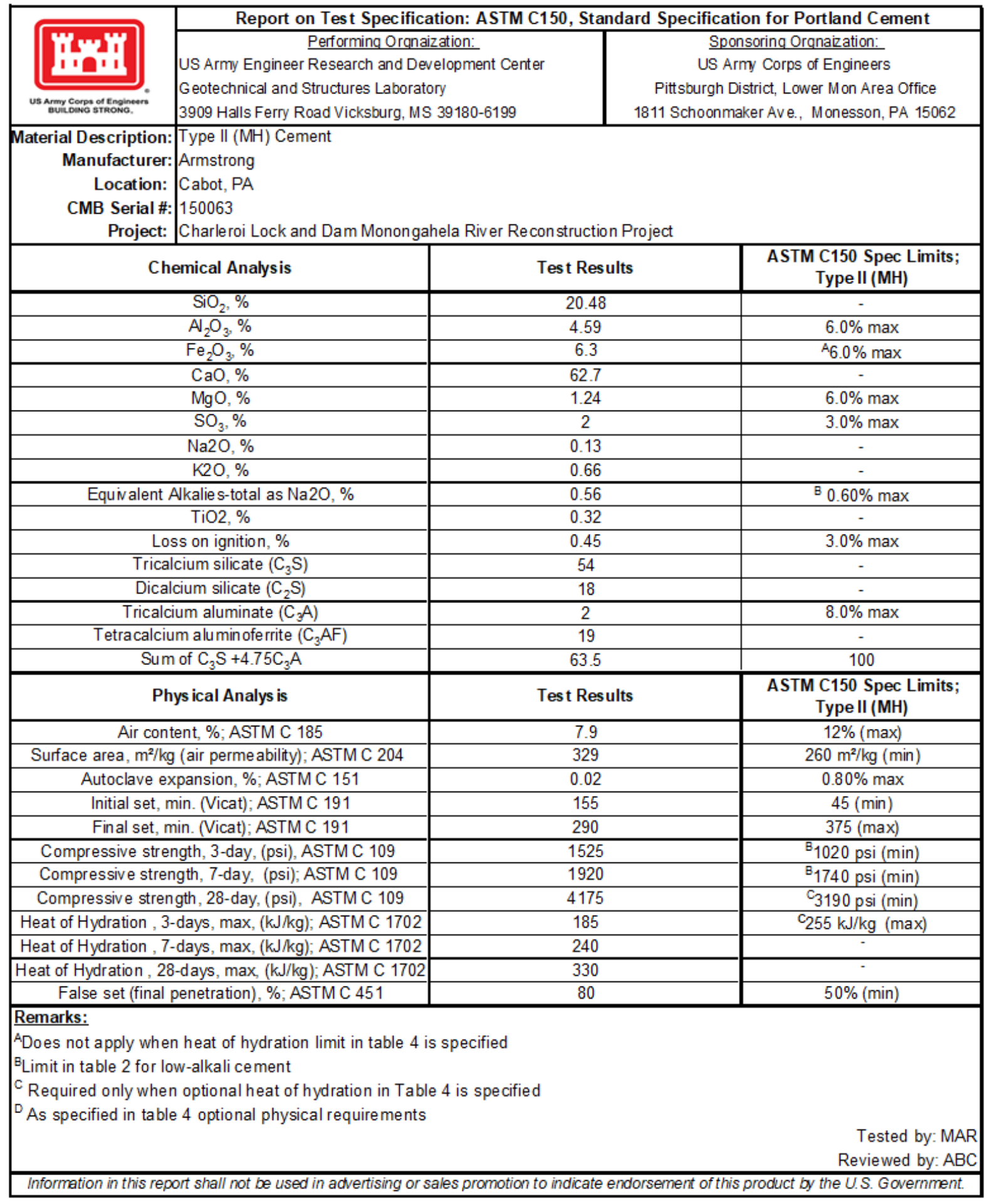




\section{ASTM C618 Report: Fort Martin Class F Fly Ash}

\begin{tabular}{|c|c|c|c|c|}
\hline & Report on Test Specification: & \multicolumn{3}{|c|}{ ASTM C 618, Standard Specification for Coal Fly Ash } \\
\hline 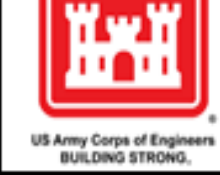 & $\begin{array}{l}\text { Performing Orgnaization: } \\
\text { US Army Engineer Research and Development Cen } \\
\text { Geotechnical and Stuctures Labor atory (CEERD-G) } \\
3909 \text { Halls Ferry Road Vioks burg, MS } 39180-6199\end{array}$ & $\begin{array}{l}\text { US Arm, } \\
\text { Pitts bur } \\
1811 \mathrm{So}\end{array}$ & $\begin{array}{l}\text { Soonsoring Orgn } \\
\text { Corps of Engineer: } \\
\text { h District, Lower M } \\
\text { oonmaker Ave., M }\end{array}$ & $\begin{array}{l}\text { Isization: } \\
\text { Ion Area Office } \\
\text { Monesson, PA } 15062\end{array}$ \\
\hline $\begin{array}{r}\text { Material Descript } \\
\text { Manufactu } \\
\text { Locati } \\
\text { CMB Seri } \\
\text { Proje }\end{array}$ & $\begin{array}{l}\text { Class F FlyAsh } \\
\text { Ft Martin Plant from Headwater Reasources } \\
\text { Maidsville, WV } \\
150064 \\
\text { Charleroi Lock and Dam Monongahela River Re }\end{array}$ & nstruction Project & & \\
\hline & Chemical Analysis & Test Results & Spec & Limits; Class F \\
\hline & $\mathrm{SiO}_{2}, \%$ & 52.6 & & - \\
\hline & $\mathrm{Al}_{2} \mathrm{O}_{3}, \%$ & 22.5 & & - \\
\hline & $\mathrm{Fe}_{2} \mathrm{O}_{3}, \%$ & 13.5 & & - \\
\hline & Sum, \% & 88.6 & & $70.0 \% \mathrm{~min}$ \\
\hline & $\mathrm{Na} 20, \%$ & 2.49 & & - \\
\hline & $\mathrm{K} 20, \%$ & 2 & & - \\
\hline & $\mathrm{CaO}, \%$ & 1.1 & & - \\
\hline & $\mathrm{MgO}, \%$ & 0.9 & & - \\
\hline & $\mathrm{SO}_{3}, \%$ & 0.3 & & $5.0 \% \max$ \\
\hline & Loss on ignition, $\%$ & 3.1 & & $6.0 \% \max$ \\
\hline & Moisture Content, \% & 0.13 & & $3.0 \% \max$ \\
\hline & Physical Analysis & Test Results & Spec & Limits; Class F \\
\hline Streng & Activity Index, ( \%) 7-day, ASTIM C311 & 64 & & $75 \% \mathrm{~min}$ \\
\hline Streng & divity Index, (\%) 28-day, ASTIM C311 & 65 & & $75 \% \min$ \\
\hline Water $\mathrm{P}$ & uirement, \% control, ASTM C 311, C109 & 100 & & $105 \% \max$ \\
\hline & Specific Gravity, ASTM C188 & 2.52 & & $5 \% \max$ \\
\hline Auto & e Soundness, \%, ASTM C311, C151 & 0.001 & & $0.8 \% \max$ \\
\hline & s, \% Retained on \#325; ASTM C311 & 23.85 & & $34 \% \max$ \\
\hline Supp & nentary 0 ptional Physical Analysis & Test Results & Spec & Limits; Class F \\
\hline Increase of dryir & hrinkage of mortar bars at 28 days, ASTM C618 & 0.001 & & - \\
\hline Uniformity & quirement, amount of Vinsol, ASTM C618 & 0.2 & & - \\
\hline \multicolumn{5}{|l|}{ Remarks: } \\
\hline \multicolumn{2}{|c|}{${ }^{1}$ Amstrong Type II (MH) projed cement used for reference cement } & \multicolumn{3}{|c|}{$\begin{array}{ll}\text { Tested by: } & \text { MAR } \\
\text { Reviewed by. } & \text { ABC }\end{array}$} \\
\hline
\end{tabular}




\section{ASTM C618 Report: Sammis Class F Fly Ash}

\begin{tabular}{|c|c|c|c|c|}
\hline & Report on Test Specification: & \multicolumn{3}{|c|}{ ASTM C 618, Standard Specification for Coal Fly Ash } \\
\hline 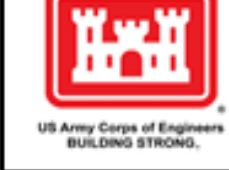 & $\begin{array}{l}\text { Performing Orgnaization: } \\
\text { US Army Engineer Research and Development Cer } \\
\text { Geotechnical and Structures Laboratory (CEERD-G } \\
3909 \text { Halls Ferry Road Vioksburg, MS 39180-6199 }\end{array}$ & $\begin{array}{l}\text { US Arm } \\
\text { Pitts bur } \\
1811 \mathrm{So}\end{array}$ & $\begin{array}{l}\text { Soons oring Org } \\
\text { Corps of Enginee } \\
\text { District, Lower I } \\
\text { Donmaker Ave., I }\end{array}$ & $\begin{array}{l}\text { gnaization: } \\
\text { ers } \\
\text { Mon Area Office } \\
\text { Monesson, PA } 15062\end{array}$ \\
\hline $\begin{array}{r}\text { Material Descripti } \\
\text { Manufactu } \\
\text { Locati } \\
\text { CMB Seria } \\
\text { Proje }\end{array}$ & $\begin{array}{l}\text { Class F Fly Ash } \\
\text { W.H. Sammis Plant, Headwaters Reasources } \\
\text { Stratton, } \mathrm{OH} \\
150065 \\
\text { : Charleroi Lock and Dam Monongahela River Re }\end{array}$ & Istruction Projed & & \\
\hline & Chemical Analysis & Test Results & Spe & ec Limits Class F \\
\hline & $\mathrm{SiO}_{2}, \%$ & 44.2 & & - \\
\hline & $\mathrm{Al}_{2} \mathrm{O}_{3}, \%$ & 20.2 & & - \\
\hline & $\mathrm{Fe}_{2} \mathrm{O}_{3}, \%$ & 242 & & - \\
\hline & Sum, $\%$ & 88.6 & & $70.0 \% \min$ \\
\hline & $\mathrm{Na} 20, \%$ & 2.87 & & - \\
\hline & $\mathrm{K} 20, \%$ & 2.05 & & - \\
\hline & $\mathrm{CaO}, \%$ & 0 & & - \\
\hline & $\mathrm{MgO}, \%$ & 0.9 & & - \\
\hline & $\mathrm{SO}_{3}, \%$ & 0.6 & & $5.0 \% \max$ \\
\hline & Loss on ignition, $\%$ & 2.99 & & $6.0 \% \max$ \\
\hline & Moisture Content, \% & 0.11 & & $3.0 \% \max$ \\
\hline & Physical Analysis & Test Results & Spe & ec Limits Class F \\
\hline Streng & Adtivity Index, (\%) 7-day, ASTM C311 & 71 & & $75 \% \min$ \\
\hline Strengt & Adtivity Index, (\%) 28-day, ASTM C311 & 72 & & $75 \% \min$ \\
\hline Water $\mathrm{R}$ & fuirement, \% control, ASTM C 311, C109 & 100 & & $105 \% \max$ \\
\hline & Specific Gravity, ASTM C188 & 2.6 & & $5 \% \max$ \\
\hline Autoo & ve Soundness, \%, ASTM C311, C151 & 0.001 & & $0.8 \% \max$ \\
\hline Finer & ss, \% Retained on \#325; ASTM C311 & 25.92 & & $34 \% \max$ \\
\hline Supp & mentary 0 ptional Physical Analysis & Test Results & Spe & ec Limits, Class F \\
\hline Increase of dryin & shrinkage of mortar bars at 28 days, ASTM C 618 & 0.05 & & - \\
\hline Uniformity & equirement, amount of Vinsol, ASTM C618 & 0.2 & & - \\
\hline Remarks: & & & & \\
\hline${ }^{2}$ Armstr & g Type II (MH) project cement used for reference & nent & $\begin{array}{l}\text { Tested by. } \\
\text { Reviewed by. }\end{array}$ & $\begin{array}{l}\text { MAR } \\
\quad A B C\end{array}$ \\
\hline
\end{tabular}




\section{ASTM C618 Report: Longview Class F Fly Ash}

\begin{tabular}{|c|c|c|c|}
\hline \multirow{2}{*}{ 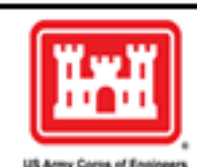 } & Report on Test Specification: & \multicolumn{2}{|c|}{ ASTM C 618, Standard Specification for Coal Fly Ash } \\
\hline & $\begin{array}{l}\text { Perborming Orgnaization: } \\
\text { US Army Engineer Research and Development Cen ter } \\
\text { Geotechnical and Structures Laboratory (CEERD-GMC) } \\
3909 \text { Halls Ferry Road Vidksburg, MS } 39180-6199\end{array}$ & \begin{tabular}{|l} 
US Army \\
Pitteburg \\
$1811 \mathrm{Scl}$
\end{tabular} & $\begin{array}{l}\text { Spon soring Orgnaization: } \\
\text { US Army Corps of Engineers } \\
\text { Pitteburgh District, Lower Mon Area O fice } \\
1811 \text { Schoonmaker Ave., Monesson, PA } 15062\end{array}$ \\
\hline $\begin{array}{r}\text { Material Descr } \\
\text { Manufar } \\
\text { Loc } \\
\mathrm{CMB} \mathrm{Se} \\
\mathrm{Pr}\end{array}$ & $\begin{array}{l}\text { Class F Fly Ash } \\
\text { Longview } \\
\text { Maidsville, WV } \\
180005 \\
\text { Charler oi Lock and Dam Monongahela River } R\end{array}$ & econstruction Projed & \\
\hline & Chemical Analysis & Test Results & $\begin{array}{c}\text { ASTM C618 } \\
\text { Spec Limits; Class F }\end{array}$ \\
\hline & $\mathrm{SiO}_{2} \%$ & 50.81 & - \\
\hline & $\mathrm{Al}_{2} \mathrm{O}_{3} \%$ & 21.75 & - \\
\hline & $\mathrm{Fe}_{2} \mathrm{O}_{3}, \%$ & 15.64 & - \\
\hline & Sum, \% & 88.2 & $70.0 \% \mathrm{~min}$ \\
\hline & $\mathrm{Na} 2 \mathrm{O}, \%$ & 0.62 & - \\
\hline & $\mathrm{K} 2 \mathrm{O}, \%$ & 2.38 & - \\
\hline & $\mathrm{CaO}, \%$ & 3.37 & - \\
\hline & $\mathrm{MgO}, \%$ & 1.07 & - \\
\hline & $\mathrm{SO}_{3} \%$ & 0.92 & $5.0 \% \max$ \\
\hline & Loss on ignition, $\%$ & 1.9 & $6.0 \% \max$ \\
\hline & Moisture Content, \% & 0.13 & $3.0 \% \mathrm{max}$ \\
\hline & Phy sical Analy sis & Test Results & $\begin{array}{c}\text { ASTM C618 } \\
\text { Spec Limits; Class F }\end{array}$ \\
\hline & Initial Test & \multicolumn{2}{|c|}{-} \\
\hline Compressi & ngth, (psi) 7-day, ${ }^{2}$ Reference ASTM C311 & 2410 & - \\
\hline Compressiv & gth, (psi) 28-day, 'R eference, ASTM C311 & 3820 & - \\
\hline Compressive & th, (psi) 7-dgy, Fly Ash/Cement, ASTM C311 & 1640 & - \\
\hline Compressive & h. (psi) 28-dsy, Fly As h/Cement, ASTM C311 & 2980 & - \\
\hline Stren & tivity Index, ( \%) 7-day, ASTM C311 & 68 & $75 \% \min$ \\
\hline Streng & ivity Index, (\%) 28-day, ASTM C311 & 78 & $75 \%$ min \\
\hline & Second Test & \multicolumn{2}{|c|}{-} \\
\hline Compressi & ngth, (psi) 7-day, ${ }^{1}$ Reference ASTM C311 & 2520 & - \\
\hline Compressiv & gth, (psi) 28-dgy, 'R eference, ASTM C311 & 4080 & - \\
\hline Compressive & th, (psi) 7-dgy, Fly Ash/Cement, ASTM C311 & 1690 & - \\
\hline Compressives & h, (psi) 28-day, Fly As h/Cement, ASTM C311 & 3190 & - \\
\hline Stren & tivity Index, ( \%) 7-day, ASTM C311 & 87 & $75 \% \min$ \\
\hline Streng & ivity Index, (\%) 28-day, ASTM C311 & 78 & $75 \% \mathrm{~min}$ \\
\hline Water & ement, \% contr ol, ASTM C 311, C109 & 99 & $105 \% \max$ \\
\hline & vecific Gravity, ASTM C 188 & 2.34 & $5 \% \max$ \\
\hline Auto & Soundness, \%, ASTM C311, C151 & -0.03 & $0.8 \% \max$ \\
\hline Fine & \% Retained on $\# 325$; ASTM C311 & 38.6 & $34 \% \max$ \\
\hline (Re-Test & ness, 96 Retained on \#325; ASTM C311 & 38.5 & $34 \% \max$ \\
\hline Sup & ntary Optional Physical Analysis & Test Results & $\begin{array}{c}\text { ASTM C618 } \\
\text { Spec Limits; Class F } \\
\end{array}$ \\
\hline Increase of dry & inkage of mortar bars at 28 days, ASTM C818 & 0.01 & - \\
\hline Uniformit & uirement, amount of Vins d, ASTM C818 & $0.16 \mathrm{~g}$ & - \\
\hline \multicolumn{4}{|l|}{ Remarks: } \\
\hline 'Arms trong Type & -1) project cement us ed for refer ence cement & & $\begin{array}{l}\text { by: } \\
\text { ed by: }\end{array}$ \\
\hline
\end{tabular}




\section{ASTM C618 Report: Brandon Shores Class F Fly Ash}

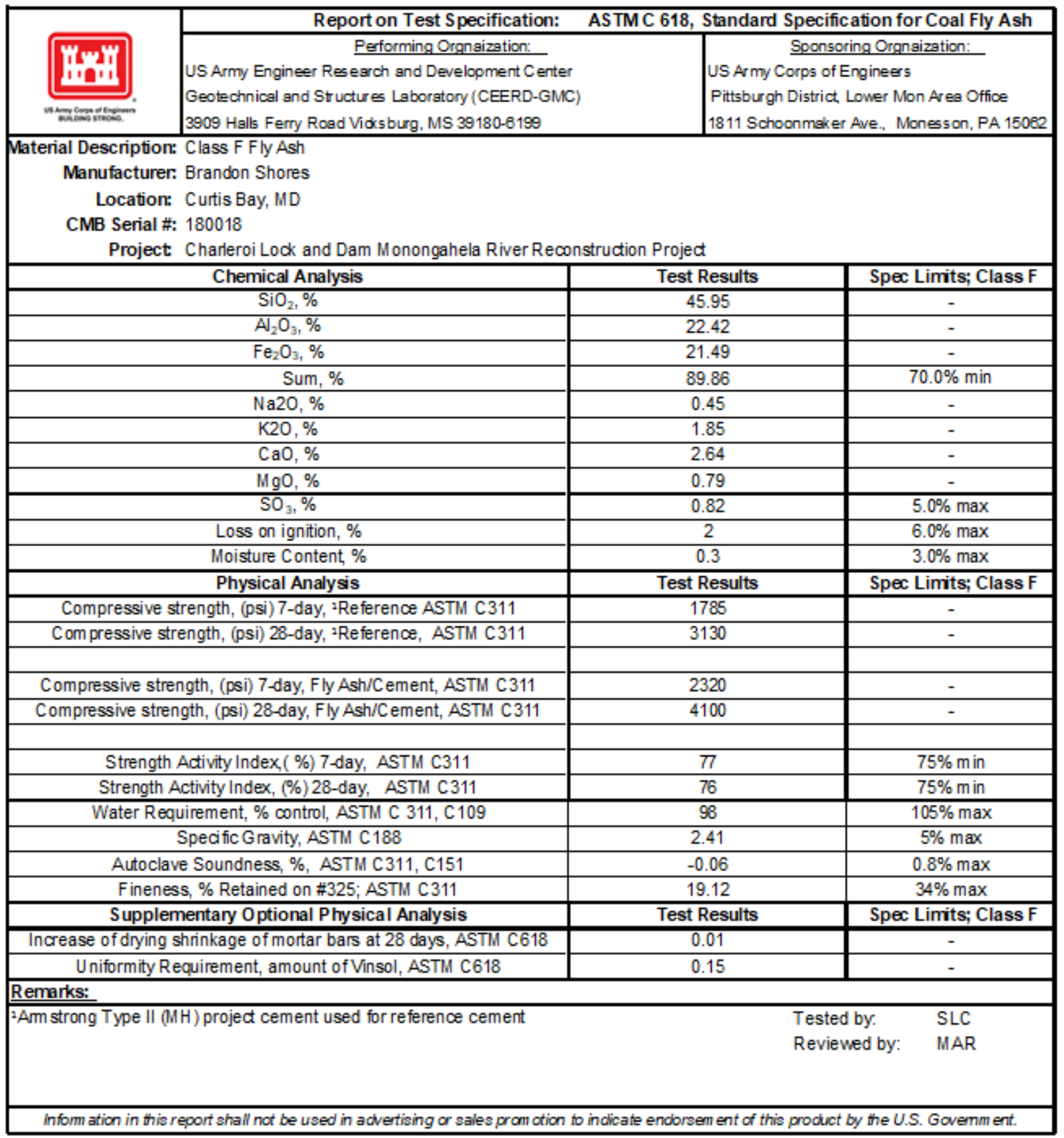




\section{ASTM C989 Report: Argos-Essroc Slag Cement, Grade 100}

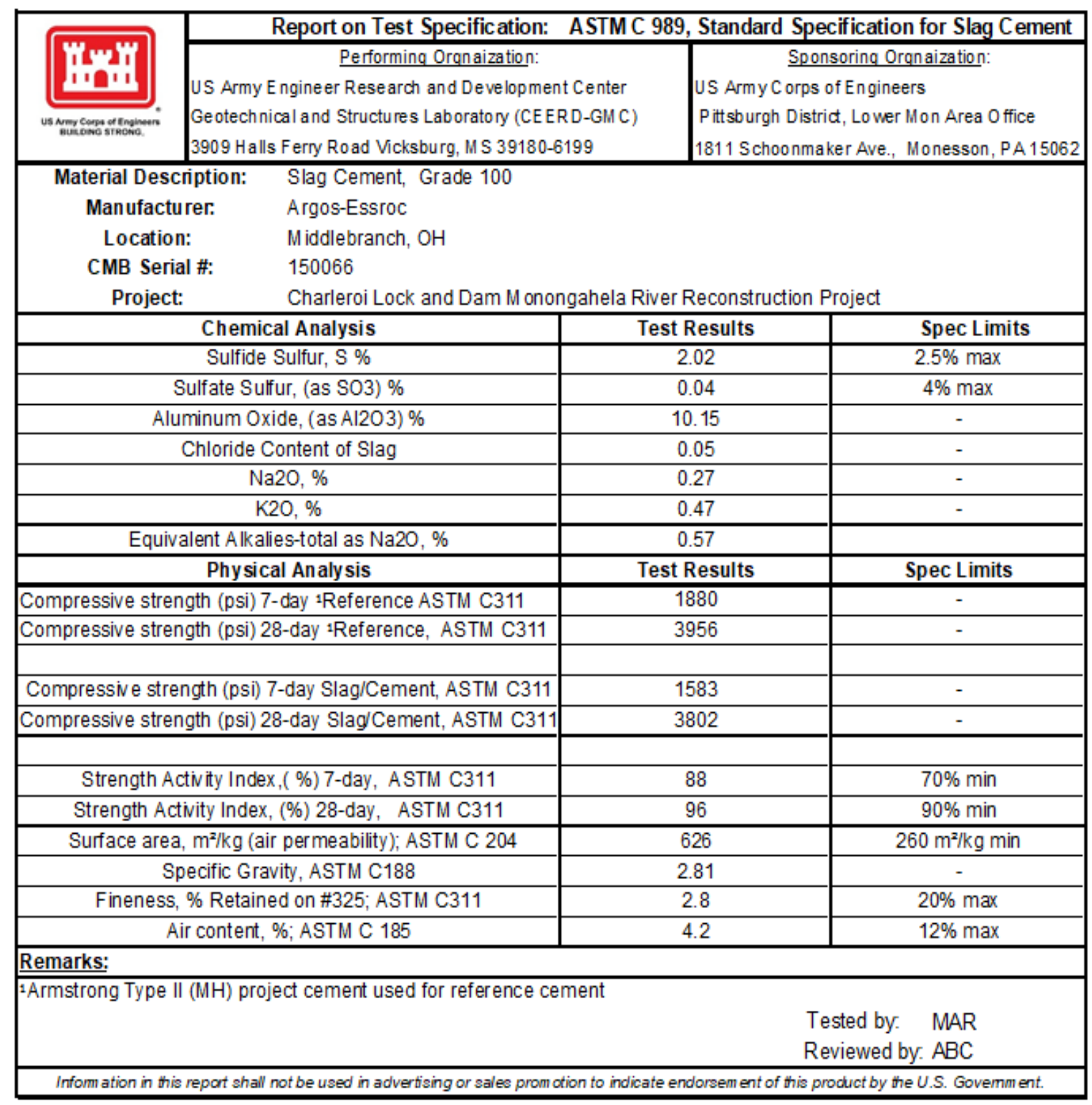




\section{ASTM C1240: Elkem Materials Silica Fume}

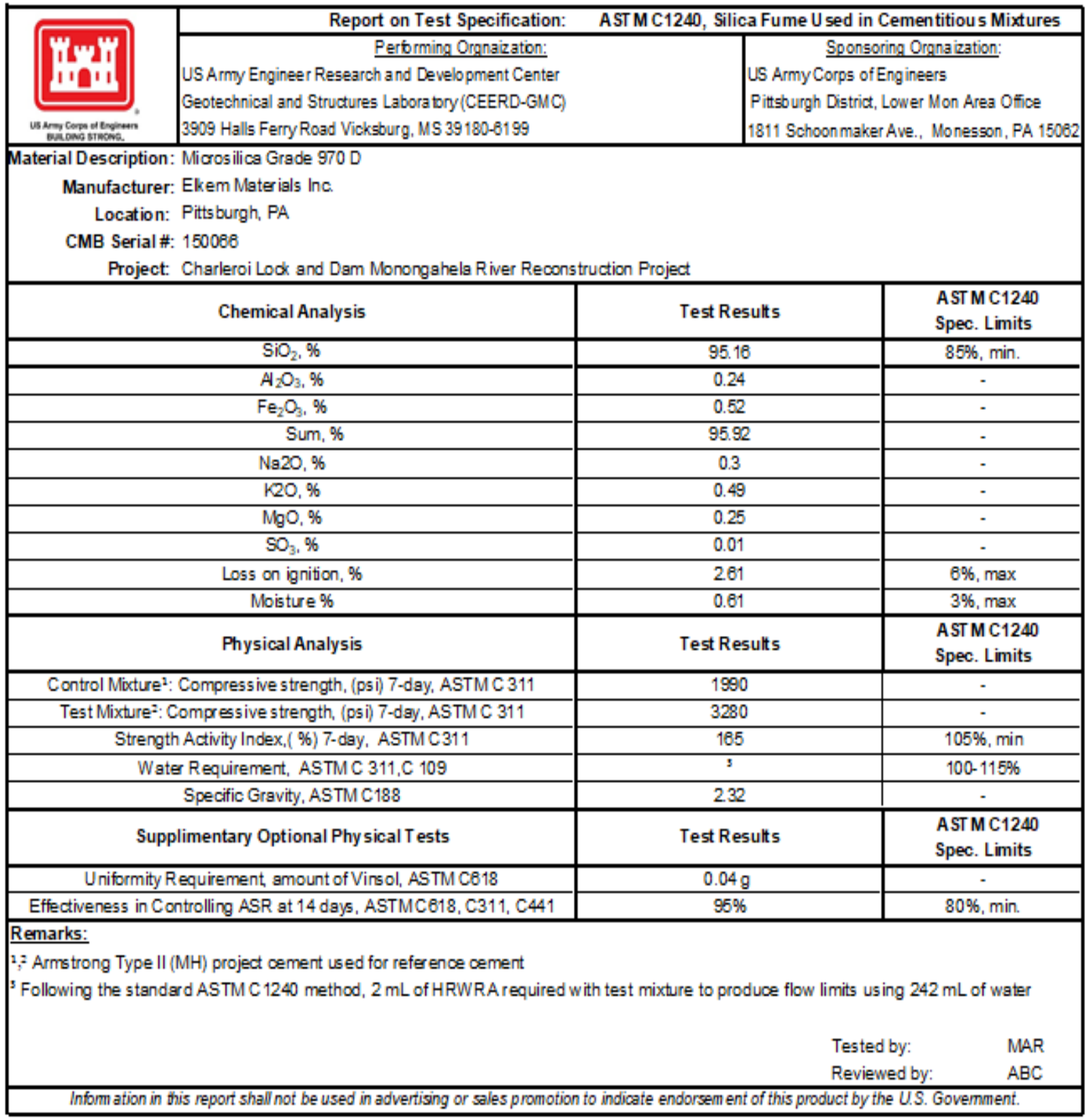




\title{
Appendix E: Admixture Reports
}

\author{
The Euclid Chemical Company
}

\section{EUCON AEA-92}

Air Entraining Agent For Concrete

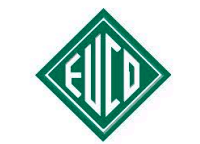

EUCLID CHEMICAL

\section{DESCRIPTION}

EUCON AEA-92 is formulated for use as an air entraining admixture for concrete of all types and is manufactured under rigid control which assures uniform and precise performance. It should be added to the mix independently and not with other admixtures.

\section{Primary Applications}

- Ready mix concrete

- Structural concrete

- Mass concrete

- Paving concrete

- All exterior concrete

\section{FEATURES/BENEFITS}

- Provides a stable air void system with proper bubble size and spacing. This air void system protects concrete against damage caused by repeated freeze/thaw cycles

- Concrete is made more resistant to de-icing salts, sulfate attack and corrosive water

- Less mixing water can be used per yard (meter) of concrete and placeability is improved

- Minimizes bleeding and segregation of the concrete

\section{TECHNICAL INFORMATION}

EUCON AEA-92 is an aqueous solution compound of synthetic organic chemicals. It is compatible with concrete mixes containing calcium chloride, water reducing admixtures, retarding admixtures, or high range water reducers.

\section{PACKaging}

EUCON AEA-92 is packaged in bulk, $275 \mathrm{gal}(1041 \mathrm{~L})$ totes, $55 \mathrm{gal}(208 \mathrm{~L})$ drums and 5 gal $(18.9 \mathrm{~L})$ pails.

\section{SHELF LIFE}

2 years in original, unopened package.

\section{SPECIFICATIONS/COMPLIANCES}

EUCON AEA-92 meets or exceeds the requirements of the following specifications:

- Corps of Engineers Specification CRD C-13

- ASTM Specification C 260

- AASHTO Specification M 154

- ANSI/NSF STD 61 
The Euclid Chemical Company

\section{EUCON RETARDER 75}

CONCRETE WATER Reducing Set Controlling Retarder

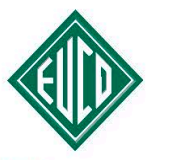

EUCLID CHEMICAL

\section{DESCRIPTION}

EUCON RETARDER 75 is a synthetically produced liquid water-reducing and set retarding admixture for concrete. EUCON RETARDER 75 does not contain calcium chloride or other potential corroding materials, and may be used in the presence of aluminum or zinc metals. It is compatible with air-entraining agents, water reducers and calcium chloride, but they must be added separately to the mix.

\section{Primary Applications}

- Prestressed concrete

- Concrete requiring water reduction and set time control

- Architectural concrete

- Hot weather concrete placement

\section{FEATURES/BENEFITS}

Plastic Concrete

- Retards setting characteristics

- Improves finishability

- Improves workability

- Reduces water requirements

- Reduces segregation

Hardened Concrete

- Increases strengths

- Improves finished appearance

- Reduces cracking

- Reduces permeability

- Non staining

\section{TECHNICAL INFORMATION}

\section{Perfomance Data}

The following test results were achieved using typical ASTM C 494 mix design requirements, $517 \mathrm{lb} / \mathrm{yd} \mathrm{d}^{3}\left(307 \mathrm{~kg} / \mathrm{m}^{3}\right)$ cement content and similar $( \pm 0.5) \%$ air content.

These results were obtained under laboratory conditions with materials and mix designs meeting the specifications of ASTM C 494. Changes in materials and mix designs can affect the dosage response of EUCON RETARDER 75.
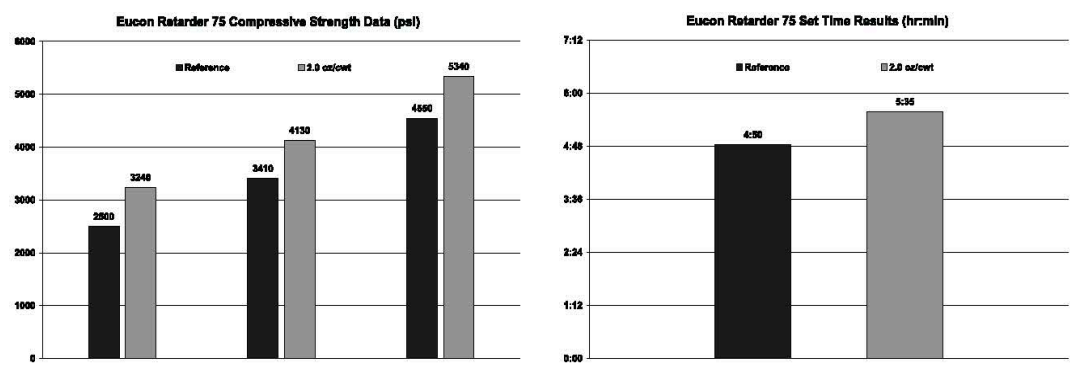
The Euclid Chemical Company

\section{EUCON WR}

WATER Reducing AdMiXtuRE

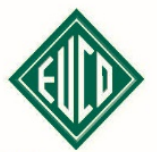

EUCLID CHEMICAL

\section{DESCRIPTION}

EUCON WR is an aqueous solution of refined lignosulfonate which is completely free of any added chloride ions. It is a water-reducing, normal-set admixture for concrete. It provides a more plastic and cohesive mix in the fresh concrete and better durability, reduced shrinkage and less permeability in the hardened concrete.

\section{Primary APPLICATIONS}

- Ready mixed concrete

- Prestressed concrete

- General use concrete

- Precast concrete

\section{FEATURES/BENEFITS}

- Provides easier handling and finishing

- Increases strength

- Provides increased durability

- Reduces shrinkage and permeability

\section{TECHNICAL INFORMATION}

\section{Perfomance Data}

The following test results were achieved using typical ASTM C 494 mix design requirements, $517 \mathrm{lb} / \mathrm{yd}^{3}$ $\left(307 \mathrm{~kg} / \mathrm{m}^{3}\right)$ cement content and similar $( \pm 0.5) \%$ air content.

These results were obtained under laboratory conditions with materials and mix designs meeting the specifications of ASTM C 494. Changes in materials and mix designs can affect the dosage response of EUCON WR.
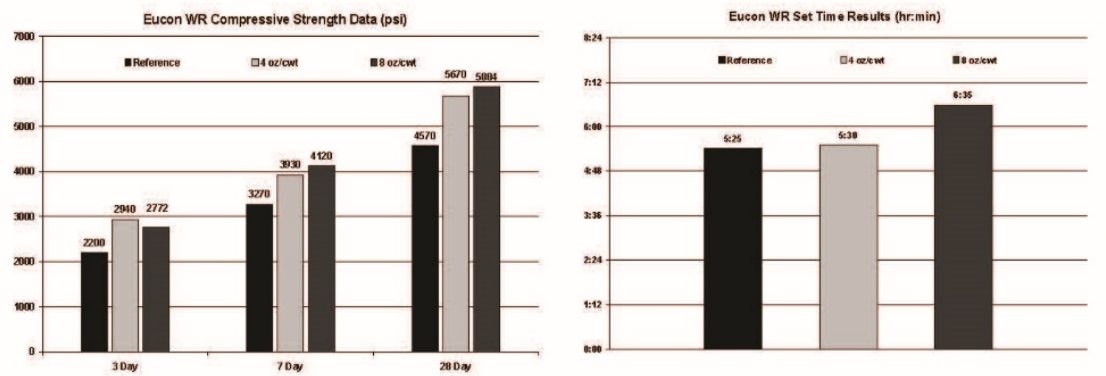
The Euclid Chemical Company

\section{EUCON AWA}

ANTI-WASHOUT ADMIXTURE

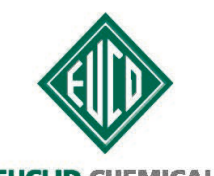

EUCLID CHEMICAL

\section{DESCRIPTION}

EUCON AWA is a ready to use liquid admixture designed to prevent the loss of cement and fine aggregate during the placement of underwater concrete. EUCON AWA is a blend of different powerful ingredients and colloidal agents that act primarily on the water preventing the cement paste from washing out during casting under water. EUCON AWA provides superior slump retention while greatly reducing the environmental impact due to cement wash out in below water applications.

\section{Primary Applications}

- Underwater bridge repair

- Dam repair below the waterline

- Underwater grouting and mortar application

- Damming underground rivers/lakes in mining operations

- Anti-segregation aid for use with lightweight and heavyweight aggregates

- Reduction or elimination of concrete bleed water for use with fast track construction

\section{FEATURES/BENEFITS}

- Minimal environmental impact due to cement washout

- Eliminates the need for expensive de-watering during underwater construction

- Greatly reduces or eliminates concrete bleed water

- Superior slump retention

- Does not effect water demand when slump is maintained

- Easily metered with standard admixture dispensing equipment

\section{TECHNICAL INFORMATION}

Appearance

EUCON AWA is a medium viscosity, dark brown liquid which will not discolor concrete.

\section{PACKAGING}

EUCON AWA is packaged in 275 gal (1041 L) totes, 55 gal (208 L) drums and 5 gal (18.9 L) pails.

\section{SHELF LIFE}

6 months in original, unopened container.

\section{SPECIFICATIONS/COMPLIANCES}

- Meets ASTM C 494 Types S 


\section{The Euclid Chemical Company}

\section{EUCON 37}

High RANge Water RedUCER - SUPERPLASTICIZER

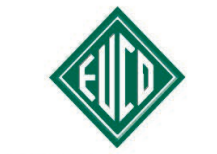

EUCLID CHEMICAL

\section{DESCRIPTION}

EUCON 37 is a high range water-reducing admixture. It may be added to the concrete at the job site or at the ready mix concrete plant. EUCON 37 is formulated to retain plastic consistancy for 30-60 minutes after dosing depending on the initial slumps, dosage rates, and ambient temperature. No chlorides are used in its formulation; consequently, it is recommended for prestressed concrete. It is also compatible with air-entraining agents, waterproofing agents, calcium chloride and many other admixtures; however, each material should be added to the concrete separately.

\section{Primary ApPLications}

- High performance concrete

- General ready mix concrete

- Flatwork and mass concrete

- Heavily reinforced concrete

- Minimum water content concrete

- Low water/cement ratio concrete

- High slump, flowable concrete

\section{FEATURES/BENEFITS}

- Produces low water content and low water/cement ratio concrete allowing higher strengths

- Produces flowing concrete with better than normal strengths

- Aids in concrete placement and reduces labor cost

- When used in precast work with Type I cement will produce the high early strengths

\section{TECHNICAL INFORMATION}

\section{Performance Data:}

The following test results were achieved using typical ASTM C 494 mix design requirements, $517 \mathrm{lb} / \mathrm{yd}^{3}$ $\left(307 \mathrm{~kg} / \mathrm{m}^{3}\right)$ cement content and similar $( \pm 0.5) \%$ air content. These results were obtained under laboratory conditions with materials and mix designs meeting the specifications of ASTM C 494. Changes in materials and mix designs can affect the dosage response of EUCON 37.
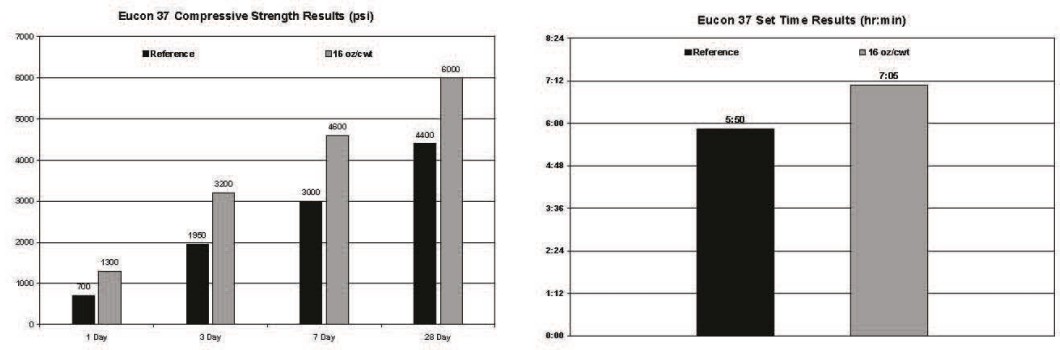


\title{
Appendix F: Water Quality Test Reports
}

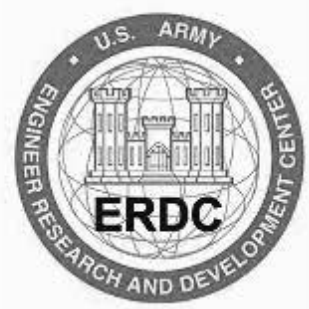

\author{
USACE ERDC-EP-C \\ 3909 Halls Ferry Road \\ Vicksburg, MS 39180-6199
}

12 August 2016

Monica Ramsey

ERDC - Vicksburg (EL)

ERDC, 3909 Halls Ferry Road

Vicksburg, MS 39180

RE: Chapleroi L\&D

Enclosed are the results of analyses for samples received by the laboratory on 25 -Apr-2016. The samples associated with this report will be held for 90 days from the date of this report. The raw data associated with this report will be held for 5 years from the date of this report. If you need us to hold onto the samples or the data longer then these specified times, you will need to notify us in writing at least 30 days before the expiration dates. If you have any questions concerning this report, please feel free to contact me.

Sincerely,

Jenifer Milam For Allyson Holman

Biologist 


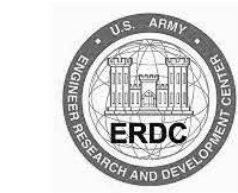

USACE ERDC-EP-C

3909 Halls Ferry Road

Vicksburg, MS 39180-6199

ERDC -- Vicksburg (EL)

ERDC, 3909 Halls Ferry Road

Project: Chapleroi L\&D

Reported:

Vicksburg MS, 39180

Project Manager: Monica Ramsey

12-Aug-2016

WORK ORDER SUMMARY

\begin{tabular}{|c|c|c|c|c|}
\hline Sample ID & Laboratory ID & Matrix & Date Sampled & Date of Work Order \\
\hline 150088 & $6042502-01$ & Water & 25-Apr-2016 & 25-Apr-2016 \\
\hline 150089 & 6042502-02 & Water & 25-Apr-2016 & 25-Apr-2016 \\
\hline
\end{tabular}

The results in this report apply to the samples analyzed in accordance with the chain of custody document. This analytical report must be reproduced in its entirety. 


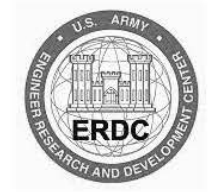

USACE ERDC-EP-C

3909 Halls Ferry Road

Vicksburg, MS 39180-6199

ERDC -- Vicksburg (EL)

ERDC, 3909 Halls Ferry Road

Project: Chapleroi L\&D

Vicksburg MS, 39180

Project Manager: Monica Ramsey

Reported:

12-Aug-2016

\section{Case Narrative}

No issues were experienced during the analysis of Work Order 6042502 unless specified below. 


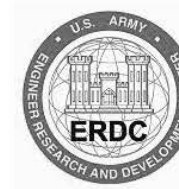

USACE ERDC-EP-C

3909 Halls Ferry Road

Vicksburg, MS 39180-6199

ERDC -- Vicksburg (EL)

ERDC, 3909 Halls Ferry Road

Project: Chapleroi L\&D

Vicksburg MS, 39180

Project Manager: Monica Ramsey

Reported:

12-Aug-2016

Notes and Definitions

U Analyte included in the analysis, but not detected

J Detected but below the Reporting Limit, therefore, result is an estimated concentration.

DET Analyte DETECTED

ND Analyte NOT DETECTED at or above the reporting limit

NR Not Reported

dry Sample results reported on a dry weight basis

RPD Relative Percent Difference

The results in this report apply to the samples analyzed in accordance with the chain of custody document. This analytical report must be reproduced in its entirety. 


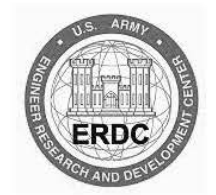

\author{
USACE ERDC-EP-C \\ 3909 Halls Ferry Road
}

Vicksburg, MS 39180-6199

ERDC -- Vicksburg (EL)

ERDC, 3909 Halls Ferry Road

Project: Chapleroi L\&D

Vicksburg MS, 39180

Project Manager: Monica Ramsey

Reported:

12-Aug-2016

150088

6042502-01 (Water)

\begin{tabular}{|c|c|c|c|c|c|c|c|c|}
\hline Analyte & Result & $\begin{array}{r}\text { Detection } \\
\text { Limit }\end{array}$ & $\begin{array}{r}\text { Reporting } \\
\text { Limit }\end{array}$ & Units & Prepared & Analyzed & Method & Notes \\
\hline
\end{tabular}

ERDC-EL-EP-C

\begin{tabular}{|c|c|c|c|c|c|c|c|}
\hline Chloride, filtered & 34.1 & 1.00 & 3.00 & $\mathrm{mg} / \mathrm{L}$ & 28-Apr-2016 & 28-Apr-2016 & EPA 300.0 \\
\hline Sulfate, filtered & 94.8 & 1.00 & 3.00 & $\mathrm{mg} / \mathrm{L}$ & 28-Apr-2016 & 28-Apr-2016 & EPA 300.0 \\
\hline \multicolumn{8}{|c|}{ Metals (Dissolved) by EPA 6000/7000 Series Methods } \\
\hline Iron & 0.0553 & 0.00200 & 0.0400 & $\mathrm{mg} / \mathrm{L}$ & 27-Apr-2016 & 27-Apr-2016 & EPA 6020 \\
\hline \multicolumn{8}{|c|}{ Miscellaneous Physical/Conventional Chemistry Parameters } \\
\hline pH & 7.82 & & & pH Units & $25-\mathrm{Apr}-2016$ & $26-\mathrm{Apr}-2016$ & EPA 150.1 \\
\hline
\end{tabular}

The results in this report apply to the samples analyzed in accordance with the chain of custody document. This analytical report must be reproduced in its entirety. 


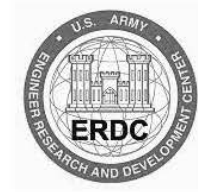

USACE ERDC-EP-C

3909 Halls Ferry Road

Vicksburg, MS 39180-6199

ERDC -- Vicksburg (EL)

ERDC, 3909 Halls Ferry Road

Project: Chapleroi L\&D

Vicksburg MS, 39180

Project Manager: Monica Ramsey

Reported:

12-Aug-2016

150089

6042502-02 (Water)

\begin{tabular}{|lrrrrrrrr}
\hline & & Detection & Reporting & & & & & \\
Analyte & Result & Limit & Limit & Units & Prepared & Analyzed & Method & Notes \\
\hline
\end{tabular}

ERDC-EL-EP-C

Anions by EPA Method 300.0

Chloride, unfilter ed

$\begin{array}{llll}14800 & 20.0 & 100 & \mathrm{mg} / \mathrm{L}\end{array}$

Sulfate, unfiltered

$\begin{array}{llll}\mathrm{ND} & 10.0 & 30.0 & \mathrm{mg} / \mathrm{L}\end{array}$

28-Apr-2016

28-Apr-2016

EPA 300.0

Metals by EPA 6000/7000 Series Methods

Iron

$31.0 \quad 0.00200 \quad 0.0400$

$\mathrm{mg} / \mathrm{L}$

28-Apr-2016

28-Apr-2016

EPA 300.0

Miscellaneous Physical/Conventional Chemistry Parameters

pH

7.71

$\mathrm{pH}$ Units

27-Apr-2016

27-Apr-2016

EPA 6010

The results in this report apply to the samples analyzed in accordance with the chain of custody document. This analytical report must be reproduced in its entirety. 


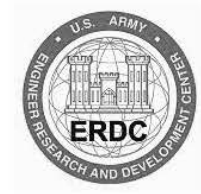

USACE ERDC-EP-C

3909 Halls Ferry Road

Vicksburg, MS 39180-6199

ERDC -- Vicksburg (EL)

ERDC, 3909 Halls Ferry Road

Project: Chapleroi L\&D

Vicksburg MS, 39180

Project Manager: Monica Ramsey

Reported:

12-Aug-2016

Anions by EPA Method 300.0 - Quality Control

ERDC-EL-EP-C

\begin{tabular}{|lrrrrrrrrrrrr}
\hline & & Detection & Reporting & & Spike & Source & & \%REC & & RPD \\
Analyte & Result & Limit & Limit & Units & Level & Result & $\%$ REC & Limits & RPD & Limit & Notes & \\
\hline
\end{tabular}

Batch B605197 - Default Prep GenChem

\begin{tabular}{|c|c|c|c|c|c|c|c|c|c|c|c|}
\hline \multirow{2}{*}{$\frac{\text { Blank (B605197-BLK1) }}{\text { Chloride, filtered }}$} & \multicolumn{11}{|c|}{ Prepared \& Analyzed: 28-Apr-2016 } \\
\hline & ND & 0.100 & 0.300 & $\mathrm{mg} / \mathrm{L}$ & & & & & & & U \\
\hline Chloride, unfiltered & ND & 0.100 & 0.500 & $\mathrm{mg} / \mathrm{L}$ & & & & & & & U \\
\hline Sulfate, filtered & $\mathrm{ND}$ & 0.100 & 0.300 & $\mathrm{mg} / \mathrm{L}$ & & & & & & & \\
\hline Sulfate, unfiltered & ND & 0.100 & 0.300 & $\mathrm{mg} / \mathrm{L}$ & & & & & & & \\
\hline LCS (B605197-BS1) & \multicolumn{10}{|c|}{ Prepared \& Analyzed: 28-Apr-2016 } & \\
\hline Chloride, filtered & 1.91 & 0.100 & 0.300 & $\mathrm{mg} / \mathrm{L}$ & 2.000 & & 95.6 & $80-120$ & & & \\
\hline Sulfate, filtered & 1.97 & 0.100 & 0.300 & $\mathrm{mg} / \mathrm{L}$ & 2.000 & & 98.7 & $85-115$ & & & \\
\hline Sulfate, unfiltered & 1.97 & 0.100 & 0.300 & $\mathrm{mg} / \mathrm{L}$ & 2.000 & & 98.7 & $85-115$ & & & \\
\hline Duplicate (B605197-DUP1) & \multicolumn{4}{|c|}{ Source: $6042502-01$} & \multicolumn{7}{|c|}{ Prepared \& Analyzed: $28-A p r-2016$} \\
\hline Chloride, filtered & 34.0 & 1.00 & 3.00 & $\mathrm{mg} / \mathrm{L}$ & & 34.1 & & & 0.314 & 20 & \\
\hline Sulfate, filtered & 95.3 & 1.00 & 3.00 & $\mathrm{mg} / \mathrm{L}$ & & 94.8 & & & 0.505 & 20 & \\
\hline Matrix Spike (B605197-MS1) & \multicolumn{4}{|c|}{ Source: $6042502-01$} & \multicolumn{7}{|c|}{ Prepared \& Analyzed: 28-Apr-2016 } \\
\hline Chloride, filtered & 85.4 & 0.100 & 0.300 & $\mathrm{mg} / \mathrm{L}$ & 50.00 & 34.1 & 103 & $80-120$ & & & \\
\hline Sulfate, filtered & 149 & 1.00 & 3.00 & $\mathrm{mg} / \mathrm{L}$ & 50.00 & 94.8 & 109 & $85-115$ & & & \\
\hline
\end{tabular}

The results in this report apply to the samples analyzed in accordance with the chain of custody document. This analytical report must be reproduced in its entirety. 


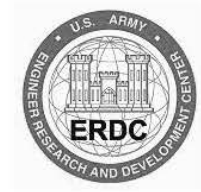

USACE ERDC-EP-C

3909 Halls Ferry Road

Vicksburg, MS 39180-6199

ERDC -- Vicksburg (EL)

ERDC, 3909 Halls Ferry Road

Project: Chapleroi L\&D

Vicksburg MS, 39180

Project Manager: Monica Ramsey

Reported:

12-Aug-2016

Metals (Dissolved) by EPA 6000/7000 Series Methods - Quality Control

ERDC-EL-EP-C

\begin{tabular}{|lrrrrrrrrrrrrr}
\hline & & Detection & Reporting & & Spike & Source & & \%REC & & RPD \\
Analyte & Result & Limit & Limit & Units & Level & Result & $\%$ REC & Limits & RPD & Limit & Notes \\
\hline
\end{tabular}

Batch B605060 - Default Prep Metals

Blank (B605060-BLK1)

Prepared \& Analyzed: 27-Apr-2016

\begin{tabular}{lllll}
\hline Iron & 0.00171 & 0.00100 & 0.0200 & $\mathrm{mg} / \mathrm{L}$
\end{tabular}

LCS (B605060-BS1) $\quad$ Prepared \& Analyzed: 27-Apr-2016

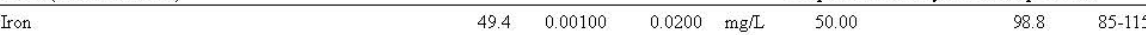

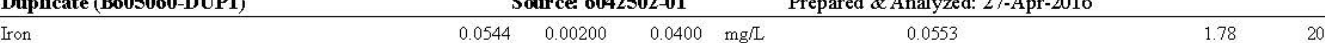

$\begin{array}{lll}\text { Matrix Spike (B605060-MS1) } & \text { Source: 6042502-01 } & \text { Prepared \& Analyzed: 27-Apr-2016 }\end{array}$

\begin{tabular}{|c|c|}
\hline Iron & \\
\hline
\end{tabular}

The results in this report apply to the samples analyzed in accordance with the chain of custody document. This analytical report must be reproduced in its entirety. 


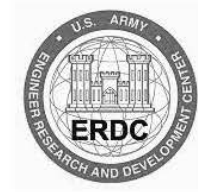

USACE ERDC-EP-C

3909 Halls Ferry Road

Vicksburg, MS 39180-6199

ERDC -- Vicksburg (EL)

ERDC, 3909 Halls Ferry Road

Project: Chapleroi L\&D

Vicksburg MS, 39180

Project Manager: Monica Ramsey

Reported:

12-Aug-2016

Metals by EPA 6000/7000 Series Methods - Quality Control

ERDC-EL-EP-C

\begin{tabular}{|lrrrrrrrrrrrr}
\hline & & Detection & Reporting & & Spike & Source & & \%REC & & RPD & & \\
Analyte & Result & Limit & Limit & Units & Level & Result & \%REC & Limits & RPD & Limit & Notes \\
\hline
\end{tabular}

Batch B605059 - Default Prep Metals

Blank (B605059-BLK1)

Prepared \& Analyzed: 27-Apr-2016

\begin{tabular}{lllll}
\hline Iron & 0.00171 & 0.00100 & 0.0200 & $\mathrm{mg} / \mathrm{L}$
\end{tabular}

LCS (B605059-BS1)

Prepared \& Analyzed: 27-Apr-2016

$\begin{array}{llllllll}\text { Iron } & 49.4 & 0.00100 & 0.0200 & \mathrm{mg} / \mathrm{L} & 50.00 & 98.8 & 80-120\end{array}$

Duplicate (B605059-DUP1)

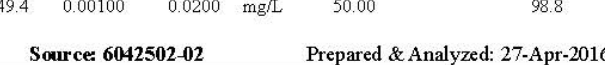

$\begin{array}{llll}31.8 & 0.00200 & 0.0400 & \mathrm{mg} / \mathrm{L}\end{array}$

Matrix Spike (B605059-MS1)

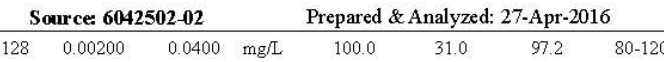

31.0

Iron

The results in this report apply to the samples analyzed in accordance with the chain of custody document. This analytical report must be reproduced in its entirety. 
USACE ERDC-EP-C

3909 Halls Ferry Road

ERDC

Vicksburg, MS 39180-6199

ERDC -- Vicksburg (EL)

ERDC, 3909 Halls Ferry Road

Project: Chapleroi L\&D

Vicksburg MS, 39180

Project Manager: Monica Ramsey

Reported:

12-Aug-2016

The results in this report apply to the samples analyzed in accordance with the chain of custody document. This analytical report must be reproduced in its entirety. 
Items for Project Manager Review

LabNumber

Analysis

Analyte

Exception 


\section{Unit Conversion Factors}

\begin{tabular}{|c|c|c|}
\hline Multiply & By & To Obtain \\
\hline cubic feet & 0.02831685 & cubic meters \\
\hline cubic yards & 0.7645549 & cubic meters \\
\hline degrees (angle) & 0.01745329 & radians \\
\hline degrees Fahrenheit & $(\mathrm{F}-32) / 1.8$ & degrees Celsius \\
\hline feet & 0.3048 & meters \\
\hline gallons (US liquid) & $3.785412 \mathrm{E}-03$ & cubic meters \\
\hline inches & 0.0254 & meters \\
\hline mils & 0.0254 & millimeters \\
\hline ounces (US fluid) & $2.957353 \mathrm{E}-05$ & cubic meters \\
\hline pounds (force) & 4.448222 & newtons \\
\hline pounds (force) per square inch & 6.894757 & kilopascals \\
\hline pounds (mass) & 0.45359237 & kilograms \\
\hline pounds (mass) per cubic foot & 16.01846 & kilograms per cubic meter \\
\hline quarts (US liquid) & $9.463529 \mathrm{E}-04$ & cubic meters \\
\hline square inches & $6.4516 \mathrm{E}-04$ & square meters \\
\hline tons (force) & $8,896.443$ & newtons \\
\hline tons ( 2,000 pounds, mass) & 907.1847 & kilograms \\
\hline tons $(2,000$ pounds, mass) per square foot & $9,764.856$ & kilograms per square meter \\
\hline yards & 0.9144 & meters \\
\hline
\end{tabular}




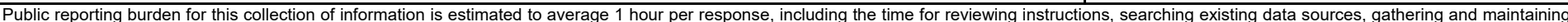

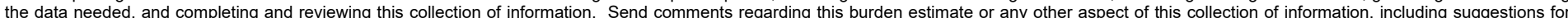

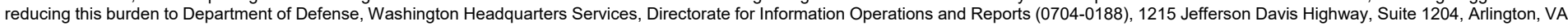

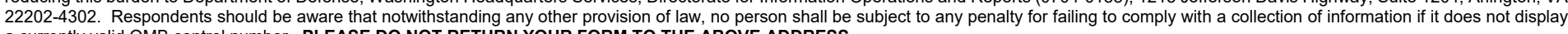
a currently valid OMB control number. PLEASE DO NOT RETURN YOUR FORM TO THE ABOVE ADDRESS.
1. REPORT DATE (DD-MM-YYYY) 2. REPORT TYPE
3. DATES COVERED (From - To)

May 2020 Final

\section{TITLE AND SUBTITLE}

5a. CONTRACT NUMBER

Investigation of Materials for Charleroi Lock and Dam Monongahela River

Reconstruction Project

5b. GRANT NUMBER

5c. PROGRAM ELEMENT NUMBER

\section{AUTHOR(S)}

5d. PROJECT NUMBER

Monica A. Ramsey and Cody M. Strack

5e. TASK NUMBER

5f. WORK UNIT NUMBER

\section{PERFORMING ORGANIZATION NAME(S) AND ADDRESS(ES)}

8. PERFORMING ORGANIZATION REPORT NUMBER

Geotechnical and Structures Laboratory

U.S. Army Engineer Research and Development Center

ERDC/GSL TR-20-20

3909 Halls Ferry Road

Vicksburg, MS 39180-6199

9. SPONSORING / MONITORING AGENCY NAME(S) AND ADDRESS(ES)

10. SPONSOR/MONITOR'S ACRONYM(S)

U.S. Army Corps of Engineers Pittsburgh District

Pittsburgh, PA 15222

11. SPONSOR/MONITOR'S REPORT NUMBER(S)

\section{DISTRIBUTION / AVAILABILITY STATEMENT}

Approved for public release; distribution is unlimited.

\section{SUPPLEMENTARY NOTES}

MIPR W81ET491842462, Lower Monongahela River Navigation System Feasibility Study

\section{ABSTRACT}

The investigation described in this report was conducted for the U.S. Army Engineer District, Pittsburgh as part of a preliminary investigation of cementitious materials and concrete design pursuant to construction of Charleroi Lock and Dam Monongahela River Reconstruction Project. Local materials provided to the U.S. Army Engineer Research Development Center (ERDC) for testing included three different coarse aggregate gradations, two fine aggregate sources, a type II (MH) cement, four fly ash sources, a slag cement, a silica fume, a limestone powder, five admixtures, and two water sources. Aggregate tests consisted of sieve analysis, specific gravity, absorption, materials finer than No. 200, organic impurities, soundness, LA abrasion, clay lumps and friable particles, flat and elongated particles, lightweight particles, and petrography. All cementitious, admixtures, and water-source materials were tested for chemical and physical properties based on appropriate specifications. In addition, four mixture proportions developed by the ERDC for this project in 2005 were scaled to determine the early stiffening of mortar, freezing and thawing, and heat of hydration. This report presents the material characteristic results determined by laboratory testing in accordance with American Society for Testing and Materials procedures or regulating specification criteria.

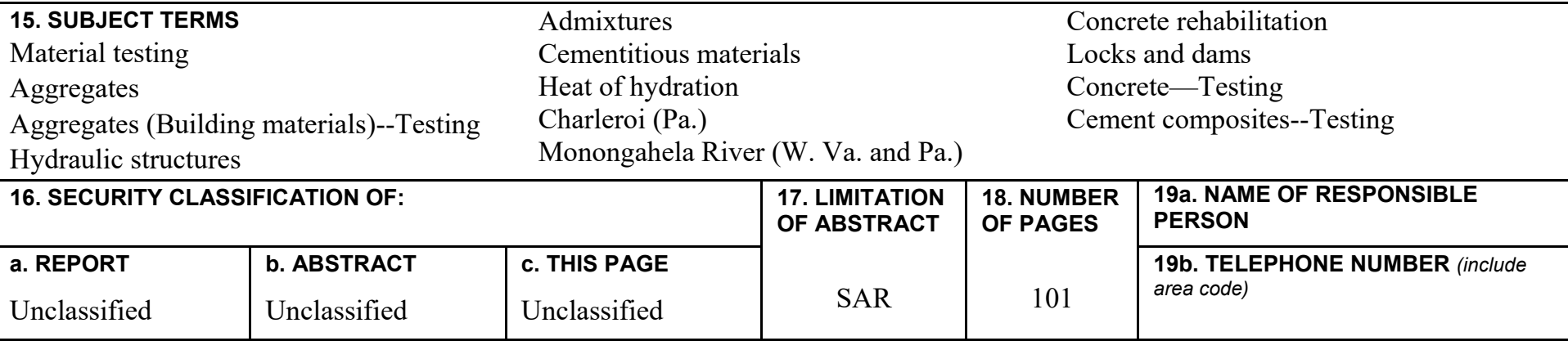

